Claremont Colleges

Scholarship@ Claremont

2012

\title{
Africa's Unresponsive Democratization: the Relationship between Regime Type and the Quality of Life in Africa
}

Caryn Anne Peiffer

Claremont Graduate University

\section{Recommended Citation}

Peiffer, Caryn Anne, "Africa's Unresponsive Democratization: the Relationship between Regime Type and the Quality of Life in Africa" (2012). CGU Theses \& Dissertations. Paper 29.

http://scholarship.claremont.edu/cgu_etd/29

DOI: $10.5642 /$ cguetd $/ 29$

This Open Access Dissertation is brought to you for free and open access by the CGU Student Scholarship at Scholarship @ Claremont. It has been accepted for inclusion in CGU Theses \& Dissertations by an authorized administrator of Scholarship @ Claremont. For more information, please contact scholarship@cuc.claremont.edu. 
Africa's Unresponsive Democratization: the Relationship between Regime Type and the Quality of Life in Africa

\author{
by \\ Caryn Anne Peiffer \\ Claremont Graduate University \\ 2012 \\ (C) Copyright Caryn Peiffer, 2012 \\ All rights reserved.
}




\title{
Approval of the Review Committee
}

This dissertation has been duly read, reviewed, and critiqued by the Committee listed below, which hereby approves the manuscript of Caryn Peiffer as fulfilling the scope and quality requirements for meriting the degree of Ph. D. of Political Science.

\author{
Pierre Englebert, Chair \\ Pomona College \\ Professor
}

\author{
Jennifer Merolla \\ Claremont Graduate University \\ Associate Professor \\ Yi Feng \\ Claremont Graduate University \\ Professor
}




\begin{abstract}
Africa's Unresponsive Democratization: the Relationship between Regime Type and the Quality of Life in Africa

by

Claremont Graduate University: 2012
\end{abstract}

Scholars and policy makers alike argue that leaders of democracies should find it in their interest to provide high levels of social services due to a fear of being voted out of office. Yet, I find that Africa's newer democracies provide levels of social services strikingly similar to what the continent's existing non-democracies supply. This dissertation seeks to explain why this is the case.

I start by exploring the determinants of Africa's most recent wave of democratization, and find that much of Africa's 1990s democratic wave can be attributed to changes in foreign circumstances rather than from pressures from domestic democratic movements. I argue democratization has become disassociated with social services on the continent because of this exogenous nature of political liberalization. Rather than institutionalizing electoral incentives to provide social services, leadership of exogenously derived democracies become principally accountable to the foreign actors for whom political change was meant to appease. However, foreign actors are effectively unable and unwilling to demand political reforms that will institutionalize a more responsive democracy. This dynamic threatens any electoral incentive a ruling party might have to produce higher levels of social services. I test this argument quantitatively and find support for the notion that exogeneity of political change has dampened the impact that democratization has had on social service delivery in Africa.

Additionally, through in-country, qualitative fieldwork I examine how citizens demand social services and how the government responds to such demands in Zambia, a country whose democratization was heavily influenced by foreign pressure. There, I found that while there were 
important initial strides made by Zambia's post-transition government to institutionalize a higher level of responsiveness in social services, later erosions in Zambia's checks and balances undermined these gains. Finally, using Afrobarometer's cross-national survey data, I explore what impact foreign influenced democratization has on citizens' attachment to and satisfaction with democracy. I find that exogenously derived democratization has a small negative impact on people's attachment to democracy and satisfaction with the way democracy works in their country. I conclude by discussing some of the policy implications of these findings. 


\section{Acknowledgements}

First and foremost, I want to thank the chair of my dissertation committee, who I was lucky enough to also have as an advisor and co-author, and who will always be a friend, Pierre Englebert. I will take as many lessons in life from Pierre as I will lessons in research. The joy and enthusiasm he has for his research is contagious and was always motivational for me, even during the toughest times of the Ph.D. pursuit. I will be forever grateful for the laughs we shared, his perfectly timed encouragement, and, in general, having the chance to be his student.

I also want to thank my two other committee members, Jennifer Merolla and Yi Feng. I am grateful to both of them for their time spent on reviewing and re-reviewing my dissertation. Their insightful questions and comments gave me a needed outsider-to-Africa's perspective, and pressed me to continually improve the overall project. To Jenn, I am also thankful for the chance to serve as her research assistant for so many projects, co-author and our friendship. Her mentorship taught me many lessons that cannot be picked up in a classroom. I am also grateful to Dr. Dean McHenry, Jr. Although he retired before I started my dissertation, the conversations we had and his encouragement to do field work ultimately shaped the research path I pursued.

I am grateful to several in Zambia and Botswana, who helped me while I was there doing fieldwork. My research benefitted tremendously from the time spent and conversations had with Stuart Nsana, Dr. Canisius Banda, John Kalokoni, Fredrick Mutesa, Claire van der Kleij, Dr. Rueben Lfuka, Dr. Peter Lologhi, Benson Bwalya, Mufalo Mbinji, and Dr. Felix Phiri. Additionally, I am thankful to Dr. David Sebudubudu and the University of Botswana for taking me under the department's wing and to Dr. Sheldon and Gudrun Weeks for their hospitality (and great wine) in Botswana. I also gratefully acknowledge the funding source that made my Ph.D. dissertation work possible: the Claremont Graduate University Dissertation Grant.

Without the friendships gained during this Ph.D. program, I am convinced I would not have 
been able to finish. So, I will be forever grateful to the summer spent with Linda Alvarez in India, where our friendship was born. While we learned a lot of the "how-nots" of fieldwork that summer, in Linda I also found a development-oriented ally and fast friend. My work has advanced because of her honest feedback and my moral has benefitted from her constant support and ridiculous humor. Additionally, I am so thankful to my first published co-author and good friend, Constantine Boussalis. Without him, I am not sure I would have ever gotten over the qualifying exams hurdle, and without his editorial nit picking, I would not have nearly advanced as much as a writer. I am also thankful for my good friend, Danyel Vargas. She always joined me, usually with margaritas, in celebrating the smallest of milestones along the way. Her support of me throughout this entire process was unwavering; something I hope I have returned and continue to provide for her as she finishes up her Ph.D. To all of them, I thank you for reviewing sections of papers and this dissertation, being available and willing to entertain abstract and somewhat nonsensical research queries, listening to my fieldwork mishaps, and most of all, for every laugh we shared.

Lastly, I would like to thank my family for all their encouragement. Specifically, for my parents who raised me with an expectation that I always reach for my full potential, encouraged my adventurous spirit, and never lost patience with my seemingly never-ending pursuit of this degree. For my brother, sister, nieces, nephew, brother-in-law and sister-in-law, who understood when I was swamped with Ph.D. obligations and did not ask too many times "when are you going to be done?" And for my encouraging and loving partner, Olly, whose support during fieldwork and the final stages of this Ph.D. was pivotal, and with whom I am so excited to share the next phase in life. Thank you. 


\section{Table of Contents}

Chapter One: Democratization and Social Services in Africa 1

Democracies, Social Services and Quality of Life 3

A Review of Evidence 6

Africa's Social Services in a Comparative Perspective 9

Puzzle: Democratization and Social Services in Africa, 1990 to 2005

Chapter Two: Determinants of Democratization and Regime Consolidation in Africa 23

Transitions and Consolidations $\quad 25$

Democratization Theory and Africa 31

Theoretical Argument $\quad 39$

Extraversion Portfolios $\quad 40$

Vulnerable Extraversion Portfolios and Initial Democratization 42

Vulnerable Extraversion Portfolios and Democratic Consolidation 45

Making Sense of Hybrid Consolidations 49

Empirical Evidence $\quad 53$

$\begin{array}{ll}\text { Transitions } & 54\end{array}$

Consolidations $\quad 57$

$\begin{array}{ll}\text { Conclusion } & 60\end{array}$

Chapter Three: Exogenous Political Change and Government Responsiveness 62

Exogenous Democratic Change and Responsive Leadership 63

Donors' Role in Establishing a Responsive Government 65

Domestic Political Environment in Exogenously Derived Democracies $\quad 70$

Measuring the Exogeneity of Political Change 76

Analyses of Exogenous Democratization and the Quality of Life 92

Robustness Checks with Alternative Coding of Ambiguous Cases 102

$\begin{array}{ll}\text { Conclusion } & 108\end{array}$

Chapter Four: Multiparty Politics and Social Service Delivery in a Hybrid Regime, Zambia 110

Becoming a Multiparty Hybrid 113

Replacing Single Party Rule with Multiparty Competition 113

$\begin{array}{ll}\text { Hybridization of the Zambian Democracy } & 117\end{array}$

Social Services and Political Change in Zambia 124

Regime Change and Local Government $\quad 125$

Expanding a Central Influence in Local Level Social Services 128

$\begin{array}{ll}\text { Keeping the Purse at the Center } & 131\end{array}$

A Low Capacity Local Government 134

Zambian Voters 136

$\begin{array}{ll}\text { Alternatives in the Party System } & 138\end{array}$

Conclusion

Chapter Five: Exogenous Democratization and Bottom-up Democratic Consolidation 143

Support for and Satisfaction with Democracy and Exogenous Democratization $\quad 145$

Possible Negative Impact of Exogenous Democratization 151

Data, Variables, and Estimation Strategy 152

$\begin{array}{lr}\text { Afrobarometer } & 152\end{array}$ 
Dependent Variables: Support for and Satisfaction with Democracy

Controls Used in Support for Democracy 155

Controls Used in Satisfaction with Democracy 158

Results

159

Conclusion

Conclusion: Africa's Unresponsive Consolidation or a Way Forward? 170

Unresponsive Democratization and Foreign Democracy Promotion 173

The Endogenization of an Exogenously Derived Democracy 175

Ghana's Exogenously Influenced Democratization 175

$\begin{array}{ll}\text { Signs of Endogenization } & 176\end{array}$

$\begin{array}{ll}\text { Ghana's Party Roots as a Source of Endogenization } & 179\end{array}$

Conclusion

Appendices $\quad 182$

Appendix I: Data Sources and Measurement for Chapter 2 Analyses 182

Appendix II: Summary Statistics of Data Used in Chapter $3 \quad 183$

Appendix III: The Exogeneity of Transitions by Afrobarometer Sample, Chapter 5184

Appendix IV: Details on the Question Wording and Construction of Control 185

Variables Used, Chapter 5

Works Cited

192-211 


\section{Chapter One: Democratization and Social Services in Africa}

Prior to the end of the Cold War, most of Africa was a bastion of authoritarianism and repression. However, by the mid-1990s more than thirty regimes had been persuaded by foreign aid donor-countries and domestic actors to hold multiparty elections. Democracy's "third wave" had surprised many by sweeping across the continent. Richard Joseph observed that because Africa lacked the conditions that most believed to be standard pre-requisites to democracy, like a strong middle class, sufficient capitalist economy, and civic culture, the potential for democracy to take root in Africa was written off by notable comparative democracy specialists, like Samuel Huntington and Robert Dahl, as well as established Africanists, like Crawford Young and Michael Bratton (Joseph 1997: 363-364). And probably at least in part because of the absence of many of these "prerequisites," the depth of the democratic changes that occurred varied significantly across the continent. While many regimes have institutionalized regular and multiparty elections, some "transitions" were halted before they ever truly materialized. Togo, Gabon, and Equatorial Guinea are just a few examples where regimes announced multiparty elections only to later repress their possible opposition and steal victory at the polls. Several other regimes have continued to hold multiparty elections, but have undermined a deepening of the democratic experiment by rigging the political playing field. A particularly egregious example was in Zambia, where, prior to the second presidential election, the Chiluba regime, which had gotten to power carried by a genuinely

democratic tide, changed the presidential candidacy rules to effectively make his biggest competitor, Kenneth Kaunda, ineligible to run.

Africa's democratic progression might be easy to understate, given that most of its new democracies have failed to resemble "consolidated" or "liberal" democracies. However, optimism might come from the fact that a majority of the regimes that had multiparty elections after the end 
of the Cold War institutionalized the process (Posner and Young 2007). Sustained improvements in civil liberties also mark another indicator of progress. According to Freedom House, the region's strongest democratizers like Mali, Benin, Cape Verde, Malawi, Sao Tome and Principe, and Seychelles, all of which had low civil liberty scores in 1989, were at the other end of the spectrum by 1995 and have remained there since. In fact, in 22 of the continent's new democracies a positive shift, of some size, in civil liberties and political rights is observed over the same period.

These positive shifts in democracy levels confronted scholars, policy makers, and citizens with as many questions about the source of the change as it did with questions about how these changes would impact the quality of life, stability, economic trajectories, and state capacity on the continent. While, at a minimum, multiparty elections offer people a say in who will run their government, several felt that democracy's effects would ripple in other directions. For example, many Africans expected that economic development would accompany democratic change (Bratton and Mattes 1999). Hopes were also raised in some policy circles that peaceful democratic competition could manage and replace conflict in socially divided countries (see Paris 2004: 44 for examples). UN peacekeeping operations often viewed the holding of elections as the final stage in efforts to transition a country away from violent conflict to peaceful politics (Sisk and Reynolds 1999: 1).

But one of the most widespread and basic expectations of democratization was that political liberalization would institutionalize responsive governments. It is a foundation of democratic theory and a legitimate aspiration of citizens in democracies that their leaders will be more inclined than their authoritarian counterparts to provide social services, like healthcare and education, because of their fear of being voted out of office for not doing so (Deacon 2003; Lake and Baum 2001; Bueno de Mesquita et al. 2003; Ghobarah, Huth and Russett 2004; Meltzer and Richard 1981). What is the empirical record in this respect? Are Africans in countries that have progressed democratically living 
a higher quality of life than their counterparts in countries where regimes have stayed authoritarian? Beyond voting regularly in multiparty elections, how has the democratic progress impacted the material lives of Africa's new voters? To my knowledge, these questions have not been addressed by previous literature ${ }^{1}$ and are at the core of this dissertation.

This chapter lays the stage for my investigation. In order to establish a comparative benchmark of what we might expect to find in Africa, I begin with a review of the academic literature on the relationship between democratization and social service provision. Next, I draw an empirical sketch of the continent's comparative performance on social service and quality of life indicators. Two trends emerge: while the continent performs relatively badly on average, there is in fact a tremendous amount of variation across countries. In the following step, I inquire whether this variation can be explained by variations in levels of democracy and in patterns of democratization, the core question of my research. I reproduce econometric models used by others in other contexts to test for the presence of a link between social services and democracy. Paradoxically, while such a link has been well established elsewhere, I find that Africa's "third wave" has not correlated with a rise in social services. This is the central puzzle that the rest of the dissertation seeks to solve.

\section{Democracies, Social Services and Quality of Life}

The quality of life for many around the world rests on their access to goods that are usually provided by the state, such as access to clean water, education and healthcare. When states provide these services they invest in their nation's development and capacity to engage in the international

\footnotetext{
${ }^{1}$ David Stasavage's (2005) work might come closest, as it examined the relationship between education spending and the level of democracy in Africa. However, that research still does not directly address whether the change in democracy has impacted a change in social service delivery. Also, Stasavage (2005) limits his analyses to expenditures and not outcomes and only to education and not a suite of social services. As I point out later, focusing on expenditures may hit on a different question than whether democracy is responsive.
} 
economy. The question of whether or not democracies are better suited than authoritarian regimes to provide these services has been at the center of many analyses (Nelson 2007).

For those who argue that democratic governments are better at social service provision than their non-democratic counterparts, the rise to and maintenance of political office through competitive elections is the primary mechanism which binds democratic leadership to social service provision (Ross 2006; Nelson 2007; Deacon 2003; Lake and Baum 2001; Bueno de Mesquita et al. 2003; Ghobarah, Huth and Russett 2004). ${ }^{2}$ Through democratic elections, voters have the opportunity to either sanction or reward incumbent's governing performance and/or select policy makers that they perceive will work in their own interest (Fearon 1999). As a result, democratic leadership should be incentivized to act in the public interest for fear of being voted out of office (Barro 1973).

Yet, the incentive to redistribute state resources to secure the necessary support to maintain political office is not unique to democratic leadership. What is assumed to differ in democracies is the audience that redistribution is targeted to. Autocrats generally fear a loss of power through force from specific sectors of the elite, and redistribute state resources specifically to these elites. In this manner, they reward loyal supporters or co-opt possible opposition groups. This co-option tactic is extremely limited in its utility for democratic leaders. Democratic leaders remain in power only by being re-elected by a large percentage of people, ${ }^{3}$ thus strictly rewarding elites may hinder their chances of being re-elected. Instead, the theory goes, democratic leaders find it in their interest to

\footnotetext{
${ }^{2}$ Sen's (1999) work on press freedom and responsive regimes also highlights another mechanism through which democratic governance might impact social service performance. Sen (1999) argued that democracies are more effective than autocracies at broadcasting information from the people to the government, due to a freer press. A freer press can embarrass the government by publicizing facts of gross inequalities or extreme injustices, which would pressure action from the center.

${ }^{3}$ Depending on the institutional and party make-up within a polity, democratic leaders can garner a minority of the vote and secure their position in office. Arguably, however, they still have to capture the support of a larger group of people than autocratic regimes.
} 
redistribute state resources in a form that will please as many prospective voters as possible (Bueno de Mesquita et al. 2003).

The theory that links democracy to social service provision not only must take account of the re-election ambitions of politicians, but also of the preference of voters. It assumes that voters will be in favor of the redistribution of state resources through broad based public goods, and be willing to sanction elected officials if they do not enact such policies. Africa's relatively high levels of income inequality and poverty may bring particular relevance to this point. Meltzer and Richard's (1981) work illustrates that in countries with high levels of poverty and income inequality, politicians are more likely to provide redistribution in the form of broad based social services. Extending Downs's (1957) theorem, they argue that, in the context of high levels of inequality and widespread poverty, the "median voter" has a lower income level than the mean income in the country. She is thus most likely to benefit from increased access to social service delivery and will favor such policies, even if they come at the expense of higher taxes on wealthier co-nationals.

However, other factors might undermine Meltzer and Richard's (1981) expectation in Africa. The pervasiveness of neopatrimonial politics in Africa, for example, has been argued to decrease citizens' expectations that the state should provide broad serving public goods. A neopatrimonial system is characterized by public officials offering personal favors (like public sector jobs, licenses, contracts and/or projects) in return the mobilization of political support. Thus, in this system, the maintenance of political authority is essentially reliant much more upon doling out patronage then it is on ideology or even the law (Bratton and van de Walle 1994: 458; Jackson and Rosberg 1984;

Chabal and Daloz 1999). As Michael Bratton (1992: 93) argues, authoritarianism and neopatrimonialism may have bred a passive and/or a "patrimonial political culture" wherein people come to perceive that their own access to state resources will come only from their ability to draw upon personal ties with powerful political officials. Put differently, the effects of living for decades 
under authoritarian rule and within political systems based upon patron-client relationships may have affected Africa's new democratic citizens' view of the role of the state and their own vote (van de Walle 2003). In political systems dominated by clientelism, voting is less about providing mandates on policy platforms than about exchanging votes for material rewards from relatively more powerful patrons running for office (van de Walle 2003: 312).

In addition, a history of entrenched authoritarianism may have impacted the extent to which citizens are willing to interact with the state or demand responsiveness from their elected officials; norms created in such environments might reinforce loyalty to political leaders, regardless of their performance in providing social services (Gyimah-Boadi 1996; Bratton 1994: 9). Finally, ethnic considerations are also likely to blur voting motivations in several African countries (Bates 1983; Horowitz 1985; Young 1976; Dowd and Driessen 2008; Eifert, Miguel, and Posner 2010). Given a common perception that only a co-ethnic will protect one's interests (Habyarimana et al. 2009), voters might prefer a co-ethnic even when tangible benefits are not likely to result from such a vote (van de Walle 2003: 313; Keefer and Khemani 2005). All these mechanisms would then conspire to create a structure of unaccountable democracy: when voters do not use their vote to sanction or reward social service providers, the electoral accountability linkage between democracy and higher social service provisions cannot be reliably counted upon. Yet, although several scholars have indeed called attention to the possibly different political logics of the functioning of African democracies, there has so far been no systematic testing of whether the relationship between democracy and social service provision is robust to the African context. I turn to this question next.

\section{A Review of Evidence}

Even outside of Africa, the cross-national evidence on whether democratic governance impacts social service provisions is somewhat mixed. Scholars have analyzed the relationship 
between democracy and expenditures on social service programs, quality of life, or social service outcomes. Several have found that, holding all else equal, democracies in various settings do in fact spend more than autocracies on social services (Rudra and Haggard 2005; Bueno de Mesquita et al. 2003; Przeworski et. al. 2000; Avelino, Brown and Hunter 2001; Brown and Hunter 1999; Huber, Mustillo and Stephens 2004; Ghobarah, Huth, and Russett 2004; Nooruddin and Simmons 2009; Stasavage 2005). Only Boix (2001) finds that in poorer countries, regime type has no effect on public goods expenditures. But the record is less clear when it comes to outcomes. As Nelson (2007:80) remarks, "Better outcomes also require reallocating resources and institutional reformschanges in sector organization, administration, and incentive systems," which increased expenditures alone do not guarantee. Examining the effects of health expenditure allocation and health outcomes, Mcguire (2006) failed to find a robust relationship. Instead, he argued that the main explanatory variable in determining health outcomes was the coverage and provision of services. Thus, if expenditures were raised but people were not seeing an increase in services and hence markedly improved outcomes, they might still be inclined to punish their leaders at the polls. For this reason, examining the relationship between outcomes and regime type is more appropriate.

While several scholars have found a positive link between democracy and public good outcomes, the evidence at this level is certainly more mixed than with expenditures. Some have found that democratic governance is associated with higher levels of primary and secondary school enrollment, life expectancy, doctors per capita, hospital beds per capita, access to clean water and improved sanitation, immunization coverage, literacy, and lower infant mortality rates (Rudra and Haggard 2005; Bueno de Mesquita et al. 2003; Deacon 2003; 2009; Brown 1999; Frey and Al-Roumi 1999; Shandra et al. 2004; Baum and Lake 2003; Lake and Baum 2001). Others, however, have failed to find such an association. Specifically, Ross (2006) and Shandra et al. (2004) find no relationship 
between democratic governance and infant mortality rates, and Ross (2006) fails to find that democracy has an impact on maternal mortality rates.

These mixed findings may be explained by variations in cases selected, control variables, and time frames used. Such variations are more than mere methodological discrepancies, however, as they might be picking up differences among the democracies they examine. In this respect, Keefer (2007) argues that the age of democracy within a country may differentiate those democracies that are likely to provide high levels of social services from those that are not. From a large sample of developing and developed democracies, he finds that younger democracies are more corrupt, exhibit less rule of law, have lower levels of bureaucratic quality and secondary school enrollment, and have more restrictions on the media. Younger democracies, he argues, are more likely to suffer from a "low credibility" political environment, wherein political competitors are unable to "make credible promises to citizens about broad public policies" (Keefer 2007:805) because of the little time they have had so far to establish themselves as credible actors. In a low credibility political environment, the political incentives to provide public goods or to campaign on the promise of public goods are weak. Instead, in such an environment, the incentives to provide private or targeted goods to feed into established clientelist networks to secure political support are relatively stronger (Keefer 2007:806).

Associating the age of democratic rule to the provision of social services or the likelihood of political actors relying on clientelist networks imposes a somewhat deterministic question: as a democracy ages, should we expect that politicians will be viewed as more credible in their policy promises, and resort less to targeting resources towards clientelist networks? Indeed, as Keefer (2007) acknowledges, "the acquisition of political credibility is not inevitably correlated with age. Building up a policy reputation with broad groups of voters is expensive and politicians may prefer to use patrons. If patrons are cheap enough, politicians may postpone indefinitely the decision to 
invest resources in directly convincing large segments of the voting population of their credibility" (806).

However, this argument fails to account for a couple issues. First, a low credibility environment might be endogenous to the fact that the regime is newly democratic, and not a simply a product of its democratic youth. Put differently, the fact that these countries had not become democratic before might be a function of a pre-existing low credibility environment. Second, Keefer fails to address under what circumstances new democracies can and will break from patronage based low credibility equilibrium. Without doing so, he weakens any association age might theoretically have with the persistence of a low credibility environment .

Thus the question remains of what the age of a democracy might be capturing. The paradox of age might be approximating another causal relationship altogether, as nations that democratized in the post Cold War era, or the relatively "younger" democracies share several features. Many regimes, and especially in Africa, that took steps to democratize during this period received an inordinate amount of foreign pressure to do so. As I argue later, democratic change rooted more in foreign and less in domestic pressures may have a dampening impact on the development of accountability mechanisms.

\section{Africa's Social Services in a Comparative Perspective}

Negative generalizations about the quality of life and governance in sub-Saharan Africa are common. Life in Africa is often portrayed to be rife with the perils of abject poverty and vulnerable to the dangers of political instability (Stith 2005). While most aggregate regional comparative statistics reinforce these stereotypes, it is the tremendous variation of quality of life in the region that confronts us with a more complex picture of government performance on the continent. 
Figures 1 and 2 illustrate the provision of various education and healthcare-related social service by region. Almost across the board, Sub-Saharan Africans have the worst access to social services and the lowest quality of life. Indeed Africans are less likely to be literate, get a primary school education, have access to clean water and sanitation, and are more likely to live a shorter life, be undernourished and die as an infant. In fact, only in immunization rates does Africa come second to last (and this is as much a reflection on the provision of this service by donors than on any intrinsic performance by African governments).
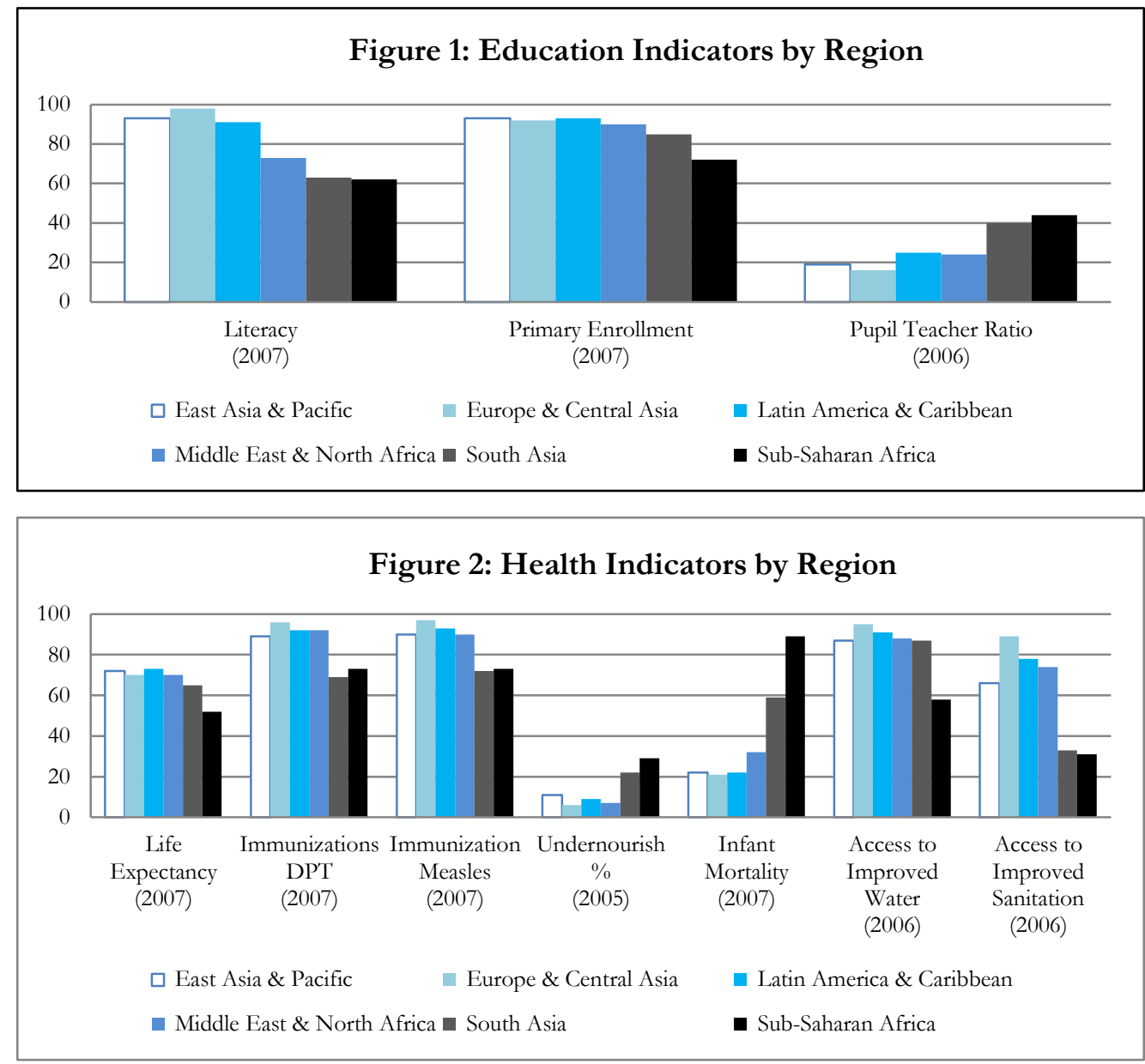

Yet, it would be a mistake to interpret this aggregate performance as representing a homogeneous situation across the continent. Indeed, in countries like the Seychelles, primary school 
enrollment rates are $99 \%$; in Botswana, $96 \%$ of the population has access to "improved water sources;" and Mauritius boasts a life expectancy above 70 years. ${ }^{4}$ In figures 3 and 4 , I compare the standard deviations of each indicator across regions. While Africa does not have the highest degree of variation in all indicators, it has either the highest or the second highest in eight out of the ten.
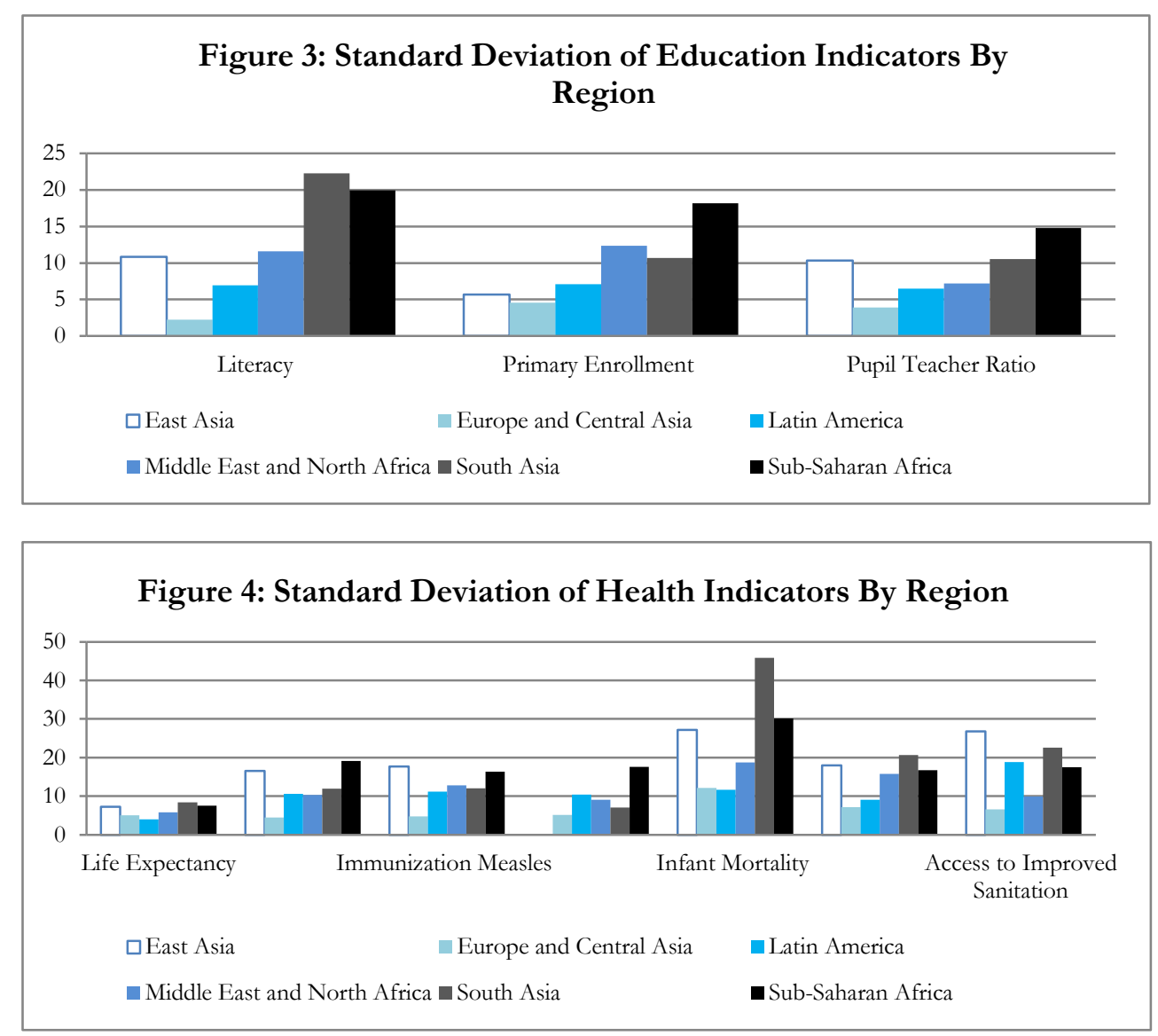

+ data for all four tables is taken from the World Bank's Development Indicators database.

Hence, while Africa performs poorly on average with respect to social service delivery and quality of life, there is immense variation within the region. While the extent of Africa's variation is somewhat unavoidable, given the large number of countries it holds, these descriptive findings still

\footnotetext{
${ }^{4}$ These figures are for 2005 (most recent) from the World Banks Development Indicators
} 
beg the question: what accounts for divergent trends in social service provisions and quality of life on the continent? Why is it that some Africans live longer, healthier and more enriched lives than others? Can this variation be accounted for by the continent's equally large variation in regime type?

\section{Puzzle: Democratization and Social Services in Africa, 1990 to 2005}

While several authors have argued that democracies are better suited to provide a higher quality of life and better social service coverage, others have doubted that this relationship can apply in the African context where several variables, like neopatrimonialism, the legacy of authoritarianism, and the salience of ethnicity, may prevent democratization from returning social service dividends (see supra). These claims have not been empirically tested, however, and a superficial survey of the continental variations in levels of democracy and of social services suggests that the question deserves greater scrutiny. Is African democracy likely to promote higher quality of life and better social services? Has the post-1990 wave of African democratization contributed to improvements in social services?

In this section, I examine the relationship between democratization and changes in social services and quality of life by running a series of cross-sectional Ordinary-Least-Square regressions. Changes in various social service and outcome indicators from 1990 to 2005 are the dependent variables, and change in a country's Freedom House score is the primary independent variable of interest. ${ }^{5}$ What I test here is whether a country's change in democracy score is significantly and positively related to the change in various social service and quality of life outcomes.

I used different dependent variables for a couple of reasons. First, as Kramon and Posner (2010) point out, regimes might perform in drastically different ways across various types of social

\footnotetext{
${ }^{5}$ I used the average between the civil liberties and political rights scores. Also, the original Freedom House scores were changed to be more intuitive. Originally, they are coded so that the largest score (7) is the smallest level of freedom or democracy. I subtracted these scores by 8 to obtain a more intuitive scale where large numbers reflect a more free democracy. Therefore, the change in Freedom House scores are now intuitive so that positive change reflects a move away from undemocratic rule towards democratic rule.
} 
services. For example, a regime may use some social services to reward clientelist networks, but distribute other services more evenly. If there are systematic trends across the continent regarding the motives that regimes use to distribute a certain good, studying democratization's effect on just one indicator might not uncover the entire picture of the relationship I am after. Additionally, if change in democracy levels has an effect with most indicators, we can be more confident in the robustness of the relationship.

African data on social service provisions and outcomes are severely limited, however. Many indicators that approximate different dimensions of the quality of life are spotty in terms of country and, especially, temporal coverage. Yet, many indicators have at least some data available for two common time frames: around 1990 and 2005. Using data from these two periods allows me to approximate a time prior to the democratization wave (1990) and one after the democratization wave seems to have reached an equilibrium (2005). Even so, these indicators still lack coverage of the most troubled or closed regimes, like Somalia and more recently, Zimbabwe, a problem that is more starkly observed in 1990 than in 2005. These limitations force me to focus on five indicators which have sufficient observational coverage to run basic analyses and represent both health and education related measures. They are:

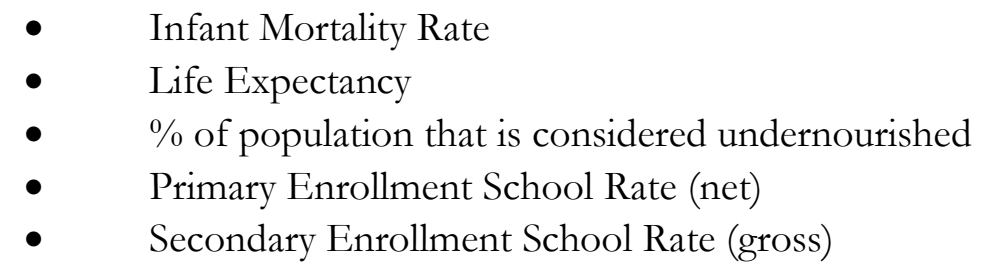

I control for the effects of other plausibly important variables that would either help or impede a government in providing social services. First is GDP per capita which approximates a country's wealth and ability to self-fund social service delivery. I use an average of GDP per capita for the country over the entire period (1990-2005) because using any single year might capture a 
particularly high or low point in the economy. Next I include the percent of the population that lives in an urban area to account for the fact that an urbanized population might facilitate a government's job in delivering services. In urbanized countries a higher percentage of the population will be within one specific area where infrastructure is likely to be more developed. Again, I use the average of this measure. Third, I control for the size of the country to account for the difficulty that larger countries would have in providing social services to their citizens (Herbst 2000). This control is especially important in Africa where large countries like the Sudan and the DRC co-exist with small countries like Lesotho and Cape Verde. I also use average population for a similar reason: governments in more populous countries might have a more difficult and expensive task at providing services. Finally, I control for whether the country experienced a civil war from 1985 to 2005, as such conflicts would have negative effects on political stability, government capacity and infrastructure; all of which are likely to decrease a government's ability to provide social services. Aside from this latter variable, my control variables replicate those used in Lake and Baum's (2001) analyses of social service provisions. ${ }^{6}$ Additionally, because my dependent variable measures change, I control for the initial level of the dependent variable to capture the fact that nations performing well on these indicators initially would have less room for improvement. In the table 1 , I report a summary of the change in democracy level's effect on the change in the various quality of life indicators.

Table 1: The Relationship between Change in Democracy and Change in Quality of Life

\begin{tabular}{|c|c|c|c|c|c|}
\hline & $\Delta$ Democracy Coefficient & P-value & $\mathrm{N}$ & $\mathrm{R}^{2}$ & F-test \\
\hline$\Delta$ Infant Mortality Rate & -0.37 & 0.818 & 47 & 0.26 & 0.08 \\
\hline$\Delta$ Life Expectancy & 0.36 & 0.577 & 47 & 0.27 & 0.07 \\
\hline$\Delta \%$ Undernourished & -1.44 & 0.336 & 42 & 0.23 & 0.19 \\
\hline$\Delta$ Primary Enrollment (net) & 0.94 & 0.477 & 39 & 0.70 & 0.00 \\
\hline$\Delta$ Secondary Enrollment (gross) & 1.36 & 0.279 & 34 & 0.47 & 0.01 \\
\hline
\end{tabular}

\footnotetext{
${ }^{6}$ In Lake and Baum's (2001) study these variables were used in different forms. Instead of looking at the impact of democratization, they were analyzing the impact of the level of democracy. For this reason, they used similar variables but not as averages over the entire period, like I needed to do.
} 
The results, which are remarkably consistent across all five indicators, indicate that democratic improvements in Africa after 1990 are not significantly associated with improvements in social services and related outcomes. One can interpret this to imply that during this time frame, Africa's democratic progress has not coincided with changes in policy that would directly impact the quality of life in Africa. These results lead to another essential question: have regime type and social services ever been related in Africa? As mentioned earlier, several authors have pointed out that certain prominent African political characteristics, like ethnic voting and clientelism, might undermine electoral accountability. Thus democracy might never correlate with social service coverage and quality of life in Africa irrespective of the time period. In other words, if this is the case, we would not only see no effect of democratization on change in social service provisions, but we should also expect that social service levels in any given year and country are not related to democracy levels at that time.

To investigate this question, I explore in a second set of analyses the relationship between a country's levels of democracy and social services at two moments in time: 1990 and 2005. This approach allows me to explore whether democracy impacts social service levels and compare its effect across one period, before democratization, and another, after. Because I am interested in comparing democracy's impact on social services and outcomes across two time periods, I run two separate OLS cross-sectional regressions for each quality of life indicator, using the indicator's level, instead of change, for each year (1990 and 2005) as the dependent variable.

For the measurement of democracy, I again refer to the Freedom House indicators, but I recode the standard scores. Countries considered "not free" are rescored as a 0, while countries considered partly free and free are scored as a 1 and 2 respectively. The primary theoretical 
reasoning why democracy is supposed to positively influence public goods provisions is electoral.

Democracy indicators from Freedom House and Polity are subjective scores based on many

different criteria, and so it is not clear that two countries with scores of a one unit difference would

have markedly different levels in the potential to have electoral accountability. It is likely that

regimes coded as a 6 and 7 (most authoritarian) are similarly unthreatened by a public's negative

evaluation of their performance. By simplifying the more continuous democracy scale I introduce

categories between which differences in government behavioral expectations are likely to take place.

Other studies have also recoded democracy in a similar manner for the same reason. Scholars have

found it useful to use dichotomous (democracy/no democracy) or trichotomous

(democracy/autocracy/mixed regime) variables (Kaufman and Segura-Ubiergo 2001, Brown and

Hunter 1999, Ross 2006, Huber, Mustillo and Stephens 2004), or indices that measure specific

institutional characteristics of executive promotion and political inclusiveness when analyzing

democracy's proposed effect on public goods provisions. ${ }^{7}$

I use the same controls as in the previous regressions, albeit sometimes in a different form.

Instead of using averages over a time frame for GDP per capita, percent of population that lives in

an urban area, and population size, I simply use the amount/percentage for each year of the

regression to control for the specific context of that given time period (1990 or 2005 respectively).

The civil war dummy variable was recoded to reflect a 1 if the country had a conflict in the

preceding ten-year period, to control for any negative lingering effects conflict may have on social

service delivery (since 1980 for 1990 regressions, and 1995 for 2005 regressions).

\footnotetext{
${ }^{7}$ One might argue that the previous analyses (the effects of democratization on change in social services) should also be recoded, as small changes in democratization will not likely impact changes in social services. I did rerun these regressions with a different coding of Freedom House scores as well. Specifically, countries that had a change of only 1 point, were recoded to have zero change at all; countries that had a change of 1.5 to 3.5 points were recoded to have had a change of a 1 (adjusted for the direction of the change, i.e. negative changes of this magnitude were given a negative 1; and countries that had changes of anything above 3.5 were given a 2 on the recoded change in democracy scale. The results remained the same, however, democratization was still not found to be significantly related to change in social services. One might also argue that this should also be captured by the reported regressions as the dependent and independent variables are both change, thus it is sensitive to the differences in magnitude to change already.
} 
Table 2: The Relationship between Democracy Levels and Quality of Life Levels at 1990 and 2005

\begin{tabular}{|l|l|c|l|l|l|l|}
\hline & Year & Democracy Coefficient & P-value & $\mathrm{N}$ & $\mathrm{R}^{2}$ & F-test \\
\hline \multirow{3}{*}{ Infant Mortality Rate } & 1990 & -18.11 & 0.017 & 46 & 0.37 & 0.00 \\
\cline { 2 - 7 } & 2005 & -11.11 & 0.040 & 47 & 0.29 & 0.03 \\
\hline \multirow{3}{*}{ Life Expectancy } & 1990 & 4.20 & 0.014 & 46 & 0.40 & 0.00 \\
\cline { 2 - 7 } & 2005 & 1.96 & 0.193 & 47 & 0.21 & 0.14 \\
\hline \multirow{3}{*}{ \% Undernourished } & 1992 & -7.59 & 0.048 & 42 & 0.30 & 0.04 \\
\cline { 2 - 7 } & 2004 & -3.27 & 0.353 & 44 & 0.41 & 0.00 \\
\hline \multirow{2}{*}{ Primary Enrollment (net) } & 1991 & 13.16 & 0.018 & 41 & 0.33 & 0.03 \\
\cline { 2 - 7 } & 2005 & 4.71 & 0.206 & 43 & 0.31 & 0.03 \\
\cline { 2 - 7 } & 1990 & 9.03 & 0.014 & 44 & 0.33 & 0.02 \\
\cline { 2 - 7 } & 2005 & 8.89 & 0.030 & 44 & 0.39 & 0.00 \\
\hline
\end{tabular}

The results in table 2 are as interesting in their own right as they are in contrast to those of table 1, and offer important insight into the nature of the relationship between democratic rule and social service provision in Africa. The results show consistently that there was a relationship between democracy and social outcomes in 1990 but that it had largely evaporated by 2005 . Specifically, the relationship weakens for infant mortality and secondary enrollment and altogether loses significance for life expectancy, undernourishment and primary enrollment rates. Additionally, at first glance, a comparison of the slope coefficients shows that the estimated impact of democracy decreased from 1990 to 2005. In three out of the five analyses (life expectancy, undernourishment, and primary enrollment rates), democracy's effect is estimated to be at least 50\% less in 2005 than it was in 1990 . In the case of infant mortality it is around $40 \%$ less. ${ }^{8}$ However, in the case of secondary enrollment rates it remains about the same throughout the two periods. ${ }^{9}$

\footnotetext{
${ }^{8}$ A further analysis wherein I pooled the two years and tested an interaction between a dummy variable for the $1990 \mathrm{~s}$ observations and change in freedom house scores revealed that the estimated coefficients were not statistically different from each other across both years.

9 Full democracies might not have the same "gap" between themselves and non-democracies if the full democracies reached their potential in 1990 and had little room to move to 2005, and non-democracies converged. A descriptive look at the data shows some support for this. On average non-democracies do improve a lot over the 15 years in question, and some of the free countries in 1990 seemed to reach impressively high coverage rates for many of the public goods.
} 
These results reveal another important puzzle. On the one hand, they testify to Africa's normality, the banality (Bayart 1993) or universality of its politics as they help dismiss the idea that African political and societal features hinder a relationship between democratic governance and responsiveness through social services. On the other hand, however, they beg the question of why democracy's impact on the quality of life eroded after the wave of democratization. Put differently, the different findings across periods highlight the possibility that the wave of democratization in the 1990s transformed the relationship between regime type and social services in the region. Despite the fact that more of Africa's leaders now face the threat of being voted out of office, I find that these new democrats have failed to distinguish themselves in terms of providing their citizens a certain quality of life to the same extent that their predecessors did in Africa's older democracies. How can this disassociation be explained? What does it reveal about the substance of the third wave of democratization in Africa? What political differences can we find between Africa's newer and older democracies to account for the variation in their respective performance?

In this dissertation, I explore a hypothesis that might account in part for the observed discrepancy. My argument relies on the concept of "strategies of extraversion" developed by Bayart (1993; 2000). According to Bayart, regimes in Africa have used their dependence on, and access to, the international system to extract resources in order to remain in power at home. They have historically instrumentalized their international weakness to gain domestic political advantages. For example, governments have unique access to resources like foreign aid and rents from the international market wherein nationalized natural resources are sold. Governments are then able to

Yet to depict that Africa is converging on high equilibrium of public goods provisions is not accurate at all. On average for both periods and across most indicators the average coverage of public goods of free African countries is lower than that of the world average. It might be possible that they have converged towards a high equilibrium for their income group though. To control for a possible convergence, I re-ran all of the above 2005 analyses controlling for the 1990s levels of the indicators. If the countries were just converging, then democracy should come out significant with this added control. In none of the analyses was this found. 
translate their access to resources derived from the international system into domestic strategies, like repression and coercion, which help them secure their power domestically.

While regime change is certainly in large part a function of domestic economic, social and political developments, the paradigm of extraversion highlights the crucial role that changes in the international system might also play on the proclivity of extraverted regimes to succumb to democratization. In this light, the 1990s democracy wave that several regimes were impacted by, I argue, can be interpreted as a function of a changed international system. With the end of the Cold War, the United States and other European countries detracted from their program of supporting Cold War allies in the region and instead focused on promoting and pressuring for democratization in Africa, in exchange for foreign aid and other resources (Carothers 2006). Thus, in the post-Cold War world, many regimes that were particularly dependent on foreign support and domestically weak found that they had to concede democratic political reforms for the foreign support that they previously were heavily reliant on.

Thus, the democratic change that most regimes underwent during the early 1990s can be characterized as more exogenous than endogenous, meaning that the driving force behind the timing and substance of political liberalization came from foreign, rather than domestic forces. With their accountability tilted towards foreign patrons rather than domestic constituencies, extraverted democratizers are less likely to develop responsiveness to their citizens through social service delivery. In other words, post 1990 democratic changes lack accountable substance; the spread of elections and civil rights do not translate into more responsible governments in terms of policy performance. Leadership of these "exogenous" democracies remain primarily accountable to foreign actors which pressured the political change. However, donors lack the willingness and ability to generate a higher degree of domestic responsiveness from abroad. Additionally, while exogenously pressured democratic reforms usually include the institutionalization of formal 
democratic practices, like multiparty elections, they are also likely to result in giving the ruling party a near political monopoly, due to the lack of a strong domestic democratic watch dog, all of which decreases the electoral incentive to produce higher levels of services.

This dissertation chapter has highlighted several descriptive findings and summarized the academic literature on the role that regime type might play in determining social service provisions. Comparatively, African governments perform poorly when it comes to providing their citizens with social services, and thus the quality of life for many Africans has been compromised. When one unpacks the continent, some shining stars do emerge, as reflected in the great deal of variation in social services on the continent. In the literature, cross-national variation in social services provisions has been explained to be at least partly the product of variations in regime types: democracies generally provide higher levels of social services than non-democracies. Yet, when I examine this relationship in the African context, I find an empirical puzzle. Democratization has not been associated with increases in social service delivery. Additionally, a country's level of democracy is less associated with social service provisions after the wave of democratization then it was before.

In the next chapter I examine the trends and determinants of the 1990s democratization wave; a better understanding of the democratic wave gives insight into the central puzzle of this dissertation. Descriptively, I unpack the democratization wave and I document that while some countries experienced a dramatic shift towards more democracy, for the majority of countries liberalization was more modest or non-existent. Additionally, the "democratic wave" on the continent was largely experienced in just the first five years after the Cold War; subsequently, most regimes have consolidated at the level of democracy that they ended up at in the mid 1990s. These descriptive findings beg the following questions: what can explain the variations in the degree of political liberalization during the 1990s on the continent? And, why have many regimes consolidated 
at the level of democracy they ended up at in the mid 1990s? With respect to these questions, I find that variation in the degree of initial liberalization and subsequent consolidated regime type can be better explained by a country's vulnerability to new foreign pressures to adopt democratic reforms, which arose after the Cold War, than to domestic sources of pressure.

Chapter three expands upon the lessons from chapter two on the determinants of democracy trends on the continent into an argument that addresses the dissertation's central question, why was the 1990 s democratization not associated with a positive change in the quality of live on the continent? Specifically, I argue that it is the exogeneity of democratization on the continent that has disassociated political liberalization from changes in the quality of life. Further, I develop a measure of exogenous political change and illustrate that once exogenous political change is accounted for, democratic change in Africa is associated with positive changes in social service delivery. This finding directly addresses the puzzle presented in this chapter and supports my argument that the foreign nature of democracy on the continent has disassociated political liberalization with social service increases.

In chapter four I summarize the findings from in-country, qualitative fieldwork in Zambia, a country where foreign influence was important to the regime's decision to concede multipartyism. There I examined how citizens demand social services and how the government responds to such demands. This research allows an "on the ground" look of the mechanisms, which are supposed to bind citizen demand to political incentives in a foreign influenced, multiparty setting. There, I found that multipartyism ushered in institutional changes meant to decentralize and increase local government responsiveness post-transition, however their effectiveness at inducing a greater degree of responsiveness was undermined by democratic backsliding and a lack of political will to decentralize power from the center. The current political situation in Zambia, best characterized as an unresponsive and hybrid multiparty system, I argue, is partly a product of the extraordinary 
influence that foreign actors had on the impetus to democratize and Zambia's subsequent consolidation as a hybrid multiparty democracy.

In chapter five I turn to a slightly different question: how has foreign influenced democratization impacted public support and satisfaction with democracy? I use Afrobarometer's cross-national survey data to explore these issues and find that exogenously derived democratization has a small negative impact on people's attachment to democracy and satisfaction with the way democracy works in their country. Any negative impact that exogenously derived democratization may have on public support for democracy, I argue, may be detrimental to the future of democracy on the continent, as foreign pressure to main a certain level of democracy may wane in the future.

I conclude by pulling together the findings of each chapter to inform a discussion of the future of democracy on the continent and the agency of foreign actors in affecting the nature of democracy in Africa. Descriptively and analytically, this dissertation has a lot to offer, as it highlights an understudied topic of the influence of various types of transitions on long-term government responsiveness and, more to the point of policy implications, the unintended consequences of foreign influenced democracy movements. 


\section{Chapter Two: Determinants of Democratization and Regime Consolidation in Africa}

Any policy repercussions that one might expect to be born out of political change will be affected by the nature of the change itself. As evidenced in the previous chapter, democratic political change does not necessarily produce increases in coverage of social services or in the quality of life. Instead, I found that Africa's most recent wave of democratization correlated with a disassociation between regime type and social service delivery. Insight as to why this was the case, I argue, can be found in examining the determinants of the post-Cold War democratic changes. The nature of a country's democracy is a product of its own unique evolution. The factors that push for political liberalization will be reflected in how a country's democracy functions, including its likelihood of being responsive to its citizens' social service needs. Thus, the question of why Africa's newest democracies are not providing higher levels of social services?, necessitates exploring what factors led to this wave of democratic change.

Aside from gaining perspective on the question of why such widespread political change did not impact social services, the post-Cold War democratization wave in Africa provokes several other important questions. Between 1990 and 199539 countries in Africa held multiparty elections, 32 of them their first ones in over a decade. In contrast to previous democratic experiments on the continent, the new African democracies have exhibited surprising staying power. By 2000, thirty-five countries had held more than one cycle of competitive elections (van de Walle 2002). Since most African countries lack much of what is commonly thought to be democracy's prerequisites, like a powerful middle class (Joseph 1997: 363), the question arises: what brought on this wave of political change? Moreover, why have democratic trajectories on the continent generally followed a similar trend over time as this chapter will show? In the early 1990s there was intense, but divergent regime change which has been followed by a largely static period with most regimes consolidating at 
whatever level of democracy they had reached by 1995. Thus an answer for what explains variations in democratization across Africa must account for the fact that African democratization has occurred in these two phases.

In this chapter, I offer a theory of African democratization that is able to explain variation in the extent to which it occurred during the first half of the 1990s and the relative subsequent stability in regime type. I focus on the dependence that African elites have on the international system and rely on the idea of extraversion, i.e. their propensity to convert their international dependence into domestic benefits. Variation in democratization is partially accounted for by the fact that regimes vary in the type of international resources they are dependent on, foreign aid being only one of them. I develop the concept of extraversion portfolios to distinguish the different assets that states can rely on in their extraversion strategies. In addition, I discuss the fact that foreign aid donors have mixed motives, value democracy differently at different levels of democracy, and face difficulties in monitoring setbacks. When these donor idiosyncrasies are considered, I show that different degrees of vulnerability of extraversion portfolios to donor demands account for variations in both initial regime changes and subsequent consolidations across Africa. This discussion allows me to highlight the idiosyncratic nature of Africa's most recent democracies and offers a causal step in my analysis of the weakening of linkages between democracy and social service in Africa over time.

I begin with a discussion of the empirical patterns. I then review prominent theories of democratization and their applicability to the African context. I discuss the notion of extraversion portfolio, of its relationship to aid, and of certain peculiarities of donor behavior with respect to democratization, and develop an argument as to how variations in these variables and their interactions correspond to regime variations. I then compare a model of transition based on variables derived from this theory of extraversion and democratization to one based on more 
commonly used variables, and do the same for a model of consolidation. In each, variables which capture vulnerability in extraversion portfolios have greater explanatory power than prevailing models. In the next chapter I discuss how these findings shed light onto the disassociation between democratization and social services in Africa.

\section{Transitions and Consolidations}

One cannot make sense of democratization in Africa without first picturing its changing nature over time. The period immediately following the end of the Cold War was characterized by a rapid positive average change in the level of democracy across the continent. Since 1995, however, African democratic performance has largely stagnated. While this overall "end of transition" pattern (Carothers 2002) is well known, a more detailed look reveals that the initial transition itself differed broadly across African countries, from radical democratization to increased authoritarianism, and that the subsequent consolidation has largely taken place at all levels of democracy. In other words, the current regime distribution across the continent—with nine "free," 23 "partly free" and 16 "not free" countries — has been steady for almost two decades. About $90 \%$ of the countries that were democratic in 1995 were still democratic in 2009 , and about $75 \%$ of the partly free ones were still partly free. Altogether, some 64\% of total democratic change across the continent between 1989 and 2009 can be imputed to changes between 1989 and $1995 .^{10}$

While it is not unusual for regime characteristics to correlate over time within regions, such consolidation is surprising in Africa, not only because its few democracies endure despite missing several of the alleged prerequisites of democracy, but also because its "hybrid" regimes seem to be in a state of equilibrium, neither transitioning towards more democracy nor reverting to the full-fledged

\footnotetext{
${ }^{10}$ Results based on robust bivariate regression of overall change in civil liberties on initial change between 1989 and 1995. We use Freedom House's civil liberties index as our indicator of democracy throughout this paper. Although it does not fully capture all dimensions of democracy, it helps us better compare our findings with that of other studies which also use it Our results are not substantially different when using Freedom House's political rights index instead.
} 
authoritarianism they displayed before the 1990s. Typical of these regimes is that they hold regular elections and provide their citizens with some liberties, while nevertheless using autocratic and clientelistic means to maintain their effective monopoly over power (Joseph 1998; Diamond 2002; van de Walle 2003; Tripp 2010). Thus, the large proportion of partly free or hybrid countries in Africa (at $48 \%$ the largest of any region in the world) has become a steady feature of its regime distribution rather than a stage in the continent's course towards or away from democracy.

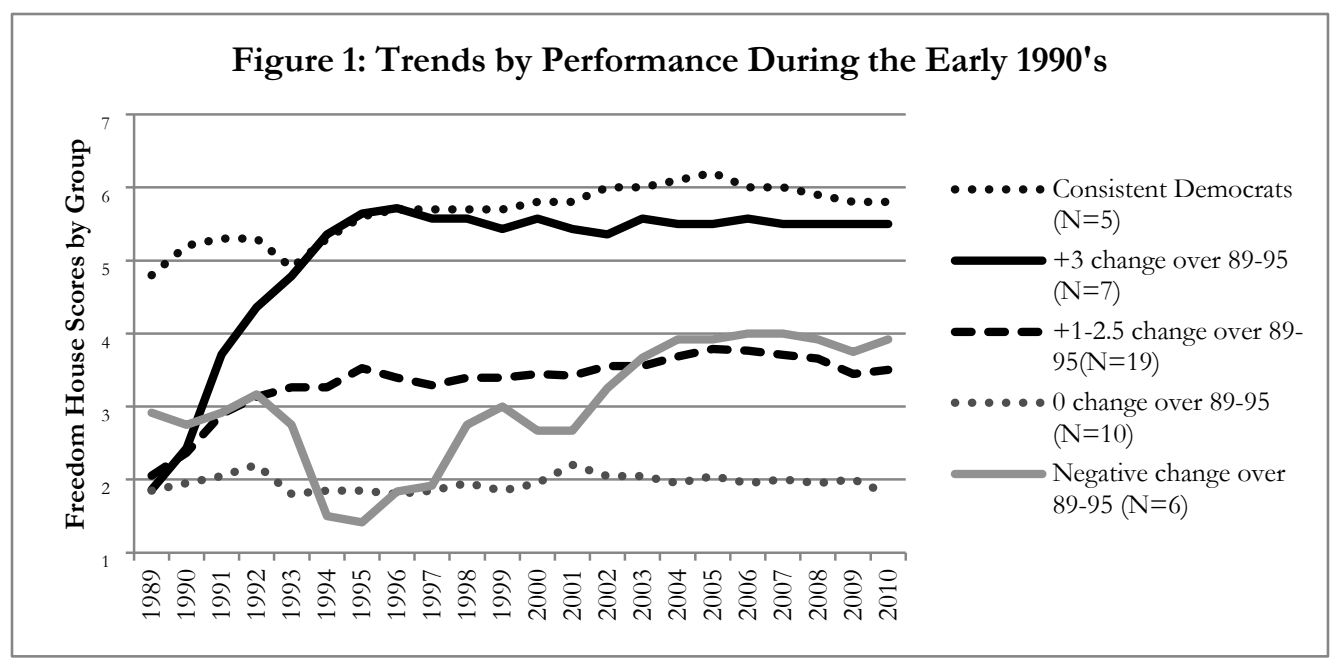

Figure 1 illustrates this empirical pattern by highlighting the trajectories of five groups of countries, which differ in their initial trajectories and subsequently tend to behave similarly.

Specifically, in the figure, countries are categorized by how much their freedom house score changed from 1989 to 1995. Put differently, they are grouped by the degree of democratization the country experienced during the early 1990s. As the figure shows, by and large, each category stays at the level of democracy they ended up at in 1995. Breaking down the pattern by group highlights the degree to which country experiences are similar within each group. 


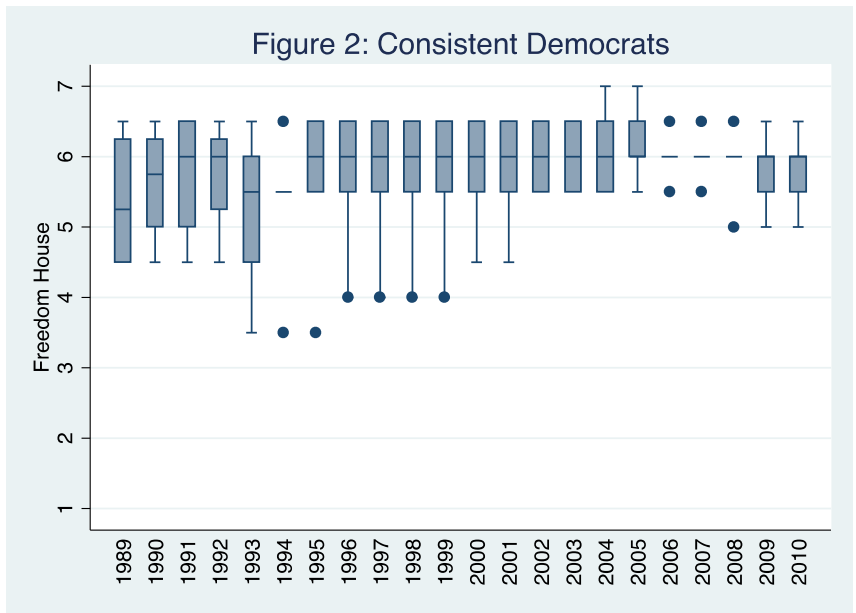

The "consistent democrats" of Figure 2 are the countries that had multi-party political systems before 1989—-Botswana, Mauritius and Senegal—as well as Namibia (which becomes independent as a democratic country in 1991) and South Africa (for which I do not include data before the end of apartheid). The essential feature of these countries is their constant level of democracy: they are solidly democratic throughout the transition and after. As Figure 2 suggests, they tend to move together in a narrow band around scores of 5-6, although Senegal was responsible for a temporary dip in the 1990s.

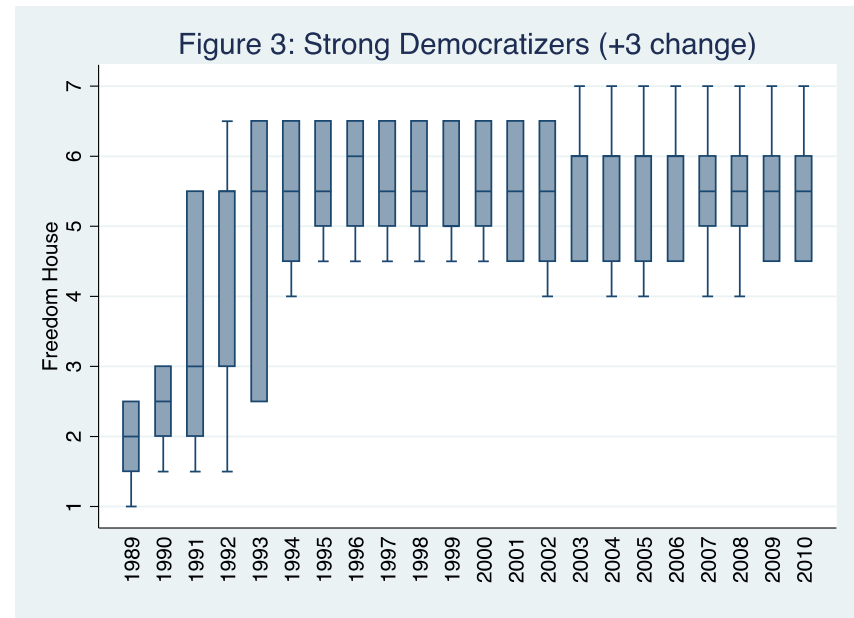


The second group, "strong democratizers," consists of countries with an increase of at least 3 points on the Freedom House index between 1989 and 1995. Such an increase guarantees a qualitative jump from one category to another (from "Not Free" to "Partly Free" or from "Partly Free" to "Free"). These countries are Benin, Cape Verde, Malawi, Mali, Mozambique, Sao Tome and Principe and the Seychelles. With the exception of Malawi, which subsequently fell back by one point, these countries all stayed where they were as of 1995 or continued to improve.

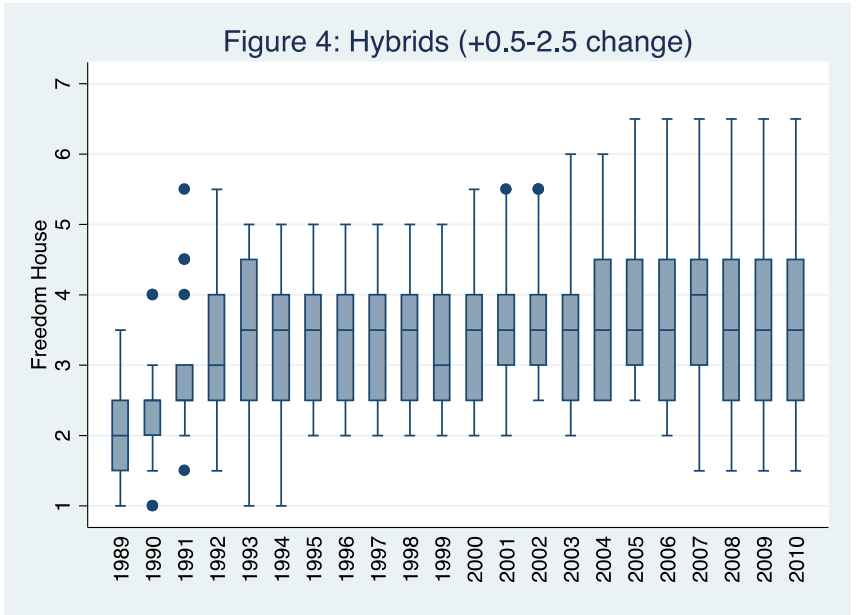

The third group consists of countries that showed a small (.5 to 2.5 points) initial improvement. Their transition also tended to be shorter and was largely over by 1992 . This is the largest group, with 19 observations. It comprises Angola, Burkina Faso, the Central African Republic, Chad, the Comoros, Congo-Brazzaville, Eritrea, Ethiopia, Gabon, Ghana, Guinea, Guinea-Bissau, Lesotho, Madagascar, Niger, Tanzania, Togo, Uganda and Zambia. Ghana alone becomes democratic and, together with Tanzania, is one of only two countries among this group to show improvement after the initial transition to eventually climb by 3 points. All other countries have stayed close to their 1992 level. 


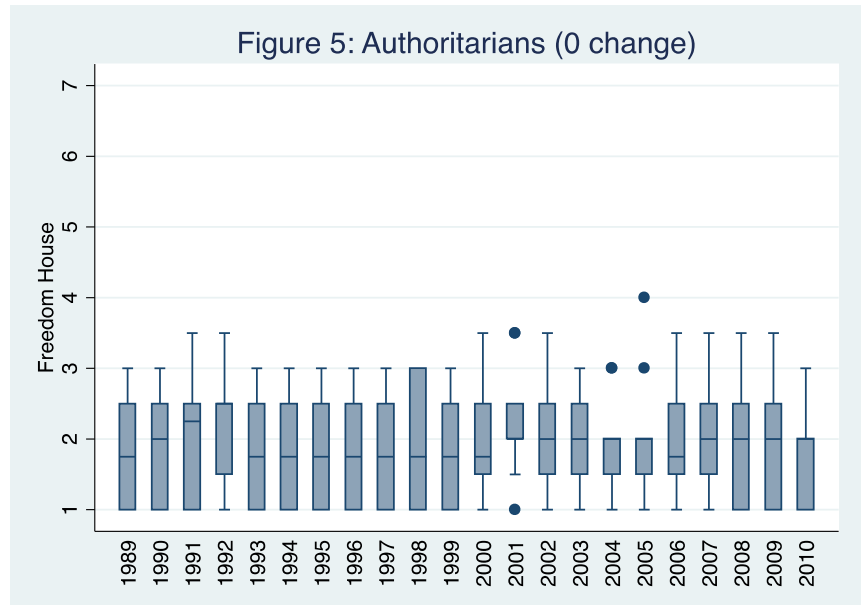

A similar pattern is visible among the category of countries that displays no net change in the initial period (a few of them display a small positive change between 1989 and 1992 followed by a reversal before 1995). By and large, nothing happens to them subsequently either, although their average creeps up from close to 2 to close to 3. These countries are Burundi, Cameroon, CongoKinshasa, Côte d'Ivoire, Djibouti, Equatorial Guinea, Somalia, Sudan, Swaziland and Zimbabwe.

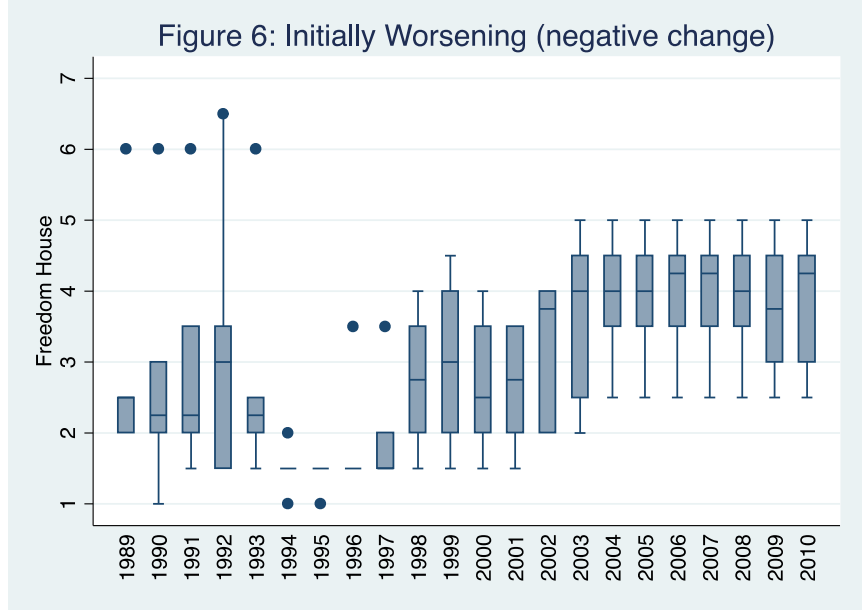

The last group consists of countries that had an initial negative change. They moved in the opposite direction from the rest of the continent during the 1989-95 period. On average, they 
ended in 1995 about a point and a half below their 1989 level. Unlike other groups that stayed flat, they subsequently recouped their losses and eventually converged with countries that had shown an original small gain. Although they do display change after 1995, it should be stressed that they stabilized around their original level of democracy pre-transition. Several of these countries actually experienced civil conflict or other forms of state failure in the initial transition, which was responsible for their drop. Post-conflict multilateral interventions and donor-sponsored elections were largely responsible for their subsequent catch-up. These countries are the Gambia, Kenya, Liberia, Nigeria, Rwanda, and Sierra Leone. Nigeria experienced a dictatorial drift after 1993, followed by a late democratization after 1998, which apparently ran out of steam within about five years.

With very few exceptions, each category displays a pattern of consolidation at its own level of democracy following 1995. As mentioned earlier, initial change largely predicts overall change. Of course, there remains some variation within each group. Ghana and Tanzania's later transitions particularly stand out among the hybrid category. In general, however, this within-group variation is much smaller than between groups. In other words, the aggregation of countries by initial transition explains more variation than there is altogether within each group. This is shown in Table 1 by using an analysis of variance, which measures and tests the significance of variations among groups as a ratio of average variations within the groups. If one compares the eventual levels in freedom house scores as of 2009, the between-group variation is more than 15 times bigger than the withingroup variation. If one compares, instead, overall freedom house scores between 1989 and 2009, the ratio is about 9 . Both ratios are very statistically significant. 
Table 1: Analysis of variance of 2009 freedom house scores by initial change (1989-95)

\begin{tabular}{c|ccccc} 
Group & $\mathrm{N}$ & Mean & Std. Dev. & Min & Max \\
\hline Consistent Democrats & 5 & 5.8 & 0.57 & 5 & 6.5 \\
Strong Democratizers (3+ Change) & 7 & 5.5 & 0.91 & 4.5 & 7 \\
Hybrids (1-2 Change) & 19 & 3.45 & 1.23 & 1.5 & 6.5 \\
Authoritarians (0 Change) & 10 & 2 & 0.85 & 1 & 3.5 \\
Initially Worsening Regimes (< 0 Change) & 7 & 3.35 & 1.34 & 1 & 5 \\
ANOVA F Test for level of freedom house score in 2009: & & & & \\
F (4, 43) = 15.91*** (Prob > F = 0.0000) \\
ANOVA F Test for change in freedom house score, 1989-2009 (sample means not shown): \\
F (4, 42) $=8.98^{* * *}$ (Prob $>$ F $\left.=0.0000\right)$
\end{tabular}

\section{Democratization Theory and Africa}

What can explain the variation with which regimes adopted democratic institutions? How can we understand the consolidation of regime type after 1995? While there have been several studies on democratization and consolidation cross-nationally (Ingelhart 1997; Przeworski et al 2000; Ingelhart and Welzel 2005; Acemoglu and Robinson 2005, to name but a few recent ones), few have generated theoretical correlates which can account for regime variation within Africa, as illustrated by the main quantitative studies of democracy on the continent (Bratton and van de Walle 1997; Dunning 2004; Lindberg 2006). Although this might be due to the fact that some of the variables associated with democratization remain difficult to measure on the continent, many of these correlates might also be derived from theories that are not applicable to the general African context.

Of all the correlates found to be associated with democratization and the consolidation of democracy, those derived from modernization theory are probably most commonly accepted as conventional wisdom in cross-national analyses. ${ }^{11}$ To roughly summarize, modernization describes a process of social and economic changes that are borne out of industrialization. These changes include increased occupational specialization, urbanization, rising educational levels and rapid

\footnotetext{
${ }^{11}$ I do not intend to argue that modernization's theoretical implications have not been debated. I refer to the variables associated with the theory as conventional wisdom because they are regularly controlled for in most cross-national quantitative analyses on variations in democracy for reasons along the same line that modernization would propose.
} 
economic growth. Combined, these transformations are likely to produce a relatively more educated and economically important middle class that values a more democratic culture. This class will hold new political and economic leverage over the political system. Thus, according to modernization, democratization is likely to occur when an empowered middle class with sufficient economic and political leverage is present to demand and succeed in gaining such changes from a regime.

Democracies, therefore, are likely to have high levels of income, education and will possess an economically important capital class (Lipset 1959; 1960; Inglehart and Welzel 2009; Inglehart and Baker 2000; Inglehart 1997).

One might expect that a democracy created at the behest of a politically powerful and relatively educated middle class would be most likely to produce leadership who are responsive to the basic social service demands of its citizenry. Assumingly, given their level of education, this segment of the population would be better informed about the need for services. Additionally, the political leverage wielded by this segment could be used to pressure for increased coverage in social services. Africa's democracies, however, differ insignificantly from their authoritarian counterparts on many of the correlates that modernization theorists would propose democracy to have (income, education and the presence of an economically important capital class).

Although some of Africa's richest countries, like Botswana, Mauritius and South Africa, are democracies, their democratic trajectories hardly follow the modernization narrative as the former two were already democratic before getting rich, and the latter had one of the continent's most repressive regimes while being possibly its richest country until 1994. Additionally, some of Africa's most democratic countries (Benin, Cape Verde, or Mali) are also among the poorest in the world. To some extent, the lack of correlation between income and democracy in Africa derives from the nature of the continent's economies. While the effects of income on democracy are supposed to be mediated by the development of industrialization and the rise of a middle or entrepreneurial class, 
African national incomes and episodes of growth are more often the result of extractive economic activities and variations in commodity prices. ${ }^{12}$ Unlike manufacturing, extractive industries are typically capital-intensive expatriate-dominated enclaves. Such wealth concentration is less likely to grow a potentially politically powerful middle class and more likely to embolden authoritarian regimes (Ross 2001).

While modernization's theoretical implications suggest that higher incomes will correlate with democratization and sustained democracy, arguably, its key causal mechanism lies in the idea that economic development will produce a bourgeois class which will have economic leverage over an authoritarian regime to demand democratic concessions. A more direct measure of the strength or size of a capital class might be the share of GDP accounted for by manufacturing, because as Acemoglu and Robinson (2005) have suggested, elites who have invested in manufacturing capital are loath to see it destroyed and thus more likely to compromise about democracy. Yet, in Africa, the correlation between the share of GDP accounted for by manufacturing between 1985 and 2008 and the average freedom house civil liberties score over the same period is a statistically insignificant $\mathrm{r}=0.08 .{ }^{13}$ To a large extent, this lack of relation is due to the very limited range of manufacturing (and of other economic indicators) in Africa. The puzzle with democratic theory in Africa is to explain variations in democracy while there are few variations in its usual correlates.

This problem also applies to education which, according to modernization, is expected to lead to the acquisition of tolerant and democratic values (Lerner 1958; Inkeles and Smith 1974). The correlation between the log of literacy and civil liberties over the same period as above is not either statistically significant $(\mathrm{r}=0.09)$, in part due to the limited range of variation in literacy in Africa.

\footnotetext{
${ }^{12}$ While Przeworski et al (2000) have challenged modernization by showing that democratic transitions can happen at any level of income, in line with modernization's predictions for democratic consolidation, they find that consolidation does not take place in countries with incomes below $\$ 6,000$ per capita (PPP). This income level, however, is well above the average for African democracies

${ }^{13}$ Value added in manufacturing as \% of GDP from World Development Indicators (accessed 29 January 2010).
} 
Hence democratic Mali has a literacy rate of 26 percent, while that of neighboring authoritarian Niger is 29 percent. ${ }^{14}$ Thus, in large part, Africa's democracies lack the correlates that a modernization theorist would usually associate with political liberalization. That Africa's newest democracies evolved without these elements might give some insight to why they have failed to return governments responsive to the social service demands of its citizenry.

Resource curse arguments fair slightly better in predicting regime variation on the continent. Under this theory, resources are thought to limit the likelihood of democratization because governments can use their rents to finance extensive networks of patronage and/or provide social services to garner support and/or fund internal security efforts used for repression (Ross 2001). Success stories of democratic consolidation on the continent seem indeed to be more likely among resource poor countries. Benin, Mali, Sao Tome and Principe and Seychelles, all countries that democratized during the early 1990s and have consolidated as democracies, are relatively resource poor (Sao Tome's first oil production licenses were sold in 2004 and production has yet to begin). Conversely, resource rich countries like Angola, the Republic of Congo, Gabon or Sudan have remained steadfastly authoritarian over the years. Studies have confirmed the presence of a "resource curse" in Africa with more mineral-rich countries less likely to democratize (Jensen and Wantchekon 2004; Omgba 2009). ${ }^{15}$ Additionally, the resource curse theory may help to explain the lack of differentiation in social service coverage between democracies and non-democracies on the continent. In this light, the extension of broad based social services by a resource rich government would likely be seen as a payoff of the population to dispel democratic demands. Theoretically, we

\footnotetext{
${ }^{14}$ Data from the World Development Indicators (accessed March 12, 2010). Both are for the most recent date available, which was 2006 for Mali and 2005 for Niger.

${ }^{15}$ While not looking at the impact of natural resources on regime type, Omgba (2009) does find that the presence of oil reserves made authoritarian leaders on the continent more resilient, as evidenced by its positive effect on their tenure in power.
} 
might expect that some resource-rich non-democracies would have similar levels (or higher levels) of service coverage to some new democracies.

Resource wealth still falls short, however, of explaining the entire regime distribution picture in Africa. For one, Botswana-one of Africa's democratic stars—is a deeply mineral economy. In addition, the absence of mineral resources is in no way systematically associated with democracy, as witnessed by the performance of countries such as Côte d'Ivoire, Kenya or Zimbabwe. Moreover, resource-curse types of explanation do not account for hybrid consolidation, which occurs as much among resource-rich as resource-poor countries. Thus, the resource curse theory makes a more ambivalent contribution to our understanding of regime distribution and social service coverage in Africa.

The social configuration of countries is one of the non-economic variables most often associated with democratic performance. Particularly, more culturally homogeneous countries are expected to have an easier time democratizing and staying democratic than their more heterogeneous counterparts. The more homogeneous, the more similar the population's policy preferences and the lesser acute the demands for patronage and redistribution (Easterly and Levine 1997). However, as Daniel Posner's work has shown (2004; 2007), the salience of ethnicity in Africa is more likely to be a function of the rules of the political system than the other way around. In Zambia, the switch from single- to multi-party politics reduced the effective degree of ethnic heterogeneity in the country. It is thus often unhelpful to think of ethnic distribution as hard-wired and causally related to political outcomes. Moreover, Habyarimana and others' recent work suggests that ethnicity is more likely to function as a facilitator of collective action within groups rather than as a factor of polarization across them (2007). These findings, as well as the absence of any ethnic effects among existing quantitative studies of democracy in Africa, suggest that looking for ethnic causes of democratic performance is a largely blind alley. 
There is, however, a possibility that African countries vary in terms of their civic culture in ways that correlate with their democratic performance (Almond and Verba 1963). This argument suggests that some societies have a greater disposition towards democracy than others because they share values that are favorable to compromise, communication, consensus and diversity. Putnam (1992) offered a more recent incarnation of this theory in which levels of social capital—social trust, horizontal social relations, associate life_correlate with democracy. Yet, civic-culture types of argument are difficult to formalize or verify. The little work that has been done on social capital in Africa has actually found that there was less of it in democratic Botswana than in more authoritarian Uganda (Widner and Mundt 1998). And arguments that have equated trust with ethnic homogeneity have not fared better in Africa (Knack and Keefer 1997). In general, the lack of culture data aggregated at country levels across the continent precludes further empirical investigations.

Yet, one can identify plausible variations within Africa of a factor that might be associated with a broad interpretation of civic culture. Although political cultures have significant indigenous elements, it is also true that African countries tend to maintain certain characteristics of the countries that colonized them. For example, former French colonies tend to have more centralized authority than their former British counterparts. This could partly be a function of whether or not colonial powers resorted to indirect rule. In a study of the effects of different colonial legacies on the rule of law in Africa, Sandra Joireman (2004) found that common law countries fared somewhat better. I find no effect, however, of differentiating countries by their colonial origins. Former French colonies as a group do not have visibly different scores from the rest of the continent on the Freedom House index. British colonies do slightly better but not significantly so. Former Portuguese colonies do significantly better and former Belgian ones significantly worse, but neither had very distinctive colonial systems and their limited number gives excessive leverage to a few observations. 
In summary, the variables conventionally associated with democratic theory have little explanatory power in Africa. Additionally, they shed little light on why democratization did not correlate with increases in social service coverage. Recently, however, Staffan Lindberg (2006; 2009) has offered evidence that associates democratic performance in Africa to the organization of elections. The very practice of elections helps to spread democratic values in society and contribute to improvements in civil liberties, Lindberg proposes (2006; 2009). This argument finds antecedents among theories that democratic change is more likely to occur in nations where past regimes held regular elections, even more so if they allowed some degree of competition among parties, however superficial such allowances were. Bratton and van de Walle (1997:141) argued that regimes that held regular elections, even if it was a single party state, institutionalized a tradition of mass participation, wherein elites and the masses became socialized to accept participatory political roles. They found that such a history was positively associated with the presence of political protests which preceded many of the democratic transitions in Africa during the early 1990s. Bates (2008:163) finds that "the longer a country has been subject to a no- or single party system, the less likely it is to change to a multiparty system," a trend he terms "historisis.",16

While these theories were largely targeted at explaining the proclivity of a country to undergo a democratic transition, Lindberg's work has extended this logic to inform our expectations about democratic consolidation and current variations in democratic levels across the continent. According to him, variations in democracy in Africa can be traced to a self-reinforcing democratic power of holding consecutive multi-party elections. The practice of elections, he argues, promotes the creation of a virtuous lock-in mechanism through the spread of democratic values. Elections democratize a polity from the ground up, through several byproducts like the education of voters, training of domestic election officials, civil society organizations becoming more active, and added

\footnotetext{
${ }^{16}$ For a similar argument applied to Latin America, see Mainwaring and Perez-Linan (2008).
} 
media criticism, all of which contribute to a general increase in the likelihood that citizens will demand more civil liberties (2006:122-123).

While Lindberg does not directly address what effect electoral democratization might have on social services coverage, his theory might help explain why newer democracies perform worse than older democracies in this respect. Imaginably, the democratic byproducts that evolve and mature over several election cycles, like a more critical media, active civil society organizations, and more educated voters, could invigorate calls for responsiveness through social services. By this reasoning, newer democracies may just not have had enough time and opportunity to develop these grass roots institutions which are important to holding elected leaders accountable.

However, Lindberg's theory also suffers from its applicability to capture Africa's current regime distribution, which, as mentioned earlier, contains a large proportion of regimes which have continued to hold elections but have consolidated at a hybrid level. If the practice of elections inevitably leads to further political liberalization, then consolidation, for countries that regularly hold elections, at any level outside of fully democratic is hard to explain. Hybrid countries should be on their way to democracy rather than in equilibrium. Possibly, hybrid countries undergo recurrent cycles of elections and breakdown, but the narrow standard deviation of their freedom house scores index does not support that view.

Additionally, alternative measurements do not fully support his own findings and open the door for a more ambiguous interpretation of the effects of elections. Lindberg's (2006) measure of elections counts either the total number of presidential or the total number of legislative elections a country has had since its last "breakdown" (coup or civil war), whichever is most. ${ }^{17}$ It is, however, somewhat unclear why legislative elections in a presidential system (and vice-versa) or in a country with more presidential elections (and vice versa) would not have democratizing effects. Second,

\footnotetext{
${ }^{17}$ I inferred his method from information in the book and email exchanges with him.
} 
while there certainly can be valid reasons to reset the elections count after a breakdown, one wonders whether this might introduce some sort of bias in the data, in the sense that it makes the measure of elections somewhat endogenous to democratic developments. In other words, starting the count at 0 after a breakdown makes the number of elections a function of whether democracy encountered a setback. Whenever it does, it is deemed that elections never took place, and thus their effects on the current level of democracy is discounted to 0 . But why would the democratizing effects of past elections, particularly their progressive transformation of civil society, be lost if a handful of soldiers decide to overthrow the president?

In the statistical models present later, I retest Lindberg's findings with an alternative count of the number of elections, which does not reset the election count after each break down, as well as many of the other variables mentioned to be commonly associated with democratization. I compare these models with another, derived from a theory of African democratization that focuses less on the domestic sources of regime change and more on the important impacts that external factors have had on politics in the continent. This theory is discussed next.

\section{Theoretical Argument}

In this section, I offer a theory of African democratization that is able to account for the different initial transitions and the subsequent multiple levels of consolidation after 1990. Since I am ultimately interested in understanding why new democracies have failed to distinguish themselves from their authoritarian counterparts with respect to increasing social service coverage, I pay most attention here to the groups of countries that experienced some level of democratization, namely the "strong democratizers" and "hybrid regimes" of Table 1. The "consistent democrats" do not present a similar puzzle; there, democracy has been associated with social service delivery 
levels. Therefore, their path to democracy presents less of a puzzle, for my purposes. Additionally they did not engage in any substantive democratic change during the 1990s.

\section{Extraversion Portfolios}

One challenge to understanding the distribution of regime type in Africa lies in reconciling the similarity of politics across the continent with the extent of regime variation. Most African countries share features of neo-patrimonialism and personal rule, that is, the instrumentalization of state power and its resources for private and political purposes (Jackson and Rosberg 1984; Bratton and van de Walle 1997; Chabal and Daloz 1999; Pitcher et al. 2009). Most of them also engage in foreign relations based on seeking the patronage of rich countries, offering diplomatic allegiance and strategic benefits in exchange for resources, political support and non-interference in domestic affairs (Jackson 1990; Clapham 1996). More specifically, as Jean-François Bayart (1993; 2000) has identified and articulated, most African governments have historically gained, consolidated or maintained their power and resources by following policies of "extraversion." According to this hypothesis, African ruling elites employ their dependent relationship with the external world to appropriate resources and authority in order to establish or reinforce their power over domestic competitors. In the course of history, such strategies of extraversion have included the domestic instrumentalization by some elites of slavery, colonization, development aid, commodity exports, structural adjustment programs, and more. In Frederick Cooper's (2002:157) words, African governements are "gatekeepers," sitting "astride an interface between a territory and the rest of the world, collecting and distributing resources that [derive] from the gate itself." Thus, through the extraversion paradigm, African elites consolidate their power at home by relying and extracting resources from dependent relationships with actors external to the continent.

I argue that variation in regime type across the continent does not reflect meaningful differences in the degree to which regimes are neopatrimonial or rely on strategies of extraversion. 
Instead, I suggest that differences in regime type are in part a function of differences in the extraversion portfolios each regime has access too. A country's extraversion portfolio is made up of the specific linkages with the international system that a regime can exploit to extract abroad the resources it needs for domestic domination. Regimes vary, importantly, in terms of the make-up and diversification of their extraversion portfolios. Both the composition of one's extraversion portfolio and the extent to which the portfolio is diversified translates into different degrees of independence a regime will have from interference of the outside powers that it is reliant upon.

As governments rely on externally drawn resources to secure their own power at home, they potentially risk opening themselves to external influence on domestic governance. Certain extraversion linkages give foreign powers leverage to influence how the government operates at home, while others can act as a buffer against foreign pressure. For example, the rulers of a country like Benin have few avenues for appropriating international resources for their benefit. Like most African regimes, they can capitalize on their country's underdevelopment to invite aid flows. However, the Beninese regime has little else to offer in terms of attracting additional revenue or foreign support. Thus, the makeup and undiversified nature of Benin's extraversion portfolio leaves the regime's control of domestic power largely at the mercy of its donors.

In contrast, the Chadian government, for example, does not only instrumentalize its underdevelopment for attracting foreign aid, but also maintains close diplomatic ties with its former colonizer, France, for whose armed forces it provides a permanent base on its territory. It additionally holds geo-strategic importance in the context of the Darfur conflict in Sudan, a linkage which became particularly important when the country started to host UN troops. In each of these cases, international actors are at the mercy of the Chadian government's cooperation; arrangements like these afford the Chadian government bargaining chips if domestic political demands are asked of them by the international community. Finally, Chad is an oil exporter. Consistent with the 
resource curse argument, the extraversion paradigm would argue that a regime will potentially use the sale of a natural resource on the international market to extract necessary rents to fund its own efforts to remain in power. In Chad's case, at different times and in different circumstances, it can rely on one or the other (or several) of these extraversion assets. The specific balance of its portfolio gives the Chadian government considerable flexibility and relative autonomy from the specific political demands of donors, such as democratization.

\section{Vulnerable Extraversion Portfolios and Initial Democratization}

The diversification of a country's extraversion portfolios became particularly important at the end of the Cold War, when several countries lost their Soviet patron, and the United States and some European countries departed from their support of allies in the region and began making demands for democratization (Carothers 2006). Depending on the relative importance of Cold War geo-strategic factors in their extraversion portfolios, regimes became more or less vulnerable to these demands. Hence, African countries experienced the shock of 1989 differentially. Those with little to exchange for material and political resources became increasingly vulnerable to donor demands to democratize. They tended to be the countries closest to fiscal bankruptcy and debt default, most associated with the Soviet Union, and least endowed with natural resources.

Donors pulled at various linkages to prompt steps towards democratization, including "sticks" like aid withdrawal, refusing military support (to regimes that received it in the past) and sanctions, and "carrots" like promising to forgive debts, increase foreign aid flows, directly pay civil servants and pay for the elections themselves. The "carrots" transformed democratization from simply a step towards regime change to another linkage by which a regime could attract foreign support through. However, because democratization as a strategy of extraversion has the potential to threaten rather than to reinforce the power of incumbent elites, it takes particularly dire 
circumstances for incumbents to embark on such a high-risk strategy. Democratization was thus adopted mainly by regimes whose undiversified portfolios were particularly vulnerable because they had grown dependent on international aid and patronage over other sources of domestic authority and wealth (Levitsky and Way 2005).

Allegiance to a disappearing or changing patron might well have been the most important of these factors. The dissolution of the Soviet Union and other Eastern European communist regimes dealt a severe blow to the single-party African regimes which were Soviet clients and relied on similar ideologies for their domestic domination. The financial resources from the West also acquired greater importance and came with new, explicitly democratic conditions. For the 13 African Soviet clients identified by Thad Dunning (2004), I found that the average time from the fall of the Berlin wall in November 1989 to the adoption of multi-party politics was 14 months. For other African countries, it was 33 months (with some like Eritrea still counting), a difference statistically significant at the $5 \%$ level. $^{18}$

The number of former Soviet clients is indeed particularly high among the strongest democratizers. The Beninese regime had adopted Marxism-Leninism in the 1970s. It abandoned it in December 1989, the same month that France agreed to pay some of its civil service arrears in exchange for political reforms. ${ }^{19}$ Although most of its aid came from Western donors, Cape Verde too had been a client of the Soviet Union, from which it received technical assistance. Mali also had extensive and long-standing ties to the communist bloc. The Mozambican government, engaged in civil war since 1975, was dependent on the Soviet Union for military equipment and oil. It too dropped Marxism-Leninism in 1989 and announced the adoption of a multi-party system in July 1990. In Sao Tome and Principe, Manuel Pinto da Costa had allied his regime to Angola and the

\footnotetext{
${ }^{18}$ Based on a two-sample t-test with unequal variances.

${ }^{19}$ All case materials in this section are derived from Africa Contemporary Record, volumes XXII to XXV, unless otherwise indicated.
} 
Eastern Bloc, although a rapprochement with the west had begun in 1987. The Seychelles'

President France Albert René had public affinities for North Korea, where he went on four official visits, and was a protégé of the Soviets.

The post-1989 shift affected countries on both sides of the Cold War. Malawi, for example, was a staunch anti-communist western client whose regime had been sympathetic to white rule in Rhodesia and South Africa. Yet, President Kamazu Banda’s stock with the west considerably diminished with the end of the Cold War and the breakdown of the apartheid regime in 1991, and donors turned on him, suspending all non-humanitarian aid in 1992 for human rights abuses. That same year, Banda agreed to a referendum on a multi-party system, which he lost, as he did the May 1994 elections.

In contrast to being a Soviet client, French patronage did not require costly adjustments. For sure, especially after the La Baule Franco-African summit of June 1990, France demanded some political changes of its African clients, but France itself did not disappear and its African policy continued to be based on considerations other than just democracy promotion. Being also a client of France, which subsidized its day-to-day operations including most of its civil-service payroll, the Malian government was initially able to reject demands for multi-party politics. Yet, when the French government formally declared its expectations of democracy among aid recipients, the government was further weakened. Lacking the tools of accommodation, Moussa Traoré responded with violence. About 100 demonstrators were killed in two days before the army took over in March 1991. Although the new head of state, Amadou Toumani Touré (ATT) initially hoped to stay in power, he was warned by donors and he relented after a week. Other French clients, particularly those well-endowed in natural resources like Cameroon or Gabon, or those with a more strategic location like Chad or Dibouti, faced significantly less pressure from Paris to democratize or were better able to resist it. 
Vulnerability to the democratic demands of Western donors was thus not uniformly distributed across African countries, with the consequence that the regime trajectories they experienced immediately after the Cold War differed substantially. Others have pointed this logic out, at least as a partial explanation, before (Dunning 2004, Bratton and van de Walle 1997; Joseph 1997, 1998). In the next two sections, I look at consolidation and focus on the two most paradoxical categories of countries: those that democratized between 1989 and 1995 and have stayed democratic since, and the large group of hybrid regimes.

\section{Vulnerable Extraversion Portfolios and Democratic Consolidation}

That the regimes which democratized in the early 1990s have remained democratic derives in large part from the continued vulnerability of their extraversion portfolio and from the capacity of their rulers to benefit from democratization. These regimes remained structurally vulnerable after 1995 and continued to be sensitive to donor demands, however deflated these became. For example, in Benin, President Soglo faced constitutional crises, mutinies, the consequences of the 1994 CFA Franc devaluation, and ongoing strikes and student protests. In Mali (which also faced the CFA devaluation), the Tuareg rebellion continued throughout the Konare and ATT presidencies, keeping the regime fragile and dependent on outside military support (including from the US). Debt servicing also remained contingent on continued donor assistance. In Mozambique, donor conditionality might have increased rather than easing up after the initial transition. Because the country democratized as part of its peace process, donors were possibly initially less demanding and became more conditional in matters of governance after the initial elections, which might have contributed to keeping FRELIMO committed to the reforms. Sao Tome has been called an "unviable state" due to its reliance on external sources of financial support; by 1997 the government depended on external sources for 97.3 percent of its public investment programs and in 1995, net 
official development assistance amounted to almost twice GDP (Frynas et al. 2003:52). In addition, the regime faced strikes and a coup attempt in 1995.

But it is not enough to demonstrate that regimes are vulnerable to explain their democratic performance in an extraversion framework. They must also be able to instrumentalize democracy to their own benefit, for the success of an extraversion strategy is measured by the capacity of incumbents to stay in power. While consolidating formal democratic gains seems particularly risky for elites interested in remaining in power, ruling elites in most of the strongest democratizers were in fact able to either stay in or rapidly return to power under the new democratic dispensations. Indeed, "at the end of 2002, the single party in power before 1989 remained there in 15 of the region's multiparty political systems" (van de Walle 2003: 300). In other words, being able to navigate the formal trappings of democracy afforded them both international support, as they were playing by the new rules, as well as the personal political and economic rewards that come with holding significant positions of domestic power.

Thus, among the strongest democratizers, I find several cases of elites maneuvering their way back into positions of power even after they were removed from office during the initial transition period. Mathieu Kérékou was re-elected president of Benin in 1996 and again in 2001 . $^{20}$ The ruling party from 1975 to 1990 returned to power in Cape Verde in 2001 when it won legislative elections and its candidate, Pedro Pires, became president. In Mali, ATT who had hoped to seize power by force in 1991 but had then to relinquish it under significant donor and social pressure, was back at the helm through elections in 2002 and was re-elected in 2007.

In many cases, democracy became a viable strategy for ruling elites to remain in power and, in some cases, afforded them even more job security. In Mozambique, FRELIMO won the

\footnotetext{
${ }^{20}$ There are other facets to Kérékou's propensity for instrumental extraversion. In addition to his successive commitments to Marxism-Leninism and to democracy, he also converted to Islam in 1980 (following the rise in oil prices of 1979) before becoming a born-again Christian in the 1990s.
} 
elections and never lost power (or the war). Not only did democratization help bring an end to the war, but it also reinforced FRELIMO's territorial control and its power over its domestic opponent RENAMO (see Cahen 2005), while unleashing very significant aid flows in this resource-poor economy, in which more than $50 \%$ of the budget is funded by donors. If anything, FRELIMO reinforced its monopoly of power in the democratic era, particularly after the replacement of Joaquim Alberto Chissano by Armando Guebuza in 2004, who has presided over a return of party precedence over the state (New York Times, 28 October 2009).

In Sao Tome, the former ruling party was again the dominant party in parliament by 1994 and its leader was prime minister. And although Sao Tome has seen frequent changes in parliamentary majorities since 1991, politics has stayed confined to a handful of elites (Frynas 2003: 73-74). In general, the candidates of the major political parties are personally connected, making party turnover less threatening to the small class of elites' access to state resources (Frynas 2003). Politics in Cape Verde similarly has alternated but has been confined to a small group of elites. In fact, Pedro Pires, the current president, was also Prime Minister from 1975 to 1991. In such environments, consolidating democracy is hardly a risky strategy from the perspective of the elites. Finally, in The Seychelles, René never lost the presidency and managed to increase the number of terms he was eligible for. He finally stepped down in 2004.

Democracy also provides ruling elites with material benefits. Although democratic African countries tend to be less corrupt than other countries, they are far from corruption-free and do not necessarily show progress over time in this respect. In Sao Tome, for example, according to Africa Contemporary Record, "corruption and patrimonial politics remained the stock in trade of all political leaders [after the transition] and the only means open to them to win elections" because of a "culture of corruption so deeply implanted in the political system" (XXV B267). In Benin, Nassirou Arifari writes of the continued "extortion" of authorities (2006). As illustrated by Table 2, 
corruption has remained relatively high in most democratic countries (worsening in Malawi, Mali, Mozambique and the Seychelles), which supports an inference that elites continue to appropriate resources and thus find an instrumental interest in maintaining democracy (unfortunately no data on corruption is available for all these countries prior to 1998).

$\begin{array}{lcc}\text { Table 2. Corruption among African } & \text { democratizers } \\ & & 2008 \\ \text { Benin } & -0.7 & -0.4 \\ \text { Cape Verde } & -0.3 & 0.8 \\ \text { Malawi } & -0.5 & -0.6 \\ \text { Mali } & -0.3 & -0.5 \\ \text { Mozambique } & -0.4 & -0.6 \\ \text { Sao Tome } & -0.4 & -0.4 \\ \text { Seychelles } & 0.5 & 0.2 \\ \text { Average } & \mathbf{- 0 . 3} & \mathbf{- 0 . 2} \\ \text { All-Africa average } & \mathbf{- 0 . 6} / \text {-0.6 } \\ \text { Source: http://info.worldbank.org/governance/wgi } & \\ \text { (positive numbers indicate less corruption, range of values is about -2.5 to 2.5; } \\ \text { measure is normalized). } \\ \text { *1996 or first year available. }\end{array}$

The expectation of political and material benefits from democratization is by no means merely confined to African leadership. Wright (2009) finds that democracy-conditional foreign aid is most likely to become the impetus for liberalization in settings where the authoritarian regime's tenure will be least threatened by democratization. These regimes, he notes, find it in their interest to democratize to gain access to foreign finance, while they maintain job security. ${ }^{21}$ Therefore, the consolidation of strong democratizers might be partly explained by their elites' continued instrumentalization of democracy for both political and material benefits. The high level of

${ }^{21}$ Not all of these calculations were precise, however. In some cases, regime's miscalculated whether or not they could weather the initial elections and maintain control over the democratic transition. For example, in Cape Verde, Pedro Pires, the prime minister prior to the adoption of multiparty elections, admitted quite honestly that the PAICV leaders had embraced the idea of democratic transition in part because they were convinced that they could not lose multiparty elections. They however did lose to an opposition party that had formed only eight months prior to the elections (Meyns 2002). 
vulnerability of their portfolio maintains democratic compliance as the only available extraversion strategy. The high rate of incumbency success inherent in the clientelistic nature of African electoral democracies (Chabal and Daloz 1999; Posner and Young 2007; van de Walle 2003) limits the risks of this strategy.

\section{Making Sense of Hybrid Consolidations}

The logic of hybrid consolidation is not all that different. One distinction might be that hybrids remain over time less vulnerable to donor conditionality. They have more access to alternative sources of revenue, are generally less dependent on foreign aid and as a group are comprised of fewer Soviet clients. In addition, donors care relatively less about democracy in hybrid regimes, in part because these countries tend to have resources or strategic advantages that matter more to them. Hence, donor preferences are themselves a function of country conditions. Finally, it might be intrinsically harder for donors to monitor conditionality at mid-levels of democracy, facilitating hybrid consolidation.

To begin with, hybrids are less vulnerable to donor demands than their democratic counterparts. First, fewer of them were initially Soviet clients and thus fewer of them had to scramble to find new patrons (Table 3). In contrast, more of them are in the French sphere of influence. French patronage after the initial transition has not been excessively sensitive to democratic conditions, which gives these regimes some room of maneuver. The ratio of aid to export revenue, a novel measure of the relative importance of aid cash flows to which I return at greater length in the empirical section, is considerably smaller for hybrids than it is for democratizers (a phenomenon also observed during the initial transition). Finally, none of the strong democratizers are significant oil producers whereas $29 \%$ of the hybrids are, providing the latter with some alternative source of revenues. 
Table 3: Comparing selected indicators of vulnerability after the initial transition, Democratic and Hybrid Regimes

\begin{tabular}{|c|c|c|c|c|}
\hline Group & $\begin{array}{c}\text { Soviet } \\
\text { Clients }\end{array}$ & French Clients & Oil Producers & Aid-to-Exports ratio** \\
\hline & \multicolumn{3}{|c|}{ ( $\%$ of regimes within group $)$} & (average $\%$ of indicator within group) \\
\hline Democratizers & 71 & 29 & 0 & 2.75 \\
\hline Hybrids & 41 & 59 & 29 & 0.76 \\
\hline
\end{tabular}

Access to revenue from the export of natural resources no doubt represents one of the most significant linkages in a portfolio which can afford regimes the ability to avoid pressure to democratize. Of the 17 hybrids, eight (Angola, Cameroon, the CAR, Chad, Congo-Brazzaville, Gabon, Niger and Zambia) are large primary commodity producers. As in the initial transition period, these countries benefit from alternative sources of income aside from aid, which shield them from conditionality, irrespective of the direct negative effects that resource abundance per se might have on democracy (Jensen and Wantchekon 2004; Omgba 2009; Ross 2001). Moreover, these regimes also have greater leverage in playing patrons against each other, as they keep patrons competing to gain access to their natural resources. In this respect, the argument that China's return to commodity-rich African countries has lessened the leverage of western donors in terms of governance has already been well debated (Tull 2006; Taylor 2009; Brautigam 2009).

Diversification does not only provide alternative sources of income for a regime. It also allows hybrid regimes to take advantage of the multiple interests that donors hold in their country. Put differently, regimes exploit those elements that are of interest to outsiders and that can buffer them from more substantial democratic reforms. As much as they can, they shape their portfolios so as to maximize their domestic freedom.

Donors might indeed be intrinsically less committed to democracy in countries on which 
they depend for resources and with which they have established routines and privileges (Uvin 1993: 69; Hook 1998). Both the United States and the European Union, for example, failed to implement strict conditions on their aid to Nigeria during the return to military rule in 1993 because of their oil interests in the country (Crawford 1997:91). Such lack of internal consistency might particularly affect France which has a multifaceted involvement in African countries (Nelson and Eglinton 1992:82). For example, the democratization pressure exercised by France on Benin and Mali contrasted with their more lenient attitudes towards Congo-Brazzaville and Gabon. One is also tempted to see a link between the announcement by President Sarkozy in Niamey of significant new French investments in Niger's uranium sector in March of 2009 and President Mamadou Tandja's subsequent authoritarian drift (which led to his overthrow in February 2010).

Donor countries are also increasingly torn between their desire for democracy and their interest in political stability, including containment of alleged terrorist threats. The "war on terror" can also become the object of extraversion. In this respect, the rise of the anti-terrorist agenda after 2001 has offered some African ruling elites (particularly those of the Sahel region and of countries with large Muslim populations) a new venue for extraversion that has reduced the appeal and necessity of democratization. Cédric Jourde (2007:481) finds that Mauritanian and Guinean state elites actively 'enacted a series of performances such as the arrests of alleged 'Islamists,' 'warlords,' and other transnational 'subversive threats,' thereby framing their domestic and foreign policies in ways that can resonate with hegemonic international discourses, seeking to obtain either more support from Western states or to lower their democratization pressure (or both)."

Similarly, the geopolitical importance of some hybrid regimes might be a source of leverage. Since the death of Côte d'Ivoire's President Félix Houphouët-Boigny in 1993, Blaise Compaoré of Burkina Faso has been the new power broker of West Africa, an important relay of French foreign policy. France has also systematically courted the Angolan regime over the last decade, and Angola 
has been involved in both Congolese conflicts in support of France's clients. Ethiopia barely received a slap on the wrist following the large-scale violence in the wake of its botched 2005 elections, in part because it is the US' main ally in the Horn of Africa against Islamic insurgent movements. The same argument also applies to quite a few of the stagnant authoritarian regimes. Western donors generally ignore Uganda's de facto one-party system because of the country's economic growth, success with fighting HIV and its government's support in the "War on Terror."

In addition to the mixed motives of donors, there might be an intrinsic difference in how they value democracy as a function of the degree of a regime's democracy. In other words, with democracy promotion an important dimension of foreign aid agendas since the early 1990s (it accounts for an annual $\$ 2.5 \mathrm{bn}$ in aid in the United States alone $\mathrm{e}^{22}$ ), donors might have too much at stake to contemplate failure among the strong democratizers. They are unwilling to see reversion in these countries, and ready to invest additional efforts to avoid it. In contrast, they have less at stake among hybrid regimes. They are satisfied for these countries to meet a minimum threshold of democracy, but it is not worth the effort to push for more, especially in view of the difficulties to make conditionality successful (Brown 2005: 184-188).

Hence, hybrid regimes face little pressure to further democratize. They get away with some trappings of democracy, while the incumbents remain safely in control of the political process. Yet, they are not at liberty to completely revert to authoritarianism either. Serious setbacks, like largescale political violence against opponents or military coups, carry sanctions. For example, the United States suspended all but humanitarian aid after the Rajoelina takeover in Madagascar in March of 2009. Similarly, France and the European Union applied an arms embargo after the Camara regime in Guinea killed some 150 opponents in a Conakry stadium in September 2009. In contrast, the Democratic Republic of Congo did not face any significant consequences from the

${ }^{22}$ Carothers (2009). 
abductions and killings of human rights activists and journalists in 2008 and 2009, and the US hardly complained about the scrambling of Voice of America by the Ethiopian government in 2010, both of which registered too low on the conditionality scale.

The compatibility of hybridity with democratic extraversion is thus partly a matter of salience. Holding multiparty elections can be easily observed and creates a presumption of relative democracy. In between elections, it takes very significant backsliding to trigger aid sanctions (Brown 2005:184). Actual aid withdrawal is unlikely to happen unless regimes display dramatic and recognizable undemocratic behavior, such as a coup or civil conflict (Boulding and Hyde 2008). As a result, hybridity has stable characteristics.

Hybrids are countries that can capitalize on the inherent weaknesses of political conditionality. They might have more resources or be more important geo-strategically, and they may benefit from the ambiguity of donors' goals and ambitions towards them. Consequently, they were able to limit the degree of their original democratization and to stabilize at such level (or, for a few, to backslide from initially larger gains). Yet, they cannot afford or find few benefits in returning entirely to authoritarianism. For these countries, partial reform is an equilibrium.

\section{Empirical Evidence}

In this section, I use OLS regression analysis to test the explanatory power of the extraversion argument compared to alternative possible explanations of African regime trajectories. I begin with a comparison between a model of transition based on domestic predictors and one based on measures that capture a country's vulnerability to foreign pressure. I then combine both models into one analysis. I then do the same for consolidation. I find that, in both cases, variables that operationalize the extraversion theory provide much greater explanatory power. 


\section{Transitions}

I present the results in Table $4 .^{23}$ The dependent variable to capture the extent of early transition toward democracy is the change in freedom house scores from 1989 and $1995 .{ }^{24}$ All models include a control variable for the freedom house score in 1989. This is a convergence term, which captures the fact that initially more democratic countries have less room for subsequent progress. The first model includes all variables that approximate possible domestic determinants of democratization. Specifically, in the first model, I find no statistically significant effect of the most common predictors of democratization, namely GDP per capita in 1989 , literacy, ${ }^{25}$ ethnic fractionalization (Easterly and Levine 1997), domestic protests (Bratton and van de Walle 1997), colonial legacy (Joireman 2004), or past experience with a multiparty system (which Bates 2008 refers to as "historisis"). ${ }^{26} \mathrm{I}$ did, however, find support for Lindberg's assertion that the practice of elections will be positively correlated with democratization. It should be mentioned, though, that I did not use Lindberg's (2006) own measure of elections, which counts the total number of elections a country has had since its last "breakdown" (coup or civil war), because I was concerned that resetting the elections count after a breakdown might make the measure somewhat endogenous to democratic developments. Instead, I used a cumulative measure of elections that does not reset the

\footnotetext{
${ }^{23}$ For data sources and measurements, see Appendix I.

${ }^{24}$ For all analyses (transition and consolidation) I tested whether the results were robust to using just civil liberties scores and just political rights scores. In general, the results were robust. In all cases, extraversion type variables provide the majority of explanatory power and domestic variables, as a group, are found to not significantly improve the explanatory power of the models.

${ }^{25}$ GDP per capita and literacy are meant to operationalize the effects of a modernization-type democratic movement; wherein industrialization is theorized to promotes economic wealth and correlates with democratic demands. GDP per capita was measured in 1989 to control for whether variations in wealth at the beginning of the wave can account for variations in the extent to which a transition occurred. An average literacy score of the available data for each country over the 1990-2007 was used because of the severe missingness of literacy data and under the assumption and observation that literacy data does not vary dramatically over this period of time.

26 Bates (2008:163) finds that "the longer a country has been subject to a no- or single party system, the less likely it is to change to a multiparty system." For a similar argument applied to Latin America, see Mainwaring and Perez-Linan (2008)
} 
count to 0 after breakdown. ${ }^{27}$ Altogether, the first model is significant only at the $10 \%$ error level (as indicated by the $\mathrm{F}$ test), and a large proportion of its R-squared comes from the convergence term alone.

Table 4: Extraversion, Vulnerability and the Initial Democratic Transition

\begin{tabular}{|c|c|c|c|c|c|c|}
\hline & \multicolumn{2}{|c|}{$(1)$} & \multicolumn{2}{|c|}{ (2) } & \multicolumn{2}{|c|}{ (3) } \\
\hline & Coef. & $\begin{array}{c}\text { Robust } \\
\text { SE }\end{array}$ & Coef. & $\begin{array}{c}\text { Robust } \\
\text { SE }\end{array}$ & Coef. & $\begin{array}{c}\text { Robust } \\
\text { SE }\end{array}$ \\
\hline Freedom House score in 1989 & $-1.49 * * *$ & 0.43 & $-0.52 * *$ & 0.24 & $-1.09^{*}$ & 0.61 \\
\hline GDP per capita in $1989, \ln$ & 0.13 & 0.29 & & & 0.39 & 0.39 \\
\hline Average Literacy rate, $1990-2007$ & -0.75 & 0.69 & & & -0.38 & 0.78 \\
\hline Ethnic Fractionalization & -0.56 & 0.95 & & & 0.16 & 1.22 \\
\hline Protests & -0.03 & 0.03 & & & 0.00 & 0.04 \\
\hline Legacy & 0.27 & 0.32 & & & 0.02 & 0.40 \\
\hline Historisis & -0.04 & 0.04 & & & 0.03 & 0.04 \\
\hline Elections & $0.64 * *$ & 0.31 & & & $0.75^{*}$ & 0.42 \\
\hline Soviet & & & $1.36^{* * *}$ & 0.46 & $1.54^{* *}$ & 0.70 \\
\hline French & & & $0.75^{*}$ & 0.42 & -0.12 & 0.70 \\
\hline Aid as a $\%$ of exports, $1989-95$ & & & 0.08 & 0.06 & $0.11^{* *}$ & 0.05 \\
\hline Oil Rents, 1989 & & & $-1.18^{* *}$ & 0.54 & $-1.62^{*}$ & 0.89 \\
\hline SAL to 1989 & & & -0.15 & 0.11 & -0.06 & 0.15 \\
\hline Conflict 1989-95 & & & $-0.86 * *$ & 0.39 & -0.31 & 0.55 \\
\hline Constant & $6.39 * *$ & 2.75 & $2.29 * *$ & 0.88 & 0.06 & 4.07 \\
\hline Observations & 43 & & 46 & & 42 & \\
\hline R-squared & 0.30 & & 0.46 & & 0.60 & \\
\hline F test & 1.87 & & 7.40 & & 6.74 & \\
\hline Prob $>$ F & 0.10 & & 0.00 & & 0.00 & \\
\hline
\end{tabular}

OLS; Robust standard errors in parentheses *** $\mathrm{p}<0.01, * * \mathrm{p}<0.05, * \mathrm{p}<0.1$ (two-tailed)

In contrast, the second model, which estimates the effects of extraversion and vulnerability, has good predictive power and several significant variables. It shows that having been a Soviet or French client significantly promoted democratic transition when these patrons disappeared or relented. I test whether access to foreign aid has an effect on this early transition period with the use of foreign aid as a ratio of export revenue on reform. Most studies that have looked at the impact of aid dependence on democratization have measured it per capita or as a percentage of GNI

\footnotetext{
${ }^{27}$ In an unreported model I used a measure that I think approximates Lindberg's (2006) measure of the number of elections. In that model, elections is also significantly and positively associated with democracy.
} 
(and most have not found any significant effect). This is a poor proxy for the role of aid in extraversion strategies, however. From the point of view of incumbent elites, one of aid's main benefits is access to cash. The extent to which such access matters to a regime is a function of what other sources of cash it can rely on. Measuring aid as a percentage of GNI does not capture this measure of necessity. Two countries can have identical aid ratios to GNI. Yet, one country's GNI might rely largely on exports and thus provide ample cash, while another might depend more on subsistence farming and thus present governments with fewer avenues for access to foreign exchange. Aid would be more important in the extraversion portfolio of the latter country. This measure, averaged over 1989-1995 period, captures the relative importance of aid cash during the period in question for the country. It draws sharp distinctions.

In addition to these three measures of extraversion, I include three factors that might reduce a country's vulnerability. Access to oil rents at the beginning of the transition (1989) is found, as expected, to negatively impact democratization during this period and is interpreted to imply that this lack of vulnerability at the onset of the transition buffered the regime from future democratic demands. I also reasoned that countries that had access to IMF structural-adjustment financing prior to 1989 (which did not include governance conditionality then, much less democratic ones) might have been in lesser dire straits than others and more immune to the democratic demands of Western bilateral donors. However, while the coefficient is in the right direct, it is not significant and thus, this idea was not supported by the results. Finally, I find a negative effect of conflict on democratization. No doubt this is at least in part a direct effect: countries in the throes of war are less likely to democratize. But it also, paradoxically, mitigates the democratic vulnerability of a country towards donors: countries that experience conflict are under less pressure to democratize from donors. Altogether, the second model is significant at the $0 \%$ error level and accounts for almost $50 \%$ of the variance. 
Finally in the third model, I test a combination of all variables. In this model, the elections effect remains; elections are found to be positively associated with the extent to which a regime liberalized during the early 1990s. Additionally, conflict and being a former French colony is no longer significant in the combined model. However, this model illustrates that extraversion type variables still tell the majority of the story. For instance, being a Soviet client and having less access to oil rents is still robustly associated with more democratization during this time period. Also, with the inclusion of domestic variables, a country's dependence on foreign aid is also found to be significantly and positively influential on the extent to which regime liberalizes. In addition, I ran Ftests on each group of variables (domestic and extraversion) after the combined model was analyzed. These tests determine whether the inclusion of a group of variables significantly improves the variance explained of regression analyses that would otherwise exclude them. I found that the group of domestic variables do not significantly improve the variance explained, while the group of extraversion variables do. These tests serve as an additional way to confirm that extraversion type variables provide most of the explanatory power in the pre-1995 transition period in Africa.

\section{Consolidations}

Extraversion also proves to be an essential driver of regime consolidation. In Table 5, I again put side by side a model based on domestic explanations of regime consolidation (measured this time by average Freedom House score for 1996-2009), one based on extraversion, and a combined model. Because I use the extent of the initial transition as a predictor of subsequent consolidation, I exclude countries that were already democratic prior to 1989. I also omit Namibia and South Africa, which had more radical regime changes that make their transitions not comparable.

In all three models, I control for the effects of initial change (1989-1995). As discussed in the first section, the initial change in civil liberties is a strong predictor of subsequent levels of 
democracy. Aside from that and from "historisis" (the number of years spent as a single party

before the transition has a negative effect on the subsequent level of democracy), however, none of the common domestic factors is significant, including the elections effect found in the previous analyses. ${ }^{28}$

In contrast, the second model supports the hypothesis that continued vulnerability of extraversion portfolios largely contributes to regime consolidation. The relative parsimony of this model derives from several factors. First, I found no effect of being a former French colony or Soviet client, and did not include them in the model (which had no effect on the other variables). This is not surprising: as the decade wore on, French enthusiasm for democratization waned and former Soviet clients aligned with new donors. I did not either include the measure of structural adjustment loans that we had in table 5. I actually found a significantly positive effect on democracy of the number of structural adjustment loans (SALs) between 1995 and 2008. Including this variable had no effect on the sign, magnitude and significance of the aid as $\%$ of export variable, but it slightly reduced the significance of the conflict and oil variables. Its positive sign, compared to its negative effect in the transition regression (Table 4), is not either necessarily surprising, as SAL's impact on regime type became more ambiguous throughout the 1990s. In some countries, SALs' conditionality took on more political dimensions (in fact, many of these loans became public-sector adjustment and poverty-reduction strategy programs) and the multilateral agencies worked more synchronously with bilateral donors.

\footnotetext{
${ }^{28}$ When my measure of elections is substituted with a measure of elections that I think Lindberg (2006) used in this model, the number of elections is significantly and positively associated with regime consolidation in the 1996-2009 period. However, because of the issues discussed above with how the variable is originally operationalized (reset for a democratic 'set-back') and how this might be endogenous to the dependent variable, I chose to not report that model.
} 
Table 5: Extraversion, Vulnerability and Regime Consolidation

\begin{tabular}{|c|c|c|c|c|c|c|}
\hline & \multicolumn{2}{|c|}{ (1) } & \multicolumn{2}{|c|}{$(2)$} & \multicolumn{2}{|c|}{ (3) } \\
\hline & Coef. & $\begin{array}{c}\text { Robust } \\
\text { SE }\end{array}$ & Coef. & $\begin{array}{c}\text { Robust } \\
\text { SE }\end{array}$ & Coef. & $\begin{array}{c}\text { Robust } \\
\text { SE }\end{array}$ \\
\hline Freedom House Score Change 1989-95 & $0.50 * * *$ & 0.10 & $0.41 * * *$ & 0.08 & $0.45^{* * *}$ & 0.07 \\
\hline GDP per capita in $1995, \ln$ & 0.10 & 0.20 & & & 0.19 & 0.16 \\
\hline GDP growth average 1995-08 & -0.02 & 0.04 & & & & \\
\hline Average Literacy rate, $1990-07$ & -0.41 & 0.46 & & & -0.08 & 0.44 \\
\hline Ethnic Fractionalization & 0.34 & 0.55 & & & $1.15^{*}$ & 0.61 \\
\hline Legacy & -0.08 & 0.22 & & & -0.23 & 0.24 \\
\hline Historisis & $-0.06 * * *$ & 0.02 & & & $-0.04 * *$ & 0.02 \\
\hline Elections & -0.04 & 0.08 & & & 0.01 & 0.07 \\
\hline Aid as a $\%$ of exports, $1996-08$ & & & $0.17 * * *$ & 0.06 & $0.17 * *$ & 0.07 \\
\hline Oil Rents, 1995-06 & & & $-0.86 * *$ & 0.39 & $-1.04 * *$ & 0.41 \\
\hline Conflict 1995-08 & & & $-0.86^{*}$ & 0.27 & -0.40 & 0.36 \\
\hline Constant & $5.49 * * *$ & 1.69 & $3.25^{* * *}$ & 0.26 & 2.67 & 2.12 \\
\hline Observations & 40 & & 41 & & 40 & \\
\hline $\mathrm{R}$-squared & 0.50 & & 0.62 & & 0.66 & \\
\hline F test & 5.29 & & 17.30 & & 10.87 & \\
\hline Prob $>F$ & 0.00 & & 0.00 & & 0.00 & \\
\hline
\end{tabular}

OLS; Robust standard errors in parentheses

${ }^{* * *} \mathrm{p}<0.01,{ }^{* *} \mathrm{p}<0.05,{ }^{*} \mathrm{p}<0.1$ (two-tailed)

The analysis focuses therefore on the three remaining variables. The notion of vulnerability of extraversion portfolios is largely borne out by the behavior of aid in $\%$ of export, which has a very significant positive association with levels of democracy, highlighting democracy's role as a cash earner for governments deprived of others sources of foreign exchange. Even after the initial transition, strong democratizers remain about four times more dependent on foreign aid cash than their hybrid and authoritarian counterparts. Looking then at what mitigating circumstances might reduce the vulnerability of countries and the necessity of democracy for their regimes, I observe that rents from oil exports have a significant and negative association with democracy. Oil exporters are on average over 1.5 points below other African countries in terms of their freedom house scores. Finally, the existence of conflict is once again associated with less democracy. As before, such a finding only partly relates to the extraversion argument, for countries at war make for poor democratic venues in general.

I was, however, unsuccessful in my attempts to capture some of the non-financial specific 
conditions that might reduce the vulnerability of hybrid consolidators. For example, I found no effect of a dummy variable measuring whether a country was a strategic ally of France (Angola, Chad, Central African Republic, Côte d'Ivoire, Djibouti, Gabon, and Senegal) or of the US (Angola, Djibouti, Ethiopia, and Kenya), or benefited from some other circumstances that might reduce donor pressure (Rwanda, Uganda), including a perceived role in the "fight against terror" (Mali, Mauritania, Niger). I believe, however, that such absence of significant effect largely derived from the lack of nuance of these dichotomous measurements and the problem of multiple overlapping variables with few observations.

The combined model, despite a few changes, provides a confirmation of much of the previous two. Extraversion type variables still provide most of the story. Although conflict is not longer associated with consolidation, oil and aid dependence prove to be robust indicators of consolidation. With regard to domestic variables, while historisis is found to be positively associated with consolidation, so is ethnic fractionalization. This is surprising and counterintuitive to the theory that ethnic fractionalization squelches collective action, which is needed for democracies consolidate. Once again F-tests were performed to examine the importance of each group of variables to the variance explained. As with the transition model, I find that the group of domestic variables to do not significantly improve the explanatory power of the consolidation analyses, while the group of extraversion models do to the $0 \%$ error level.

\section{Conclusion}

Variations in initial transitions to democracy and in subsequent consolidations at different levels of democracy can be largely accounted for by variations in the degree of vulnerability of the extraversion portfolios of African regimes. Regime consolidation at the level of democracy reached

at the end of the transition period typically results from an absence of major changes in extraversion 
portfolios. This is not to say, however, that such changes cannot take place and that consolidation might not give way to new transitions - towards more or less democracy — in any given state. On the contrary, one should expect portfolios to evolve in the long run as different endowments acquire or lose value. The end of the Cold War provided a rapid and dramatic example of such a shift (with socialism suddenly losing extraversion currency), but slower adaptations are more likely. Recent developments suggest that portfolio diversification might be on its way for several countries, for which democracy would then represent relatively lesser value. These developments include increased Chinese patronage for several regimes (although this effect might not be clearly differentiated from the mineral rent as it mostly concerns resource-rich countries); the discovery (Ghana, Uganda) or start in production (Sao Tome) of oil; and new strategic importance in the context of the US “war on terror” (e.g., Kenya, Mali, or Mauritania).

If African democracy is more a function of access to external resources than it is of domestic factors, one might wonder how genuine it is. When democratic reforms are taken primarily for a foreign, rather than a domestic audience, does it decrease the many other dividends we expect to come from democratization? Are citizens able to use democratic institutions adopted under these "exogenous" circumstances to hold their leadership accountable for providing social services? In the next chapter I return to addressing the puzzle that democratic change has not been associated with positive change in social service coverage. I develop an argument that focuses on the likely negative implications that foreign sourced democratic change has on institutionalizing responsive leadership. Put differently, I argue that it is the exogeneity of Africa's democratic wave that can explain why Africa's newest democracies are failing to provide higher levels of social services. 


\section{Chapter Three: Exogenous Political Change and Government Responsiveness}

This dissertation focuses on examining why the 1990s democratization wave in Africa has not been associated with increases in social service coverage. In the previous chapter I argue that Africa's post-Cold War democratization wave was largely a product of the extraverted nature of African politics and a changed international environment wherein foreign pressure to adopt democratic institutions became dominant. In this light, steps to democratize can be both seen as a strategy of extraversion and a consequence of it. Regimes were not only under immense pressure to adopt democratic institutions to maintain ties or obtain new linkages with foreign patrons, they were equally faced with a new set of incentives to democratize. Thus, much of Africa's 1990s democratic wave can be attributed to changes in exogenous, or foreign, circumstances, rather than from pressures generated from a domestic democratic movement. As illustrated in chapter 1, even though the majority of authoritarian regimes on the continent adopted democratic institutions, like multiparty elections, these reforms have not been associated with a rise in responsive leadership, as is indicated by the state of social services coverage on the continent. In this chapter I develop an argument that contends that it is the exogenous nature of political liberalization which can help to explain why democratization has become disassociated with social service coverage on the continent. I argue that instead of institutionalizing an electoral incentive to provide social services, leadership of exogenous democracies become principally accountable to the foreign actors whom political change was meant to appease. However, while foreign actors can, to some degree, monitor whether African leaders hold multiparty elections, they are less able and, in some respects, unwilling to effectively demand and monitor that regimes adopt political reforms that are necessary to institutionalize a responsive democracy and to supervise their habitual behavior in terms of service delivery. Additionally, exogenously pressured democratic reforms are likely to result in an imbalance 
between the ruling party and domestic opposition. In such settings, domestic opposition parties are usually under-prepared to effectively act as a democratic watchdog and the ruling party is able to maintain and/or create a political monopoly wherein the democratic playing field is tilted. These outcomes ultimately threaten any electoral incentive a ruling party might have to produce higher levels of social services.

To test the merits of the broader claims of this argument, I develop a measure of exogenous political change and examine its impact on social services in Africa through quantitative analyses. In using this measure in standard econometric models of the relationship between political change and changes in social services, I illustrate that exogenous political change has dampened the impact that democratic progress has had on social service delivery on the continent. Further, I illustrate that once these models account for the exogeneity of political change, democratization in Africa is associated with positive changes in quality of life. These findings directly address the empirical puzzle uncovered in chapter one of this dissertation.

\section{Exogenous Democratic Change and Responsive Leadership}

That democracies vary, or that such variation likely produces important policy differences across countries is not a novel idea. Little, however, has been written on the lasting impacts of different paths that countries take to democratize. This chapter focuses on the likely lasting impact that different transitions have on policy outcomes. Specifically, democratic reforms are conceptualized to exist along a continuum based on the importance of various pressures and incentives that were present to persuade undemocratic regimes to adopt them. Pressures or incentives to reform are conceptually categorized as either domestically rooted, or externally driven. Thus, at the end of the continuum would be those regimes that adopted reforms primarily due to circumstances that were external to the country, which I will call exogenously derived 
democratization. These regimes may have had internal demands for democratic reforms as well, but the principal impetus behind the concessions was due to foreign pressure or external circumstances. At the opposite end would be those where domestic pressures, or endogenous pressures, were most important to the decision to reform. Reforms that were taken due the importance of an equal mixture of both would make up the middle point of this continuum. Thus, conceptually, this continuum does not capture the mere presence of one type of pressure or another, but their relative importance to the regime's decision to ultimately adopt reforms.

Regardless of what mixture of exogenous and endogenous factors contributed to a decision to adopt multipartyism, if a given government holds competitive elections, should we still expect that leadership will be incentivized to meet the social service needs of their constituents because of their fear of being voted out of office? (Deacon 2003; Lake and Baum 2001; Bueno de Mesquita et al. 2003; Ghobarah, Huth and Russett 2004; Meltzer and Richard 1981). I argue that instead of institutionalizing an electoral incentive to provide social services, leadership of exogenously derived democracies are unlikely to adopt policies which institutionalize a more responsive political system. This problem is a result of two different spheres of possible influence on a government, the domestic and international. Exogenous democratization inherently shifts accountability of the government from the domestic to international sphere. In the domestic sphere, incumbent leadership are largely unchecked as they do not face strong opposition to a continuation of the old way of doing things, and will thus have ample leeway to protect a status quo which has thus far benefitted them. However, internationally, the foreign actors for which political change was meant to appease are equally unlikely and/or unable to use their economic and other leverages to effectively cause ruling elites to adopt "responsive" policies. While donors ensure a change towards democracy occurs, it is unlikely to be one that increases a government's level of responsiveness to its people. Thus, exogenous democracy in Africa ends up introducing a wedge between the formal 
characteristics of a regime and its practical dimensions, its manifestations in the daily lives of its citizens.

Donors' Role in Establishing a Responsive Government

In Africa's more exogenously derived democracies, foreign aid donors were the main audience for which democratic reforms were taken. While changes made in this setting may have not had strong domestic roots, donors still hoped that newly elected governments would be accountable to the demands and needs of the domestic public (Crawford 2001: 78). However, increasing a government's responsiveness involves ensuring that several complex policy and social changes take place, which require the attention of change seekers far beyond the first multiparty election. When donors are the primary actors for which steps toward democracy are taken, the degree of responsiveness the ensuing democracy will have depends primarily on the ability and will of donors to compel recipient governments to become committed to policy changes associated with responsiveness. Donors have a set of instruments available to them to try to shape a recipient government's incentives to make domestic change (Crawford 2001:44; Carothers 1999: 6). They can either sanction or reward behavior, as is often done through withholding or increasing foreign aid and other assistance. They can also directly fund actions that they feel will strengthen democracy in a given country; such assistance is the most common tool used to promote democracy (Carothers 1999:6). Below, I argue that donors are unlikely to use these tools effectively to ensure that changes which are associated with increases in responsiveness take place. It is doubtful that donors will use sanctions on a new democracy, or otherwise, for the specific goal of increasing responsiveness. Additionally, rewarding governments for, or directly funding policies, aimed at institutionalizing a more responsive democracy often does not overcome a lack of domestic will to change the status quo or pre-existing socio-economic realities which inhibit the establishment of increased responsiveness. 
Arguably, punishing an economically dependent recipient country by withdrawing aid or other needed assistance is a donor's most powerful tool. While a donor could sanction a government if it did not take measures that would theoretically institutionalize a higher level of responsiveness, as mentioned in chapter two, aid sanctioning is usually reserved for times where easily recognizable and egregious signs of democratic backsliding occur, like in the case of a coup or civil conflict (Boulding and Hyde 2008). Sanctioning is probably reserved as a reaction to dramatic events for several reasons. For example, donors may want to avoid the sheer expense and disruption that accompanies canceling development projects, for example, which usually require long term planning, and consistency to have a lasting impact (Brown 2005:84). Additionally, as Easterly (2002) has made apparent, the aid bureaucracies that are delegated with evaluating aid programs and making many decisions about the allocation of aid, have strong incentives to not to reduce its flow, or recommend a reduction to other decision makers, because cutbacks can cause fluctuations in their own operating budgets.

However, there are additional reasons, specific to the task of trying to induce more responsiveness that decrease the likelihood that aid withdrawal be used for this purpose. For example, because "responsive" policy changes are likely to be complex undertakings, measuring whether a policy change has increased responsiveness is difficult to do (Uvin 1993: 70; Hook 1998: 173). Thus, donors may have a difficult time establishing a benchmark with which they might be satisfied or dissatisfied in order to take action (Brown 2005). This problem of operationalizing responsiveness success is illustrated with the case of decentralization. A decentralizing government is supposed to open more effective channels for citizens to voice their policy demands (Tommasi and Winshelbaum 2007), incentivize local policy makers to respond to local needs and aid in rectifying a general problem of inequalities in the distribution of state resources (Faguet 2004; Besley and Coate 2003: 2628; Bardhan and Mookherjee 2005). However, decentralization alone does not guarantee 
responsiveness, and in some cases it can result in concentrating power in the hands of local elites (Edwards 1994: 69). herefore, where measures to decentralize are taken, donors have to be able and willing to monitor the development of a democratic, or responsive, character of local government, as well (Crawford 2001: 84). Such monitoring not only requires an incredible commitment from a given interested donor, but judging whether progress has been made on this front will likely be complicated by a host of other qualitative measurement and contextual factors. The complexity of evaluating whether a given policy, like decentralization, induces responsiveness makes conditioning aid on this goal highly unlikely.

The example of decentralization highlights other factors that undermine the willingness of donors to demand that governments adopt policies which increase responsiveness. Donors might avoid promoting institution altering policies, like decentralization, with too much force because such pressure could raise controversial issues of the sovereignty of the recipient government to determine the structure and nature of its own political system (Crawford 2001: 84). Additionally, promoting decentralization, or any responsiveness-associated policy, may conflict with other policy goals a donor may have an already, or more, vested interest in. Particularly in the case of decentralization, a donor may be reluctant to push for shifting roles and responsibilities of the central and local governments if there is also an effort being made to persuade the government to follow some sort of "state-shrinking" economic reform agenda (Crawford 2001: 84). As Stephen Brown observed, especially among multilateral donors, economic concerns like this often trumped democratic ones (2005: 186). Operating within competing donor agendas, recipient governments can use a combination of reforms to lessen the attention on any one in particular. If recipient governments take steps to meet the desired economic reforms and make somewhat minimal democratic concessions, donors are more likely to soften political conditionalities on aid, without the promise of more substantive political change. This scenario occurred in the cases of Ethiopia, Ghana, Uganda, 
Kenya, and Zambia, among others (Brown 2005: 185). Among competing agendas democratization is not often the first priority of donors, much less the degree of responsiveness or quality of the democracy that is being promoted.

Beyond sanctioning, donors can also directly fund reform or reward countries for reforming towards more responsive governance. However, in their own right, these "positive" tools are unlikely to be effective to provoke governments to make responsive change, especially when such change threatens the power of those in office. Donors and IFIs are often confronted with a lack of political will among power holders in the recipient government to becoming committed to the reforms they promote (Carothers 1999: 183). This is many times the case when donors try to assist in strengthening legislatures. Stronger legislatures are commonly hypothesized to increase government accountability to its citizens and among government branches (Crawford 2001: 84; Barkan et al. 2004), and such accountability should induce a higher degree of government responsiveness (Crawford 2001: 84). Donors and IFIs have promoted stronger legislatures through a number of measures, from paying for office equipment and training seminars to helping to establish legislative offices and strengthening committees (Stapenhurst 2008: 61). However, while governments find it easy to ask members to attend a training session or allow a new bureaucratic office to open, real change is not usually adopted because power holders are not willing genuinely accept measures that would check their own authorities (Carothers 1999: 88).

Finally, donors, regardless of the tools they use to promote change, may be unable to overcome pre-existing social and economic realities which hinder the establishment of a responsive government. This point is made through the example of civil society promotion. Democracies are likely to be more responsive when domestic civil society is able to channel citizen interests and demands to government and when civil society takes on a role of an autonomous democratic watchdog, which is able to provide a counterweight to state power (Crawford 2001: 21).While 
donors can monitor and sanction the degree to which a government allows civil society to flourish, their attempts in funding the emergence of civil society to act as a check on state power is complicated by the resulting financial dependence of these organizations on donors. Donors try to encourage the growth of civil society through directly funding the operations of an astounding number of local NGOs in Africa, however, in most cases, local NGOs in Africa are too poor to operate without the finance from donor agencies (Diamond 1997: 28). Financially dependent NGOs are unable to evolve organically and independently, because they find that they have to adjust their political and social agendas to suit those of their benefactors (Makumbe 1998: 314). In this manner, "local" NGOs become somewhat of an extension of their foreign donors. This is worrisome for the establishment of a responsive democracy for at least two reasons. First, civil society, or at least the portion of "civil society" that consists of the operation of local NGOs, is domestically unsustainable and would fold if a donor loses interest in funding it. Second, dependence on foreign sources of finance likely decreases an organization's proclivity to act as an effective critic of the government. Donors are often reluctant to offer funding to organizations that make overt political demands of the government because of a worry that their own presence in the country would be expelled in retaliation (Makumbe 1998: 315). Thus, when dependent on foreign finance, local organizations might shy away from efforts at holding elected officials accountable and avoid taking a strong stance to ensure responsiveness. ${ }^{29}$

It is also unlikely that donors will be able to change some of the fundamental socioeconomic structures in Africa that inhibit the natural growth of a more organic and larger class of civil society. Africa's democratization took many scholars by surprise simply because it lacked an

\footnotetext{
${ }^{29}$ Another point to consider here is that donors often fund service delivery NGOs, which provide social services. In other words, these organizations replace the role of the state. This may also be detrimental to establishing a democracy which is responsive to citizens social service needs because citizens may stop expecting the government to provide these services, and, thus, not weigh in a politician's performance on providing services when they vote. This, too, decreases the likelihood that politicians will be incentivized to provide services.
} 
emerging middle or capitalist class whose domestic financial and political leverage was independently derived of the state (Joseph 1997: 363). As discussed in chapter 2, modernization theorists understood a middle class to be pre-requisite of internally driven democratization. Instead, as Peter Uvin observes, politics in Africa is usually contained to "a very small percentage of the population; the large, 'silent majority' - farmers, urban poor- are totally excluded from that' (1993: 73). With few resources, the poor in Africa focus their energy on navigating survival, not political development. These realities are likely to remain untouched by the presence of donor supported democratization efforts.

Domestic Political Environment in Exogenously Derived Democracies

In countries where exogenous circumstances are most important to the decision to adopt democratic reforms, domestic movements or opposition to the ruling party are weak and effectively non-existent, by definition. Thus, domestically, decisions to take steps towards democracy are almost isolated to the purview of the ruling party and/or incumbent. As one observer noted of the case of Guinea-Bissau, where multipartyism was adopted without a significant domestic movement and largely to court Western donors after the regime lost its connection to the Soviet Union at the end of the Cold War (Ferreira 2004), “accepting multi-partyism independently of any popular pressure at least means that the process is protected from the disturbances and unrest inherent in any change dictated by the street" (ARB 1990: 9685). The extent to which a regime can control the terms of political liberalization benefits their ability to institutionalize "rules of the game" which will most serve their own interests. And, because of a lack of organized domestic opposition, exogenous democratizers take transitional steps within an environment which is ripe for them to control.

Some regimes, like Equatorial Guinea, Ghana, and Tanzania, used their domestic control of the timing of the first election to edge out the possibility that an opposition to their continued rule to could effectively mobilize (Hughes 1996; Jeffries and Thomas 1993: 33; Sandbrook 2000:27). In 
each case regimes held elections very quickly after it became clear to the ruling elites that the government lost or might lose needed foreign aid if they did not hold elections and in the case of Equatorial Guinea, specifically, the regime held the first election six months sooner than had been previously announced (Hughes 1996: 442). Many other tactics were employed by regimes to tilt the electoral playing field in their favor. For example, regimes denied opposition parties' access to publicly owned mass media and the freedom to hold rallies, co-opted opposition leaders, used state resources to subsidize their own campaign, deployed militias to intimidate opponents, channeled state resources as patronage towards supportive constituencies, gerrymandering districts to their favor, among other things (Sandbrook 2000; Joseph 1997; Jourde 2007; Schedler 2002:44). In Ghana, the incumbent, facing a weak and fractionalized opposition, was able to walk away from negotiations, with the opposition, with the power to effectively dictate electoral rules and even arrangements of the international supervision over the election (Jeffries and Thomas 1993: 333). While these tactics certainly threatened the freeness and fairness of a first election, they also generally flew under the radar of what the international community could or were willing to monitor and sanction (Levitsky and Way 2006: 382).

In exogenously derived democratic transitions, the cracks in donors' political conditionalities and the lack of a powerful domestic source of pressure at home gave incumbent governments loose parameters within which to operate. This position of control for the incumbent government over the transition in the domestic sphere has an important implication: the incumbent government is in a position to protect much of the status quo, from which they previously benefitted. Thus, in this setting, changes that are adopted during a transition to multipartyism are likely to be done carefully so as to protect the ruling class's access to power. For example, in Equatorial Guinea, where donor pressure resulted in the introduction of a new constitution which legalized opposition parties, the government also codified within that constitution an automatic immunity for the president from any 
prosecution, as well as age (over 40), residency (last five years in the country), income (deposit of 3 million CFA), legal (no criminal record) and nationality restrictions on those who ran for president (Hughes 1996: 445). This was extremely restrictive to the main opposition leaders to the regime, whom had either spent considerable time in exile or had been arrested for political activities in the past (Hughes 1996:445).

A similar move was made in the Gambia, where a military coup, led by Yahya Jammeh, overthrew a long established democratic system in July of 1994 (Wiseman 1998: 65). In October of that year, Jammeh announced that he would stay in power without elections for another four years (Wiseman 1998: 66). However, international donors used their considerable leverage over the regime to speed up the process by sanctioning aid flows and in response, only two months later, Jammeh announced an shortened 2 year transition period (Saine 2002: 168). However during the transitional process, donors did little regarding the regime's attempts to tilt the playing field in its favor. Jammeh was able to push through a new constitution which effectively banned any pre-coup parties from competing (Schedler 2002: 42)..$^{30}$

In addition to making changes carefully, incumbent leadership will likely not make any change which is not demanded of them by the international community. Donors are unlikely and somewhat unable to use their leverage to overcome a problem of a lack of genuine political will to reform. If prior to the transition, the executive branch held an inordinate amount of power, as was the case in many of Africa's personal regimes, the executive branch is likely to remain dominant. Cameroon, the Gambia, Mauritania and Togo can all serve as examples of this sentiment. In each country governments were under extraordinary international pressure to adopt multiparty elections, and due to a lack of organized domestic opposition, the elites within these governments largely

\footnotetext{
${ }^{30}$ While the constitution was also approved overwhelmingly by the public in a referendum, the government made the document public only four days prior to the vote, which did not allow Gambians enough time to really understand the content of what they were voting for outside of the fact that the new constitution allowed for some sort of multiparty democracy (Adejumobi 2000).
} 
controlled the scope of the transition towards multipartyism (Gros 1995; Saine 2002; Pazzanita 1999; Nwajiaku 1994). In the new electoral setting, the office of the president remained dominant without any effective mechanisms to check his power institutionalized (van de Walle 2002: 68). Likewise, if state resources were commonly channeled to patronage networks in the old regime, it is also unlikely that in a new regime the government would adopt reforms which will institutionalize their usage to fund broad based social services. That certain institutions post transition are likely going to resemble institutions of the past is not in any way unique to the experience of only exogenously derived transitions. However, the point I want to emphasize here is that this is especially likely in exogenous democracies, where leadership face few if any organized checks to their power domestically. Thus, democracy, in this setting, will likely resemble much of the old order, with a few cosmetic changes to reflect the acceptance of new formal rules.

Additionally, a tilted balance of power in favor of the existing ruling party in the domestic sphere, is likely to settle into somewhat of an equilibrium. By manipulating the political field at home to retain political dominance, and still fulfilling some democratic demands that came from abroad, incumbents and their ruling parties maintain an upper hand in the initial elections against opposition groups, and winning initial elections further benefits them in subsequent elections, as these parties keep their access to state resources and control of state apparatuses. If we accept that most transitions to multi-partyism which occurred during the post Cold War era in Africa were heavily influenced by exogenous pressure and circumstances, we can find evidence of the legacy of this control in the fact that "at the end of 2002, the single party in power before 1989 remained there in 15 of the region's multiparty political systems" (van de Walle 2003: 300). Additionally, from 1990 to 2005 , in 25 of 46 African countries, the majority party in the legislature won more than $2 / 3$ of the vote and in 21 of those countries they won 75 percent (Manning 2005: 709; Nohlen et al. 1999). The dangers of continued one party dominance, with respect to the institutionalization of a 
responsive democracy, are obvious; when ruling parties enjoy an effective monopoly of power they will have less incentive to undertake real change which will result in a more responsive redistribution of resources towards constituent needs because they will not perceive their seat in power as being credibly threatened by an opposition.

A final point to make here concerns some possible implications exogenous democratization might have on the domestic party system development. At the same time that an exogenous democratization creates a foundation wherein the incumbent has extraordinary control over the ensuing political field, it also likely impacts party formation in a way that further discourages gains in responsive governance. As Carrie Manning has observed, party systems in many African countries are not built on the same foundation that party systems in advanced industrial democracies were (2005). The rise of party systems in most of Europe, for example, is usually explained as being a response to socio-economic development generated from the Industrial Revolution (Huntington 1968). Having been born out of economic change, parties functioned as an organizational tool to channel the political activity of groups with different economic interests (Huntington 1968). However, in the context of Africa's most recent wave of democratization parties really arose once their organization was legal. Thus, as Manning articulates, the party systems that arose in many African countries were not born out of a bottom-up popular organic process, but “out of elites' urgent need for electoral vehicles which would allow them to compete in the newly devised rules of the political game" (2005: 715). Partly as a result of the sense of urgency by which elites organized political parties, parties proliferated in number. For example in Mali, 47 parties initially registered for elections, while in Zaire there were 200 (Bienin and Herbst 1996: 28). Additionally, elites found it much easier to mobilize party followers along pre-existing cleavages, like ethnicity, rather than along ideological differences (Manning 2005). Thus, instead of reflecting a range of policy options, many of Africa's party systems are often described of being void of ideology, giving potential voters 
no real policy options, and more reflective of regional or ethnic differences within countries (Bienin and Herbst 1996: 28; Manning 2005; van de Walle 2003: 298).

While the above scholars did not make these observations about party development specifically or exclusively in countries that I would refer to as "exogenous democracies", I argue that it is reasonable to assume that these characteristics hold most strongly in an exogenously derived democratic setting. Where a domestic opposition is weak or non-existent prior to a regime's concession of a multiparty system, most oppositional mobilization will occur as a response to the legalization of political parties and the announcement of multiparty elections. To the extent that a lack of ideological differentiation and the dominance of ethnicity in Africa's party systems are due to the post-hoc nature of party system development that Manning (2005) describes, one would also expect these characteristics would be particularly pronounced in exogenous democracies. The implications of a party system growing in such a rash environment for institutionalizing responsiveness are grave. When political parties do not represent clearly defined alternative policy options, voters cannot use their vote to voice their demand for policies which are more responsive to their needs.

Thus far I have argued that exogenously pressured democratic reforms are unlikely to institutionalize responsive governments. In these countries, instead of reforming political norms and institutions to become responsive to the social service needs of their citizenry, leadership is more likely to make only the democratic changes that are demanded of them from exogenous actors. Put differently, reforms taken under these circumstances largely impacts the formal institutions of selecting leadership, but does not reduce the distance between the public and elected politicians, which is needed to achieve gains in responsiveness. Exogenous actors, like international donors, are usually ineffective and/or unwilling to use their leverage over the transitioning regime to force changes needed to increase accountability and responsiveness. Domestically, ruling parties generally 
hold all the cards; they are likely to enjoy a political playing field tilted in their favor and be in a prime position to maintain many elements of a status quo they previously benefitted from. Thus, through exogenously derived transitions, unresponsive authoritarian regimes will likely transform into unresponsive electoral democracies. I test this argument in cross-national analyses below, however, next, I offer a rough measurement of the exogeneity of a transition.

\section{Measuring the Exogeneity of Political Change}

Quantifying the level of influence various pressures have on any decision is problematic. As outsiders, what can seem to be most influential may not be. Because any outside observer lacks information on all the pressures and signals a specific decision-maker might have been exposed to, it is problematic to measure the degree of exogeneity of political decisions. As a proxy, one can rely on the information available about the time leading up to such a decision and on assumptions about different factors surrounding it.

As a first step to approximating the influence exogenous circumstances had on decisions to politically liberalize one might rely on the explicit statements available about pressure exerted for democratization. Some of the most detailed accounts of African politics can be found in the Africa Contemporary Record and the Africa Research Bulletin. The first provides summaries, and to some extent, analyses, of important events that occurred within a two year time span and the second gives reports of important events on a monthly basis. A review of the events reported in these publications in each country reveals evidence of international actors playing an important role in influencing each decision to adopt multiparty elections in the post Cold War era.

For example, in at least 15 cases, the country's main donor or financial institution directly tied its foreign assistance to the regime's commitment to democratic reforms by threatening to cut off access to foreign aid and/or actually doing so. In six cases, financial incentives were given or 
promised for democratization from the donors. For example, along with promising to pay for the elections, the French cooperation minister ensured that the "elections would restore links with the international financial community" (ARB 1993: 11030-11031) to the Central African Republic. With regard to at least four regimes’ decisions (Kenya, Mauritania, Lesotho, and Central African Republic) the reports mentioned some sort of "behind the scenes" talks between the country's leadership and donors, where the announcement of multiparty elections shortly followed. Another four cases of adopting multiparty elections were reported to be influenced by the leadership's attempt to appeal to Western donors, because they lost their patron, the Soviet Union, or access to other financing. Foreign influence was clear in 6 other cases, where, because the country had undergone a civil conflict, the UN set up the negotiations for, financed, and closely monitored the first multiparty elections. In six other cases the lack of foreign military involvement to help the regime during bouts of domestic instability was linked to the fact that it had not made significant democratic reforms.

In addition to these examples of specifically targeted donor pressure, there were also several exogenous events that, albeit were indiscriminate of which regimes they targeted, contributed to creating an environment of external pressure that influenced the decisions of many leaders. The fall of the Soviet Union, as has been discussed many times previously, was an external event that made its close allies second guess their domestic institutions. Additionally, main donors, like the US, France and Britain, made public statements about linking foreign aid to democratization on the continent in early 1990 (Crawford 2001: 4). While exogenous events like these did not necessarily target a regime in particular, they still had the effect of shaping regime incentives towards democratic reform. For example, in Tanzania's case, the leadership did not receive any direct threat of aid withdrawal (Vener 2000: 150). Instead, the decision to adopt multipartyism was heavily influenced by a belief among Tanzanian leadership that donors would revoke aid if they did not institutionalize multipartyism. This perception was largely formed in response to a series of general 
statements made by all of Tanzania's major donors that future of their development assistance policy would include democratic conditionalities (Vener 2000).

However, relying solely on this information to generate a measure of the influence of the importance of external pressure to democratize is problematic. Whether a regime was targeted with several different types of pressure tactics (i.e. foreign aid sanctioning, military withdrawal, loss of an important patron) is not necessarily a function of the importance of exogenous influence; and thus bars the validity of creating an additive measure or factor of these various donor tactics. In several cases, the longer a regime held out from reforming, the more tactics donors tried to use to pressure democratization. In those cases, the severity or number of the tactics used is more of a function of how long a regime avoided reform. Additionally, there were also the problems of inconsistency in reporting across cases. Smaller countries like Cape Verde and Sao Tome and Principe receive much less detailed reporting about all events.

Because there is evidence of foreign pressure in each of the post Cold War transitions, one might then turn to gauging the extent to which domestic pressure was important. If domestic pressure was present, one might assume that there was at least a mixture of both endogenous and exogenous pressures. However, the presence of domestic opposition to the ruling party or democratic movement does not necessarily mean that the decision to adopt democratic reforms was less exogenously based. ${ }^{31}$ Indeed, any measure of exogeneity of political change would have to be based on assumptions that underline the relative importance of either type of pressure, and not its mere existence.

To approximate the relative importance of various pressures in constructing an "exogeneity of political change" measure I focus on specific signals and rely on several assumptions. First, I use whether or not a multiparty election has been held as a signal of the country transitioning to

\footnotetext{
${ }^{31}$ In some cases popular pressure for democracy only started mounting only after clear signals from international donors were made.
} 
democracy. Second, I break up the sample of countries on the continent into those regimes that were impacted by external events that occurred during the post-Cold War period, and those that were not. As chapter two discussed, the incentives for regimes on the continent shifted quite dramatically post-Cold War. The end of the Cold War marked the beginning of an unprecedented period wherein most of Africa's important donors began to demand that regimes adopt democratic reforms and reward some of those that did. As stated earlier, reports during that time illustrate that these related external events likely impacted the decision to adopt multiparty politics in all countries that did so after the end of the Cold War. While these external events impacted the domestic politics of most countries on the continent, there were a handful of countries that have remained the same regime type they were prior the end of the Cold War. These regimes either had a record of holding consistent and regular multiparty elections prior to this unique period of foreign pressure or never held a multiparty election, even though, in some cases, they faced international pressure to do so. Thus countries that receive a zero on the exogeneity scale include those countries that did not show signs of capitulating to foreign pressures to hold multiparty elections, and those that were multiparty democracies prior to the end of the Cold War. I list these countries below by regime type:

\section{$\underline{\text { Countries given a } 0 \text { on the Exogeneity Scale }}$}

$\begin{array}{cc}\text { Democracies } & \text { Autocracies } \\ \text { Botswana } & \text { Eritrea } \\ \text { Mauritius } & \text { Somalia } \\ \text { Senegal } & \text { Swaziland } \\ & \text { Uganda } \\ & \text { Democratic Republic of Congo } \\ & \text { Angola }\end{array}$

The democracies on the list started their record of holding multiparty elections far before the end of the Cold War and have continued to hold them without any significant evidence of 
international pressure to do so. Mauritius and Botswana have had regular multiparty elections since independence, 1968 and 1966 respectively. Senegal switched from a one party socialist state to a multiparty system in 1978 largely to defuse domestic social, economic and political crisis (Fatton 1986: 72). For various reasons, the list of autocratic governments successfully avoided international pressure to adopt multiparty elections. For example, Eritrea only gained nationhood in 1993 and its subsequent conflict with Ethiopia buffered it against any significant external pressure to hold elections. Somalia has not had a functional government since 1991 and was autocratic prior to that. Swaziland outlawed oppositional parties in 1973. And, while the Democratic Republic of Congo had multiparty elections post Cold War, it did so in 2006, which is outside of the time frame I focus on. I limit my focus up to 2005 when categorizing countries because I am ultimately interested in examining the impact that exogenous democratization had on the change in social service delivery, during 1990 to 2005.

Finally, the cases of Angola and Uganda deserve some explanation. While Uganda's election in 2001 allowed other political candidates to compete, they were not allowed to do so under a recognized party affiliation. This case is somewhat ambiguous because political parties were banned from Uganda, but competition was allowed. For the reported models in table one I use the threshold for making significant political change as holding multiparty elections and thus have Uganda coded as a zero under the exogeneity of its political change. I do, however, summarize the results of several analyses wherein I examine if alternative coding in ambiguous cases produce different results; this is discussed further below.

Angola actually held multiparty elections in 1992, after a seventeen yearlong civil war. The elections were the product of an internationally brokered peace accord, which according to my rules of categorization (explained later), would give Angola a 2 on this scale. However, the multiparty system collapsed back into civil war only three months after the elections were held, and it would 
thus have little expected influence on social service delivery for the next 13 years. The country did not hold another set of multiparty elections until 2008, well after the period I focus on (1990 to 2005). This is similarly the case for Burundi, where civil war erupted after only four months of holding multiparty elections, however they held another election in 2005, within the time frame I focus on (this case is discussed later). While other countries experienced civil war and other interruptions in the holding of successive multiparty elections, like coups d'état, only in the case of Angola was another election not organized within the time frame of focus. Thus Angola's experience with electoral democracy across these 15 years seems to fit more in line with that of the other countries I categorize as staunchly authoritarian. Again in this case, I examine the effect of alternative coding below.

Finding evidence that all regimes were exposed to some sort of foreign pressure to democratically reform post Cold War informs the next assumption I make of the rest of the sample (i.e. the countries which held a first multiparty election during the 1990 to 2005 period): the decision to hold multiparty elections was at least partly rooted in exogenous circumstances. However, I divide the sample further by focusing on the outcome of the first, post Cold War, multiparty election. I assume that when the opposition party was able to unseat the ruling party in the first election that the domestic democratic movement held a significant amount of strength and power in pressuring that this change occurred. In other words, in these cases, I assume endogenous pressures were also significantly influential. Thus, countries that held multiparty elections post Cold War and the opposition was voted into power were given a 1 , or a middle position on the 0 to 2 exogeneity scale. I list these countries below with the year of their first, post-Cold War, multiparty election: 


\begin{tabular}{cc} 
Countries given a 1 on the Exogeneity Scale \\
\hline Benin & Election Year \\
Cape Verde & 1991 \\
Central African Republic & 1991 \\
Congo & 1992 \\
Madagascar & 1992 \\
Malawi & 1994 \\
Mali & 1992 \\
Niger & 1993 \\
Nigeria & 1999 \\
Sao Tome and Principe & 1991 \\
South Africa & 1994 \\
Zambia & 1991
\end{tabular}

In this category I assume that by itself, international pressure did not lead to democratization for these countries. Instead, democratization arose when the political conditionalities attached to foreign aid converged and interacted with domestic demands for political liberalization. For several of these countries, like in Benin, Central African Republic, Congo, Mali, Niger, Nigeria and Zambia, domestic democracy movements were born out of civil unrest targeted towards economic austerity measures, but swiftly turned towards demanding democracy (Gazibo 2005; ACR 1990/1992: B188; Clark 1994: 49; Shettima 1993; Rakner 1992). In Central African Republic, Congo and Zambia, among other places, domestic trade unions held significant leverage in pressuring incumbent governments to adopt democratic reforms (ACR 1990/1992: B188; Clark 1994: 49; Rakner 1992). In fact, in Zambia's case, the trade unions were one of the few organizations to have any autonomy from the almost all encompassing one-party state; it is this autonomy that gave citizens an alternative outlet to effectively organize their opposition to the regime (Rakner 1992). However these domestic groups gained important legitimacy, which translated into leverage in negotiations with the incumbent regime once their cause was supported by the international community. In Zambia's case, while the domestic element of its multiparty transition is often emphasized, it is also observed that 
the opposition to the regime only gained momentum and influence once it was supported by the international donor community (Rakner 2003: 21).

In several ways, donors and domestic democratic movements worked in conjunction for political reform. In some cases, donor pressure to politically reform intensified in reaction to large street demonstrations and/or when the regime would use repressive measures to attempt to silence the protest movement. This was the case in Malawi where donors suspended all foreign aid and conditioned future aid to whether political reforms would be taken after the Banda regime violently cracked down on an opposition rally which resulted in the deaths of 38 protestors (Brown 2004: 709). Similarly, in Madagascar, after the president Ratsiraka's body guard killed 100 and wounded many more peaceful democracy protestors, the French government suspended all military aid, advised the president to resign and offered him asylum in France (ASS 2004: 632).

The two sources of pressure worked in combination in other ways as well. In some cases the domestic democracy movements tried desperately to gain support from the international community so as to compel donors to use their leverage over the regime to push for reform. For example, in Malawi's case, some opponents to the Banda regime that were based in neighboring countries found it easier to lobby Western governments to withhold aid from the regime than to infiltrate the country and work internally for political change (ACR 1990-1992: b582). Additionally, donors became the pocketbook behind many transitions. For example, in several of these countries donors directly funded the efforts of domestic opposition groups (Sandbrook 1996). In Mali's case, opposition groups began received funding from France-Liberté, which was headed by Danielle Mitterrand, the wife of the French president (ACR 1990-1992: b82). Donors also played a role in providing the needed financial resources and electoral technology to stage the first multiparty national elections, as was the case in several countries on the list above (Sandbrook 1996: 69). 
The last group of countries includes those where I assume regimes held a multiparty election primarily due to changes in exogenous circumstances. These countries are given a 2 on the exogeneity scale because the regime in power held multiparty elections (regardless of the freeness or fairness of the election) during the 1990 to 2005 period but the ruling party was able to stay in power after the first election. I use the outcome of the first multiparty election as an indicator of the strength that domestic democracy groups had in influencing the impetus of the transition. While domestic pressure may have been present, if the opposition was not strong enough to unseat the ruling party at the first election, I assume that the domestic opposition was too weak to persuade the ruling party to concede the democratic reforms it ultimately did.

Additionally, countries are given a 2 on the exogeneity scale when they held their first multiparty election after a UN brokered peace deal, as these cases represent strong examples wherein the international community oversaw the democratic institutional building process (Paris 1997; Englebert and Tull 2008). Ethiopia and Comoros were also given a 2 because the unique circumstances that brought them to hold their first ever multiparty elections. Ethiopia's transition to multipartyism was similar to that of other countries who had adopted democratic institutions post conflict, but there the transition was largely overseen by only one major donor, the United States (Joseph 1998: 8; Engedayehu 1993: 30). ${ }^{32}$ Comoros's path to multipartyism was very different, however. After the President of Comoros, Ahmed Abdallah, was murdered in a coup in November of 1989, armed mercenaries under the control of Bob Denard attempted to gain control of the islands. In response, France sent a military force, which ultimately stopped Denard's attempts

\footnotetext{
32 Ethiopia's first ever multiparty election has held after a rebel movement, EPRDF, was victorious in taking over the country through a civil conflict. However, the rebel movement's victory was assisted by the U.S. government's approval of its military advances, which came with the condition that the movement promised to establish a democratic government, once in power (Joseph 1998:8). Once victorious, the United States worked in conjunction with the EPRDF by brokering the peace talks and aiding the new EPRDF government in setting up the democratic institutions it had expected of them (Engedayehu 1993: 30).
} 
(Nyang'oro 1996: 113). A strong French presence continued on the islands to oversee the installation of an acting president and the organization of the country's first multiparty elections. In fact, when riots from groups opposed to the then acting President, Mohamed Djohar, caused the closure of one of the polling stations during the first round of voting, French security forces stepped in to guarantee peace on the islands for a rerun of the poll (ACR 1990-1992: B276). I star the countries on the list that had their first election after a civil conflict or after a foreign power intervened militarily, like in the case of Comoros.

Zimbabwe and Gambia are also given a two on this scale, even though they both had multiparty elections prior to the end of the Cold War. Zimbabwe's case is interesting because it gained independence much later than the majority of African countries, in 1980 (the same year it held its first multiparty election). However donor influence was felt at independence, which came at the end of a civil war, wherein the international community successfully mediated talks between the warring parties (Gregory 1980). The mediation produced Zimbabwe's first constitution and, among other things, the constitution constrained the government from legislating for a one-party state system for its first decade (Sachikonye 1990: 98). In addition, once the decade long constraint on the constitution ran out, the ruling Mugabe regime started to campaign heavily for a change to the constitution to turn Zimbabwe into a one-party state (ACR 1990-1992: B719). However, the ruling party ruled out the possibility of legislating a one-party state; this decision was largely influenced by the need for the regime to secure foreign financing and the support of international donors (ACR 1990-1992: 719). Formally institutionalizing one-party rule was unnecessary to keep the country in the ruling party's control; ZANU-PF was officially re-elected in every poll during the 1990 to 2005 period. Thus the root of Zimbabwe's multipartyism is very similar to that of countries on this list where elections were produced after a post-civil war internationally brokered peace talk, and the exogenous influence on the continuation of multipartyism for Zimbabwe, as well as the ability of 
ZANU-PF to retain power despite elections, mirrors that of the rest of the countries who are given a 2 on this scale.

The Gambia too started its record of holding multiparty elections prior to the end of the Cold War, in 1965. However, as discussed previously, the country experienced a coup in 1994, which unseated Dawda Jawara, who, despite competing in multiparty elections, had been in power for 29 consecutive years. The coup installed Yahya Jammeh and after much international pressure, Jammeh held multiparty elections in 1996. Prior to the elections, Jammeh changed the constitution to give himself the electoral advantage, among others, of barring the previously deposed president from running as his competitor (Adejumobi 2000: 67). Jammeh won the 1996 election as well as the following two elections held in 2001 and 2006. The possible ambiguity of the Gambia's case comes from the fact that for four years (1990 to 1994) of the period of focus (1990 to 2005), the Gambia would have been considered a 0 on the exogeneity scale because of its history of holding multiparty elections, while for nine of the years (1996 to 2006) it would be considered a 2, because of the international pressure that Jammeh was under to transition to multipartyism and his subsequent ability to control the transition to produce his election in 1996. Ultimately because the Gambia's second experience with multipartyism lasted a majority of the time I focus on (nine of the fifteen years between 1990 and 2005), and this experience mirrored that of several other transitions that are considered a 2, I list the Gambia as a 2 on this scale.

Burundi's inclusion on this list also deserves further discussion. Similarly to Angola, in Burundi's case its first multiparty elections in 1993 were shortly followed by civil war. As in the case of Angola, I chose to not use this election because the multiparty system lasted for such a short period of time and was not followed closely by another multiparty election. ${ }^{33}$ Instead, I judge

\footnotetext{
33 However, if counted, although the 1993 election resulted in a change in power, it would be difficult to code it as a 1 , because the election was brought about primarily due to external pressure (Reyntjens 1993) and there was a large presence of international observers which may have guaranteed the freeness and fairness of the election (Kaiser 1999:
} 
Burundi based on its most recent election which occurred right at the end of the 1990 to 2005

period that I focus on. I test alterative coding for Burundi below and summarize their impact on the results.

\begin{tabular}{cccc}
\multicolumn{4}{c}{ Countries given a 2 on the Exogeneity Scale } \\
Election Year & \multicolumn{2}{c}{ Election Year } \\
Zimbabwe & 1980 & Guinea-Bissau & 1994 \\
Cote d'Ivoire & 1990 & Tanzania & 1995 \\
Burkina Faso & 1991 & Chad & 1996 \\
Cameroon & 1992 & The Gambia & 1996 \\
Ghana & 1992 & Sudan & $2000^{34}$ \\
Mauritania & 1992 & Namibia* & 1989 \\
Kenya & 1992 & Comoros* $^{*} 1990$ \\
Djibouti & 1993 & Mozambique* & 1994 \\
Equatorial Guinea & 1993 & Ethiopia* & 1995 \\
Gabon & 1993 & Sierra Leone* & 1996 \\
Guinea & 1993 & Liberia* & 1997 \\
Togo & 1993 & Rwanda* & 2003 \\
Seychelles & 1993 & Burundi* & $2005^{35}$
\end{tabular}

In the majority of the un-stared cases, the ruling parties were able to remain in power by controlling the speed and scope of democratic reforms. These regimes both exacerbated and exploited weaknesses in their opposition. In several of these countries the opposition was not allowed to effectively mobilize due to government intimidation and repression. In Zimbabwe, the government closed the Universities and briefly detained without trial student leaders of a protest

35). In other words, an oppositional win can also be partially attributed to the fact that exogenous actors somewhat constrained the ruling party.

${ }^{34}$ Like in Uganda, the Sudanese held elections in 1996 where opposition parties were banned, but other political competitors were allowed to run for office. As explained in the case of Uganda, for this measure, the threshold I use for marking significant political change is holding multiparty elections, so I list the year of Sudan's first multiparty election as 2000. However, the alternative, it occurring in 1996, would not change Sudan's coding on the exogeneity scale, because, as it was in 2000, the ruling party was re-elected in 1996.

${ }^{35}$ It occurred to me that countries that had multiparty elections so late into the period of focus (1990-2005) would likely not have a democracy effect due to the short period of time since the multiparty election occurred. To that end, I created a dummy variable for those countries that had elections from 2000 to 2005 and included it in unreported models. I found that there were no substantive changes in the results with that inclusion. Additionally, in reported models there is a measure for the age of the democracy which should control for this effect. 
movement and in Cameroon the police killed at least 6 protesters during an opposition rally (Bratton and van de Walle 1992: 423-424). In Equatorial Guinea's case, violently repressing calls for democracy was not only reserved for domestic sources of pressure; in early 1993, the ambassadors of Spain the US and EU received death threats from the regime due to their insistence on democracy (ACR 1992/1994). Additionally, the Equatorial Guinean regime also used more formal means to marginalize the opposition and the effects of a transition towards mulitpartyism. While the government adopted multipartyism through a new constitution in November 1991, in January of 1992, it also passed a law that barred the majority of Equatorial Guinean adults from legally joining an opposition party. The government outlawed people holding dual nationality from joining political parties; the country was under Spanish control until 1968, so anyone over the age of 24 at the time would have held dual nationality according to the new law (ARB: 1992: 1040b).

Regimes also used several tactics to divide oppositional movements and benefitted from the weakness of this fractionalization (Baker 1998: 122). In Kenya, for example, the Moi regime weakened the domestic democracy coalition by invoking ethnically divisive conflict through sponsoring armed units to attack specific ethnic communities (Roessler 2005: 215). The Moi regime was able to guard itself from any additional international backlash for these human rights abuses by distancing itself as the cause of the violence through portraying the clashes as a result of tribalism and ethnicity (Roessler 2005: 215). While manipulation of the playing field often secured a reelection for many of the ruling parties, in several countries on this list the ruling party held multiparty elections to later steal victory. In fact, Biya of Cameroon, Bongo of Gabon, Compaore of Burkina Faso, Conte of Guiena, Eyadema of Togo, Gouled of Djibouti, Moi of Kenya, Nguema of Equatorial Guinea, Rawlings of Ghana and Taya of Mauritania all succeeded in elections that were suspected of severe 'irregularities’ (Baker 1998:124).

At the same time that regimes were able to manipulate and repress the opposition in their 
efforts to call for reform, they faced substantial pressures from their donors to hold multiparty elections. Thus, for this category, I expect that multiparty elections were largely organized by ruling parties for the superficial purpose of appeasing the donor community, but done so carefully that they avoided introducing meaningful competition. It is my view that ruling parties sought to transform elections from an institution which made them vulnerable to competitors, to an event which would hopefully gain them international legitimacy, renewed financial links to donors, decrease external pressures for meaningful reform, and secure their dominance in power during this new "democratic" era. In fact, most political parties in this group maintained power throughout the 1990-2005 period of focus. For Djibouti, Cameroon, Gabon, Seychelles and Tanzania the surviving ruling party during this period was the same party in power since independence; as of 2005, the average number of years these parties had been in office was 38 .

However, in a handful of these countries, opposition parties have since won in subsequent multiparty elections (Côte d'Ivoire, Ghana, Guinea and Kenya for example). As mentioned earlier, this measure focuses on the outcome of the first election. This is particularly important for these cases. One of the hypotheses underlining my argument of the dampening effects of exogenous transitions on subsequent responsiveness is that exogenous transitions are more likely to result in institutions which allow for a ruling party to tilt the electoral playing field in its favor. Even when an opposition party does finally win in a subsequent election, theoretically, the new ruling party would equally benefit from these institutions for their own tenure in power. Such advantages work to reduce the chances of having fair competition and the incentive for politicians to capture votes by becoming more responsive to the needs of citizens. By only examining the outcome of the first election, I hope to approximate on the effects of the exogeneity of the transition and not subsequent political events.

Altogether, this scale makes no judgment on the extent of democratic reforms undertaken or 
the freeness or fairness of the first multiparty election. Togo, Mauritania, and Equatorial Guinea are certainly just a few cases that are given a 2 on this scale where one can easily argue that no substantive democratization actually took place. As mentioned earlier, one could also argue that in each of these cases the first "multiparty election" was stolen by the ruling party and other parties were not able to truly compete. When a regime calls for multiparty elections for the first time, but is able to repress all other parties or even outright steal the election, it begs the question: why are they holding them at all? Given the context of heightened international favor with multiparty democracy and the general dependence most of these regimes have on international patronage, it is likely, I argue, that the catalyst of elections in these settings was exogenous. While this scale does not approximate the extent of liberalization that has occurred in the country, the hypotheses I have put forth in this chapter posit that change in social service coverage is in some contexts a function of the extent to which a country democratized. Thus, as is explained below, I use this measure of exogeneity in analyses only when interacted with a measure of the extent of democratization, to test the merits of my arguments.

Two implicit assumptions that I made in constructing the measure should also be acknowledged. First, I assume that when an opposition candidate is elected in the first multiparty election, it signifies some degree of domestic oppositional strength. However, the decision to hold a multiparty election might be primarily exogenously pressured, but because of regime weakness (not oppositional strength), the ruling party could lose at the poles. This is a possible weakness in the measure and particularly relevant in the cases of Sao Tome and Principe and Cape Verde, where the opposition or domestic democratic movement was largely negligible. In both cases sectors of the elites organized opposition parties shortly before the elections were held. This organization may have been equally exogenously influenced, as it appears that they attempted to capitalize on the fact that the former ruling party would capitulate to foreign pressures to hold elections. This as well as 
other idiosyncrasies of the politics on these islands compelled me to run the same analyses that I report below with an additional control for these countries. In general, those unreported models return very similar results with regard to the impact of exogenously pressured democracy. The second assumption made is that when incumbents are re-elected, the domestic democratic movement is assumed to be weak, and thus, the democratization is judged to be primarily driven by exogenous influences. However, it is conceivably possible that an incumbent government was reelected into office by a majority of the people due to its popularity, and that the domestic democratic movement was powerful enough to persuade the government to hold elections. Thus the impetus could be domestically driven, while the result would have been that the regime remained in power. However, I am not aware of any cases in Africa that would fit this scenario.

These two possible weaknesses in the construction of the exogeneity scale speak to the ability of the measure to parse out meaningful differences between countries that should be considered completely exogenous and somewhat endogenous, (2 and 1 on the scale, respectively). Put differently, through the rubric generated based on the assumptions stated, I may be falsely identifying some countries as completely exogenously derived or not identifying some as completely exogenously derived, when I should be. While the case categorization should be debated, some descriptive statistics can highlight whether there is a meaningful difference between a 1 and 2 on the scale. A first step might be to look at the mean percent of seats held by an opposition party after the first multiparty legislative election across the 1 and 2 exogeneity scale categories. On average, countries scoring a 2 on the exogeneity scale should also have a lower percentage of legislative seats held by an opposition party, because opposition parties are likely to be fractionalized and relatively weak to the ruling party. Indeed this is the case; on average the main opposition party in coded 'mixed sourced' regimes captured $52.4 \%$ of the legislative seats in the first multiparty election, while in coded exogenous regimes, the main opposition party captured only $16 \%$ of the legislative seats. 
This difference is significant at the $1 \%$ percent error level.

Finally, while an effort was made to assign a score to each country, Lesotho was the only country not given a score on the above lists. This case was difficult to categorize because its election in 1993 proceeded after the rule of two military governments, the incumbent did not run in the election, and the election was followed by a coup, wherein the international community pressured the old regime and the coup leader to compromise into a power sharing agreement. As discussed in more detail below, there is arguably good reason to code Lesotho's case as a one or a two on this scale. While both are used in separate analyses which I report in table two, Lesotho remains the only missing case in table one. I turn next to discuss the estimation strategy of analyses which utilize this scale of exogeneity.

\section{Analyses of Exogenous Democratization and the Quality of Life}

To approximate what impact exogenous democratization has had on social service provisions and the quality of life in Africa, I run a series of cross-sectional OLS regressions with robust standard errors. The dependent variable in each case is the change in each quality of life indicator that was examined in chapter 1 from 1990 (or the closest year to 1990 that data was available) to 2005. Specifically, this includes the change in infant mortality, life expectancy, undernourishment, primary enrollment (net) and secondary enrollment rates (gross). This data comes from the World Bank's World Development Indicators.

The central hypotheses I am interested in testing are conditional. I expect that democratization should have a positive effect on the change in social services delivery when it is not exogenously derived, and no effect on the change in social services when democratization is more exogenous. To test these conditional hypotheses I include an interaction term between the variables where a moderating relationship is expected, in this case those are the extent of democratization and 
the previously discussed exogeneity scale. I use the change in Freedom House scores from 1990 to 2005, for a measure of democratization. ${ }^{36}$ The inclusion of this interaction variable allows me to examine what effect the change of democracy has had on the previously mentioned social service outcomes at various levels of exogeneity. I also control for whether a country was given a 0 on the exogeneity scale but were and have remained authoritarian, as I expect that these countries would not have the same regime based political incentive to improve social service delivery as democracies would.

In addition to approximating the effect of exogenous democratization, other plausibly important variables that would either help or hinder a government in the task of providing social services are controlled for. Specifically, the average GDP per capita, controlling for purchasing power parity, over 1990 to 2005 (in 2005 constant international dollars) is included to control for a nation's wealth or economic ability to provide services to its population. The average of GDP per capita over the entire period is used because using any single year might capture a particularly high or low point in the economy. I use a logged transformation of this data. I also control for the average rate of urbanization over the 1990-2005 period to account for the fact that an urbanized population might facilitate a government's job in delivering services. In urbanized countries a higher percentage of the population will be within one specific area where infrastructure is likely to be more developed than in the rural areas, where populations are more spread out and sometimes out of easy reach from paved roads. The average population of a country from 1990 to 2005 is also used as a control. Governments in more populous countries, it is assumed, have a more difficult and expensive task at providing services. Data for all three of these variables are all from the $W$ orld

\footnotetext{
${ }^{36}$ I used the average between the civil liberties and political rights scores. Also, the original Freedom House scores were changed to be more intuitive. Originally, they are coded so that the largest score (7) is the smallest level of freedom or democracy. I subtracted these scores by 8 to obtain a more intuitive scale where large numbers reflect a more free democracy. Therefore, the change in Freedom House scores are now intuitive so that positive change reflects a move away from undemocratic rule towards democratic rule.
} 
Bank's World Development indicators. ${ }^{37}$ Whether the country experienced a civil conflict in from 1985 to 2005 which resulted in at least 1,000 deaths, is included to account for the fact that civil conflicts are likely to have a negative effect on political stability, government capacity and infrastructure; all of which are likely to decrease a government's ability of providing social services. Data for this variable is from the PRIO civil conflict data. All of the above mentioned control variables were used in the analyses in chapter one and besides the inclusion of a control for whether or not the country experienced conflict, the rest of the variables were also used in Lake and Baum's (2001) analyses of social service provisions. ${ }^{38}$

Additionally, the age of democracy is also included in the analyses to account for Keefer's (2007) hypothesis that younger democracies perform worse than older democracies in providing social services. Younger democracies, it is argued, are more likely to suffer from a "low credibility" political environment, wherein political competitors are unable to "make credible promises to citizens about broad public policies" (Keefer 2007:805) due to the shorter period of time that politicians would have had to establish themselves as credible actors. In such an environment, the political incentives to provide public goods or campaign based on the provision of public goods are weak because most voters do not think of the promises of the incumbent or challenger as being credible, and instead politicians are incentivized to provide targeted goods to feed into established clientelist networks to secure political support is strong (Keefer 2007:806). To capture this concept, an attempt was made to mold Keefer's (2007) methodology of calculating the age of a country's democracy to the context of this research question. Keefer (2007) analyzed the age effect on a crosssection of dependent variables at one time frame; I examine its effect across a change in social

\footnotetext{
${ }^{37}$ Any missing observations for GDP per capita, ppp, were imputed using data from the IMF's World Economic Outlook Database.

${ }^{38}$ In Lake and Baum's (2001) study these variables were used in different forms. Instead of looking at the impact of democratization, they were analyzing the impact of the level of democracy. For this reason, they used similar variables but not as averages over the entire period, like I needed to do.
} 
service delivery. Ultimately, this measure was created by taking the number of consecutive years a country was either considered free or partly free on the Freedom House scale as of $2005 .{ }^{39}$

The above mentioned control variables have a plausible impact on the ability of all governments to provide high levels of social services. However, I also include a measure of ethnic fractionalization and a proxy for neopatrimonialism, which are two variables that have been hypothesized to impact the relationship between regime type and social services in the African context, specifically. Ethnic fractionalization is controlled for to account for argument that Africans are likely use their vote to reward a co-ethnic rather than to reward or punish a candidate for his/her performance on social service delivery; voting motivations of this nature reduce the incentive of politicians to provide broad based social services to secure future votes (van de Walle 2003: 313; Keefer and Khemani 2005). Unfortunately, there is not a cross national measure with sufficient country coverage of the extent to which different populations vote along ethnic lines for the time period I focus on. Alesina et al.'s (2003) ethnic fractionalization measure is used as a possible proxy of this concept. ${ }^{40}$ Along these lines, one would expect that greater ethnic fractionalization will decrease the changes in social services delivery.

As discussed in chapter one, citizens that live within a neopatrimonial political system may be more culturally passive with regard to the demands they make on the state, and instead view their own access to state resources as a function of their ability to draw upon personal ties (Bratton 1992: 93; van de Walle 2003). Such a political culture will likely decrease the proclivity for citizens to demand broad reaching social services and punish politicians at the polls for not providing such services. As there is no direct measure of the extent to which a country's political system is neopatrimonial, a common proxy for this concept, a measure of perceived corruption, is controlled

\footnotetext{
${ }^{39}$ The age of the democracy variable and the exogeneity scale are correlated at -0.22 .

${ }^{40}$ I did not use Posner's (2004) measure of Politically Relevant Ethnic Groups because of the missing observations in that data.
} 
for in the models instead. Specifically, I use an average of a country's score on the World Governance Indicator's measure of the control of corruption over the 1996 to 2005 time period. ${ }^{41}$ This measure was not calculated before 1996. Other corruption measures that do have data for years before 1996 were not used because they are missing data for many countries within my sample. I expect that countries with greater control over their corruption will have higher increases in social services over the 1990 to 2005 time period.

Finally, I also include the level of the respective social service/quality of life indicator in 1990 to capture any convergence trends. Summary statistics of each variable for these analyses appears in appendix II.

For every dependent variable I display two models. The first is a rough replication of similar models in the literature wherein democracy levels are usually found to be associated with social service levels. In the second model I include the exogeneity of the transition, interactive term, a dichotomous variable for whether the country was coded as a zero on the exogeneity scale, but was an authoritarian, and the age of the democracy. Table 1 displays the results of these tests.

\footnotetext{
${ }^{41} \mathrm{I}$ average this score over the years that are available within this time frame.
} 
Table 1: The Effect of Exogenous Democratization on the Change in Social Service Delivery

\begin{tabular}{|c|c|c|c|c|c|c|c|c|c|c|}
\hline & \multicolumn{2}{|c|}{ Infant Mortality } & \multicolumn{2}{|c|}{ Life Expectancy } & \multicolumn{2}{|c|}{ Undernourish } & \multicolumn{2}{|c|}{ Primary Enrollment } & \multicolumn{2}{|c|}{ Secondary Enrollment } \\
\hline & (1) & $(2)$ & (1) & $(2)$ & $(1)$ & $(2)$ & $(1)$ & (2) & (1) & (2) \\
\hline Infant Mortality, 1990 & $\begin{array}{c}-0.33 * * * \\
(0.11)\end{array}$ & $\begin{array}{c}-0.30 * * \\
(0.11)\end{array}$ & & & & & & & & \\
\hline Life Expectancy, 1990 & & & $\begin{array}{c}-0.54 * * \\
(0.22)\end{array}$ & $\begin{array}{c}-0.42 * * \\
(0.19)\end{array}$ & & & & & & \\
\hline Undernourish, 1992 & & & & & $\begin{array}{c}-0.57 * * * \\
(0.15)\end{array}$ & $\begin{array}{c}-0.61 * * * \\
(0.13)\end{array}$ & & & & \\
\hline Primary Enrollment, 1991 & & & & & & & $\begin{array}{c}-0.58 * * * \\
(0.12)\end{array}$ & $\begin{array}{c}-0.63 * * * \\
(0.13)\end{array}$ & & \\
\hline Secondary Enrollment, 1990 & & & & & & & & & $\begin{array}{c}-0.43 * * \\
(0.18)\end{array}$ & $\begin{array}{c}-0.38^{*} \\
(0.20)\end{array}$ \\
\hline Democ. Change, 1990 to 2005 & $\begin{array}{c}0.01 \\
(1.16)\end{array}$ & $\begin{array}{c}-7.20 * * \\
(3.43)\end{array}$ & $\begin{array}{c}0.59 \\
(0.69)\end{array}$ & $\begin{array}{l}3.23 * \\
(1.70)\end{array}$ & $\begin{array}{l}-1.18 \\
(1.37)\end{array}$ & $\begin{array}{c}-9.12 * * \\
(3.80)\end{array}$ & $\begin{array}{c}0.65 \\
(1.12)\end{array}$ & $\begin{array}{l}5.05^{*} \\
(2.69)\end{array}$ & $\begin{array}{c}0.88 \\
(1.86)\end{array}$ & $\begin{array}{l}8.39 * \\
(4.06)\end{array}$ \\
\hline GDP per capita, ln & $\begin{array}{l}7.11 * \\
(4.02)\end{array}$ & $\begin{array}{l}8.55^{*} \\
(4.67)\end{array}$ & $\begin{array}{l}-1.74 \\
(1.78)\end{array}$ & $\begin{array}{l}-1.76 \\
(1.94)\end{array}$ & $\begin{array}{l}-5.38^{*} \\
(3.00)\end{array}$ & $\begin{array}{l}-3.92 \\
(3.42)\end{array}$ & $\begin{array}{l}-1.67 \\
(3.93)\end{array}$ & $\begin{array}{c}0.38 \\
(4.50)\end{array}$ & $\begin{array}{c}6.78 \\
(6.18)\end{array}$ & $\begin{array}{c}7.25 \\
(6.50)\end{array}$ \\
\hline Urbanization & $\begin{array}{c}-0.31 * \\
(0.18)\end{array}$ & $\begin{array}{c}-0.37 * \\
(0.20)\end{array}$ & $\begin{array}{l}0.11 * \\
(0.06)\end{array}$ & $\begin{array}{c}0.08 \\
(0.06)\end{array}$ & $\begin{array}{c}0.00 \\
(0.17)\end{array}$ & $\begin{array}{l}-0.08 \\
(0.17)\end{array}$ & $\begin{array}{l}-0.21 \\
(0.17)\end{array}$ & $\begin{array}{c}-0.33 * \\
(0.19)\end{array}$ & $\begin{array}{c}0.12 \\
(0.18)\end{array}$ & $\begin{array}{c}0.04 \\
(0.17)\end{array}$ \\
\hline Civil Conflict & $\begin{array}{l}-0.84 \\
(4.84)\end{array}$ & $\begin{array}{l}-1.08 \\
(5.28)\end{array}$ & $\begin{array}{c}0.40 \\
(2.38)\end{array}$ & $\begin{array}{c}0.93 \\
(2.16)\end{array}$ & $\begin{array}{l}-2.18 \\
(3.41)\end{array}$ & $\begin{array}{l}-1.15 \\
(3.83)\end{array}$ & $\begin{array}{c}-17.65 * * * \\
(4.19)\end{array}$ & $\begin{array}{c}-16.58 * * * \\
(5.03)\end{array}$ & $\begin{array}{l}-3.07 \\
(4.27)\end{array}$ & $\begin{array}{l}-2.92 \\
(4.31)\end{array}$ \\
\hline Population & $\begin{array}{l}-0.00 \\
(0.00)\end{array}$ & $\begin{array}{l}-0.00 \\
(0.00)\end{array}$ & $\begin{array}{l}-0.00 \\
(0.00)\end{array}$ & $\begin{array}{l}-0.00 \\
(0.00)\end{array}$ & $\begin{array}{l}-0.00 \\
(0.00)\end{array}$ & $\begin{array}{l}-0.00 \\
(0.00)\end{array}$ & $\begin{array}{l}0.00 * \\
(0.00)\end{array}$ & $\begin{array}{c}0.00 * * \\
(0.00)\end{array}$ & $\begin{array}{l}0.00 * \\
(0.00)\end{array}$ & $\begin{array}{l}0.00 * \\
(0.00)\end{array}$ \\
\hline Ethnic Fractionalization & $\begin{array}{c}15.41 \\
(12.74)\end{array}$ & $\begin{array}{l}23.11 * \\
(12.53)\end{array}$ & $\begin{array}{l}-1.47 \\
(6.14)\end{array}$ & $\begin{array}{l}-4.93 \\
(5.21)\end{array}$ & $\begin{array}{c}-18.31 * * \\
(8.87)\end{array}$ & $\begin{array}{c}-15.60 \\
(9.34)\end{array}$ & $\begin{array}{c}2.85 \\
(8.21)\end{array}$ & $\begin{array}{c}0.39 \\
(7.75)\end{array}$ & $\begin{array}{l}-7.87 \\
(6.54)\end{array}$ & $\begin{array}{c}-12.38 \\
(9.14)\end{array}$ \\
\hline Control of Corruption & $\begin{array}{c}-16.44 * * * \\
(4.22)\end{array}$ & $\begin{array}{c}-14.03 * * \\
(5.33)\end{array}$ & $\begin{array}{c}2.67 \\
(2.08)\end{array}$ & $\begin{array}{c}3.34 \\
(2.61)\end{array}$ & $\begin{array}{l}-8.79 \\
(5.68)\end{array}$ & $\begin{array}{c}-12.54 * * \\
(5.48)\end{array}$ & $\begin{array}{l}5.77 * \\
(2.95)\end{array}$ & $\begin{array}{c}4.23 \\
(4.36)\end{array}$ & $\begin{array}{c}9.10 \\
(5.61)\end{array}$ & $\begin{array}{l}10.16 \\
(6.47)\end{array}$ \\
\hline Exog. & & $\begin{array}{l}-1.50 \\
(3.19)\end{array}$ & & $\begin{array}{l}1.99 \\
(2.13)\end{array}$ & & $\begin{array}{c}-11.43 * * * \\
(3.58)\end{array}$ & & $\begin{array}{c}4.28 \\
(4.30)\end{array}$ & & $\begin{array}{c}5.02 \\
(5.68)\end{array}$ \\
\hline Exog. $*$ Democ. Change & & $\begin{array}{l}3.95 * \\
(2.18)\end{array}$ & & $\begin{array}{c}-1.57+ \\
(1.04)\end{array}$ & & $\begin{array}{c}4.82 * * \\
(2.11)\end{array}$ & & $\begin{array}{c}-2.91+ \\
(2.01)\end{array}$ & & $\begin{array}{c}-4.99 * \\
(2.53)\end{array}$ \\
\hline Authoritarian & & $\begin{array}{l}-8.11 \\
(9.19)\end{array}$ & & $\begin{array}{l}-2.91 \\
(5.31)\end{array}$ & & $\begin{array}{c}-22.91 * * \\
(8.67)\end{array}$ & & $\begin{array}{c}-4.66 \\
(11.11)\end{array}$ & & $\begin{array}{c}-0.75 \\
(12.73)\end{array}$ \\
\hline Age of Democracy & & $\begin{array}{l}-0.11 \\
(0.29)\end{array}$ & & $\begin{array}{l}-0.16 \\
(0.20)\end{array}$ & & $\begin{array}{l}-0.11 \\
(0.29)\end{array}$ & & $\begin{array}{c}0.30 \\
(0.31)\end{array}$ & & $\begin{array}{c}0.01 \\
(0.50)\end{array}$ \\
\hline Observations & 46 & 44 & 46 & 44 & 42 & 41 & 39 & 37 & 34 & 33 \\
\hline R-squared & 0.45 & 0.52 & 0.34 & 0.46 & 0.41 & 0.64 & 0.72 & 0.76 & 0.50 & 0.61 \\
\hline F test & 4.28 & 3.95 & 2.36 & 3.42 & 4.46 & 4.01 & 13.87 & 8.11 & 3.86 & 4.62 \\
\hline Prob $>F$ & 0.00 & 0.00 & 0.04 & 0.00 & 0.00 & 0.00 & 0.00 & 0.00 & 0.00 & 0.00 \\
\hline
\end{tabular}


The first models for each dependent variable, which estimate the effect of democratization on the change in these various social service outcomes, without accounting for the exogeneity of the transition towards democracy, confirm the findings I review in chapter 1; when controlling for only "conventional" variables, democratization is not positively and significantly related to the change in social services in Africa. This chapter has outlined an argument to suggest that democratization's null effect in these models is due to the fact that conventional models do not account for the dampening effect that exogenously derived democratization has on leadership's incentives to provide broad reaching social services. The results in table one provides support for this notion. Once exogenous democratization is controlled for (in the second models), democratic change becomes positively and significantly related to the change in social services across all models. This signifies that a conventional model of the effect of democratization on social services in Africa fails to capture the positive effect of democratization because it omits controlling for the type of political change the country went through.

The nature of my core hypothesis is that democratization's effect is conditional upon the extent to which the transition was exogenously derived. As such, I expect that the interaction term between democratic change and exogeneity will have a significant $\mathrm{p}$ value, to indicate that democracy's effect is in fact conditional on the exogeneity of the transition. Consistent with this expectation, across all models, the interaction term between exogenous political change and democratic change is significant, albeit in some cases only at the 0.10 error level in a one-tailed test. ${ }^{42}$ However, it is not enough to establish the significance of this relationship to support the core hypotheses that are proposed. Democratization, it has been argued, should be associated with positive changes in social services when the transition is less exogenously derived and not associated

\footnotetext{
42 For each analysis where the interaction between change in democracy and the exogeneity scale is included, I test for whether the inclusion of the interaction is significant with an f-test. For all models the prob $>\mathrm{F}$ is below 0.20 , and for Infant Mortality, Undernourishment and Secondary Enrollment it is below 0.10 .
} 
with increases in social services when democratic reforms were taken primarily for exogenous audiences. To establish whether the effects of the interaction term are in the expected direction, I calculate the slope of democratic change at different levels of exogeneity. Figure 1 graphically displays those results. 
Figure 1: The Slope of Democracy at Various levels of Exogeneity
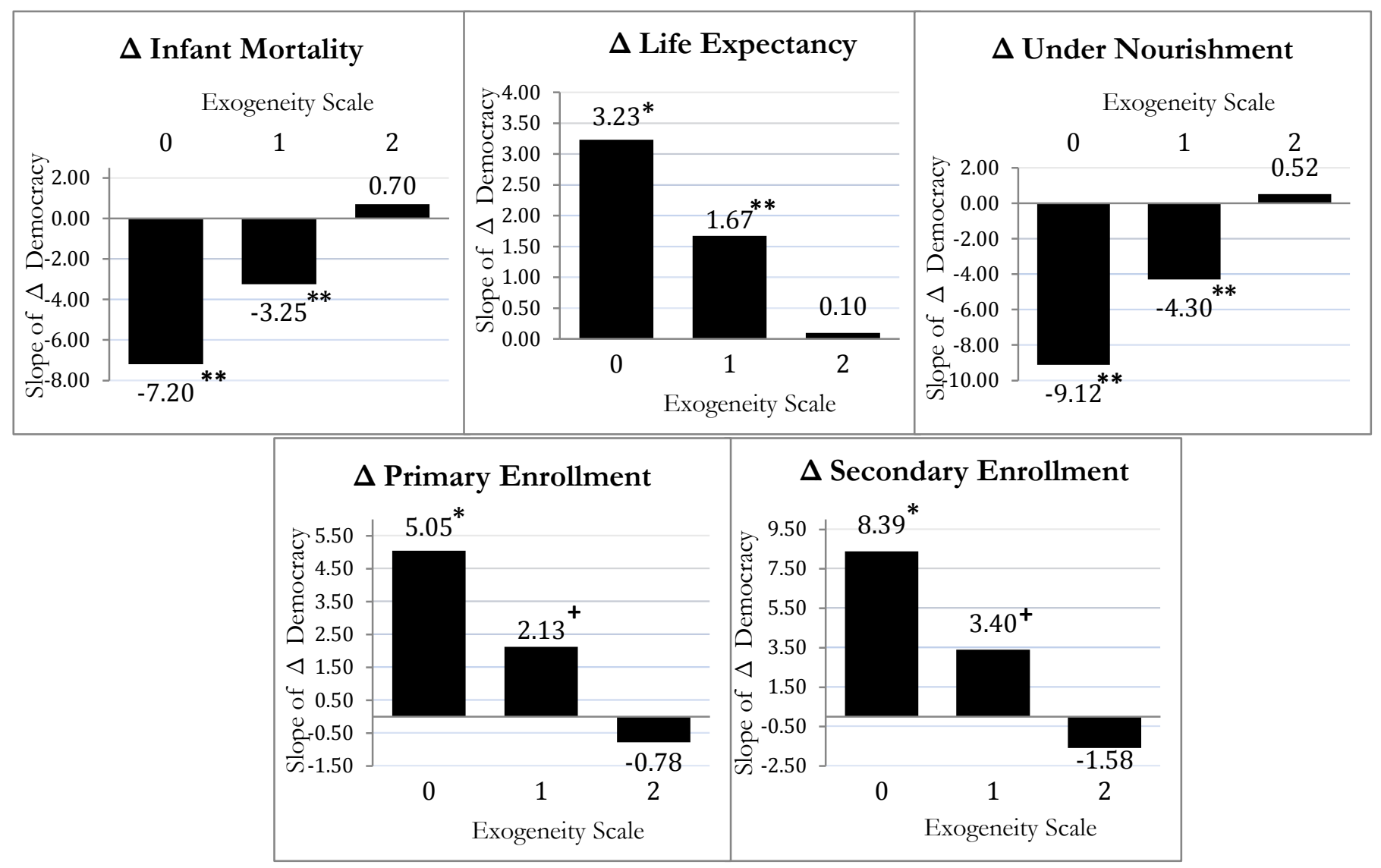

${ }^{* * *} \mathrm{p}<0.01$ (two-tailed), ${ }^{* *} \mathrm{p}<0.05$ (two-tailed), ${ }^{*} \mathrm{p}<0.10$ (two-tailed), $+\mathrm{p}<0.10$ (one-tailed) 
The above figure illustrates the effect of change in democracy on the change in social service outcomes, at different levels of exogeneity. Consistent with my hypothesis, in each model, I find that at a zero level of exogeneity (most endogenous), a change in democracy has a positive and significant impact on the change in social services. Specifically, endogenously derived democracy positively impacts changes in primary and secondary enrollment rates, as well as life expectancy. And, as expected, endogenously derived democracy is associated with decreases in the percentage of people that are undernourished and a country's infant mortality rates. These trends lend support to the argument that when democratization is endogenously derived it will have the intended effects that conventional models assume it to have: it increases the incentives of leadership to provide higher levels of social services. It was also expected, however, that when democracy is exogenously derived, leadership will be less likely to be incentivized to provide higher levels of social services. The results are again consistent with this expectation. Specifically, across all models, the effect of democratization decreases dramatically when a country is coded as a one, as compared to when countries are coded as a zero on the exogeneity scale. Further, I find that in every model, the change of democracy ceases to have a significant effect on the change in social services at the most exogenous level of political change. Finally, the inclusion of the variables related to capturing exogenous democratization improves model fit, for every dependent variable; as one can see by comparing the r-squared in each model one to their respective model two. Thus, the results reported in table one and figure one support the hypotheses put forward in this chapter; democratization is positively related to changes in the quality of life where domestic pressure was essential to reach democratic reforms, less so when that domestic pressure was also combined with significant international pressure and should not be associated with social service delivery performance when exogenous pressures were most important to democratic reforms.

Aside from the effects related to the inclusion of exogenous democracy, only the 
convergence terms, which are, as expected, negatively and significantly related to change in the quality of life indicators, have consistently significant effects across all indicators.

\section{Robustness Checks with Alternative Coding of Ambiguous Cases}

Especially given the fact the dependent variables capture a variety of social service and quality of life indicators, the consistency of the findings presented in table 1 and figure 1 are particularly striking. I will now examine whether this consistency is vulnerable to recoding the exogeneity score of ambiguous cases. As a reminder, the cases that I thought were somewhat ambiguous and are thus recoded in the below analyses are Angola, Uganda, Burundi and Lesotho. In previous analyses I code Angola as a zero because it seemed to echo more closely the experience of other staunchly authoritarian regimes. Although Angola held multiparty elections in 1992, civil war broke out only three months later and multiparty elections were not again held until 2008. Thus, for Angola multipartyism did not take root with any degree of regularity and instead the country was embroiled in civil war for the vast majority of the time period that I focus on. I reasoned that multipartyism could not have much of an effect because its lifespan existed for only a few months. If we were to count the 1992 election, however, Angola would switch its coding from a zero to a two on the exogeneity scale because the election occurred after an internationally brokered peace accord.

Uganda's case is similar to that of Sudan; both countries held elections where politicians were allowed to compete for office but opposition political parties were banned. In the analyses reported in table 1 I did not count these elections as each country's first multiparty election because I used the threshold of allowing multiple parties to compete in coding each country's "transition." However, one could argue that elections that allow competition but not recognized parties are still a first step towards democratization. If the elections where opposition parties were banned are counted as each country's transition election, Sudan's coding would not change; it was a two on the 
scale in the previous analyses and would remain so because both elections occurred within the timeframe I focus on and both resulted in the ruling party staying in office. However, Uganda's coding would change from a zero to a two. Uganda was coded a zero on the exogeneity scale because its first election wherein multiple parties were recognized occurred after the time period I focus on, in 2006, so it was coded as if it did not have an election at all. However its first competitive election occurred in 2001, and the ruling party was re-elected through that election.

Burundi's case is somewhat similar to that of Angola; its first multiparty election, in 1993, was shortly followed by civil war. As in the case of Angola, I chose to not recognize this election as the transition election in the analyses above because the multiparty system lasted for such a short period of time and was not followed closely by another multiparty election. Additionally, others have written about the importance of international pressure and international observers in the 1993 election (Reyntjens 1993; Ndikumana 1998: 36; Uvin 1999: 261), which further supported it being considered exogenously derived. However, the 1993 election resulted in a change of power, so I retest this case by recoding Burundi from a two to a one on the exogeneity scale.

Finally, Lesotho was the only country that was not given a score on the exogeneity scale, and is thus a missing observation in the analyses reported on table one. This case was particularly difficult to categorize because its election in 1993 proceeded after the rule of two military governments, the incumbent did not run in the election, and the election was shortly followed by a coup, wherein the international community pressured the old regime and the coup leader to compromise into a power sharing agreement. On the one hand, Lesotho's election in 1993 should be considered as a one on the exogeneity scale because it did result in a sort of change in power. While the ruling military coup leader was not competing, the military leader which led the previous coup was, and was overwhelmingly rejected at the polls (Southall 1994). However, the events leading up to the 1993 election and post-election seem to make a stronger case for the exogeneity of 
Lesotho's democracy. Prior to the election, donors targeted the military junta with significant aid withdrawal and the closure of aid programs (Matlosa 1999:25). Additionally, a little more than a year after the 1993 election was held, King Letsie III staged a coup and in response Lesotho's major donors suspended all aid to the country (Matlosa 1999:27). Due to this pressure, the King was forced to negotiate at internationally brokered negotiations and settled on a pseudo-power sharing deal with the old ruling party (Matlosa 1999: 27). In many ways, Lesotho’s continuation of mulitpartyism seems to be a function of the international community's leverage over the regime. The events surrounding Lesotho's 1993 election made it difficult to choose one categorization over another for Lesotho. I rerun the regressions with this case as coded a one and a two below.

In testing the effects of coding cases with different scores for exogeneity, I re-ran the "second models" of table one for every case of alternative coding. I found support for the hypotheses discussed for three indicators. First, I found that when exogenous democratization (the interaction term) is included, the change in democracy is significantly and positively related to the change in social services. This indicated that the "conventional" models (model ones of table one) failed to capture the positive impact of democratization on social services because they omitted a variable which approximated the type of transition the country went through. Second, evidence that there is the expected moderating relationship between exogenous change and democratization is expressed through a significant $\mathrm{p}$ value of the interaction coefficient. Third, I found support for the hypotheses that when democracy is endogenously derived it will positively impact social services and when it is exogenously derived it will not be associated with changes in social services through estimating the slope of democratic change at various levels of exogeneity, as was displayed graphically in figure one. Specifically, I found that the slope of democratic change at a zero level of exogeneity is significant and positive, less so at a one on the scale of exogeneity and not at all at a zero level of exogeneity. Thus, in table two, I summarize these three types of results, which are most 
important to testing my hypotheses for each case of alternative coding. 
Table 2: Summary of Results from Alternative Coding Analyses

\begin{tabular}{|c|c|c|c|c|c|c|c|c|c|c|c|}
\hline \multirow{6}{*}{$\begin{array}{l}\text { Angola } \\
2 \text { for } \\
\text { Exog }\end{array}$} & \multirow[b]{2}{*}{ Democ. $\Delta, 1990$ to 2005} & \multicolumn{2}{|c|}{$\begin{array}{c}\text { Change in Infant } \\
\text { Mortality }\end{array}$} & \multicolumn{2}{|c|}{$\begin{array}{l}\text { Change in Life } \\
\text { Expectancy }\end{array}$} & \multicolumn{2}{|c|}{$\begin{array}{c}\text { Change in } \\
\text { Undernourish }\end{array}$} & \multicolumn{2}{|c|}{$\begin{array}{c}\text { Primary } \\
\text { Enrollment }\end{array}$} & \multicolumn{2}{|c|}{$\begin{array}{l}\text { Secondary } \\
\text { Enrollment }\end{array}$} \\
\hline & & $-6.45^{*}$ & $(3.66)$ & $-3.00 *$ & $(1.79)$ & $-10.38 * * *$ & $(4.02)$ & $5.05 *$ & $(2.69)$ & $8.39 *$ & $(0.20)$ \\
\hline & Exog. * Democ. Change & $3.48+$ & $(2.21)$ & $-1.46+$ & $(2.14)$ & $5.46 * *$ & $(2.19)$ & $-2.91+$ & $(2.01)$ & $-4.99 *$ & $(2.53)$ \\
\hline & Slope of Democ. at 0 Exog. & $-6.45 *$ & $(3.66)$ & $3.00 *$ & $(1.79)$ & $-10.38 * * *$ & $(4.02)$ & $5.05 *$ & $(2.69)$ & $8.39 *$ & $(0.20)$ \\
\hline & Slope of Democ. at 1 Exog. & $-2.97 *$ & $(1.75)$ & $1.54 *$ & $(0.84)$ & $-4.93 * *$ & $(2.10)$ & $2.13+$ & $(1.35)$ & $3.40+$ & $(2.12)$ \\
\hline & Slope of Democ. at 2 Exog. & 0.50 & $(1.57)$ & 0.07 & $(0.69)$ & 0.53 & $(1.50)$ & -0.78 & $(2.11)$ & -1.58 & $(2.32$ \\
\hline \multirow{5}{*}{$\begin{array}{l}\text { Uganda } \\
2 \text { for } \\
\text { Exog }\end{array}$} & Democ. $\Delta, 1990$ to 2005 & $-6.80 *$ & $(3.46)$ & $3.07 *$ & $(1.68)$ & $-8.86 * *$ & $(3.80)$ & $7.22 * *$ & $(3.02)$ & $7.34 *$ & $(4.12)$ \\
\hline & Exog. * Democ. Change & $3.82 *$ & $(2.20)$ & $-1.46+$ & $(1.04)$ & $4.72 * *$ & $(2.12)$ & $-4.00 *$ & $(2.12)$ & $-4.44 *$ & $(2.60)$ \\
\hline & Slope of Democ. at 0 Exog. & $-6.80 *$ & $(3.46)$ & $3.07 *$ & $(1.68)$ & $-8.86 * *$ & $(3.80)$ & $7.22 * *$ & $(3.02)$ & $7.34 *$ & $(4.12)$ \\
\hline & Slope of Democ. at 1 Exog. & $-2.98 *$ & $(1.59)$ & $1.61 * *$ & $(0.77)$ & $-4.14 * *$ & (1.98) & $3.22 * *$ & $(1.52)$ & $2.90+$ & $(2.11)$ \\
\hline & Slope of Democ. at 2 Exog. & 0.84 & $(1.66)$ & 0.15 & $(0.71)$ & 0.58 & $(1.55)$ & -0.79 & $(2.11)$ & -1.53 & $(2.32)$ \\
\hline \multirow{5}{*}{$\begin{array}{c}\text { Burundi } \\
1 \text { for } \\
\text { Exog }\end{array}$} & Democ. $\Delta, 1990$ to 2005 & $-5.84 *$ & $(3.41)$ & $2.87+$ & $(1.72)$ & $-8.12 * *$ & $(3.76)$ & $4.66+$ & $(2.77)$ & $8.84 * *$ & $(4.02)$ \\
\hline & Exog. $*$ Democ. Change & $3.08+$ & $(2.16)$ & -1.33 & $(1.05)$ & $4.17 *$ & $(2.09)$ & -2.62 & $(2.10)$ & $-5.32 * *$ & $(2.55)$ \\
\hline & Slope of Democ. at 0 Exog. & $-5.84 *$ & $(3.41)$ & $2.87+$ & $(1.72)$ & $-8.12 * *$ & $(3.76)$ & $4.66+$ & $(2.77)$ & $8.84 * *$ & $(4.02)$ \\
\hline & Slope of Democ. at 1 Exog. & $-2.75 *$ & $(1.59)$ & $1.54 *$ & $(0.79)$ & $-3.95 *$ & $(1.96)$ & $2.04+$ & $(1.34)$ & $3.53 *$ & $(2.05)$ \\
\hline & Slope of Democ. at 2 Exog. & 0.33 & $(1.67)$ & 0.21 & $(0.70)$ & 0.23 & $(1.51)$ & -0.58 & $(2.17)$ & -1.79 & $(2.31)$ \\
\hline \multirow{5}{*}{$\begin{array}{l}\text { Lesotho } \\
2 \text { for } \\
\text { Exog }\end{array}$} & Democ. $\Delta, 1990$ to 2005 & $-7.26 * *$ & $(3.37)$ & $3.40 * *$ & $(1.63)$ & $-9.09 * *$ & $(3.79)$ & $4.98 *$ & $(2.69)$ & $8.37 * *$ & $(4.01)$ \\
\hline & Exog. * Democ. Change & $4.09 *$ & $(2.16)$ & $-1.80 *$ & $(1.04)$ & $4.60 * *$ & $(2.12)$ & $-2.82+$ & $(1.95)$ & $-4.96 *$ & $(2.49)$ \\
\hline & Slope of Democ. at 0 Exog. & $-7.26 * *$ & $(3.37)$ & $3.40 * *$ & $(1.63)$ & $-9.09 * *$ & $(3.79)$ & $4.98 *$ & $(2.69)$ & $8.37 * *$ & $(4.01)$ \\
\hline & Slope of Democ. at 1 Exog. & $-3.18 * *$ & $(1.54)$ & $1.60 * *$ & $(0.74)$ & $-4.49 * *$ & $(1.95)$ & $2.16+$ & $(1.34)$ & $3.41+$ & $(2.10)$ \\
\hline & Slope of Democ. at 2 Exog. & 0.91 & 1.65 & -0.20 & $(0.77)$ & 0.11 & $(1.48)$ & -0.66 & $(1.99)$ & -1.54 & $(2.26)$ \\
\hline \multirow{5}{*}{$\begin{array}{l}\text { Lesotho } \\
1 \text { for } \\
\text { Exog }\end{array}$} & Democ. $\Delta, 1990$ to 2005 & $-5.67 *$ & $(3.27)$ & 1.83 & $(2.07)$ & $-10.25 * * *$ & $(3.53)$ & $5.04 *$ & $(2.56)$ & $7.81 *$ & $(3.91)$ \\
\hline & Exog. $*$ Democ. Change & $3.12+$ & $(2.10)$ & -0.78 & $(1.21)$ & $5.38 * *$ & $(1.99)$ & $-2.91+$ & $(1.93)$ & $-4.64 *$ & $(2.41)$ \\
\hline & Slope of Democ. at 0 Exog. & $-5.67 *$ & $(3.27)$ & 1.83 & $(2.07)$ & $-10.25 * * *$ & (3.53) & $5.04 *$ & $(2.56)$ & $7.81 *$ & $(3.91)$ \\
\hline & Slope of Democ. at 1 Exog. & $-2.55 *$ & $(1.52)$ & 1.05 & $(0.95)$ & $-4.87 * *$ & $(1.85)$ & $2.13+$ & $(1.31)$ & $3.17+$ & $(2.10)$ \\
\hline & Slope of Democ. at 2 Exog. & 0.57 & $(1.65)$ & 0.28 & $(0.70)$ & 0.51 & $(1.54)$ & -0.77 & $(2.09)$ & -1.48 & $(2.28)$ \\
\hline
\end{tabular}

Coefficient is on the left and robust standard error is on the right in parentheses.

$* * * \mathrm{p}<0.01$ (two-tailed), $* * \mathrm{p}<0.05$ (two-tailed), $* \mathrm{p}<0.10$ (two-tailed) $+\mathrm{p}<0.10$ (one-tailed) 
The results in table two are generally consistent with those of table one and figure one; however there are some cases where recoding impacts the consistency of support for the hypotheses across all dependent variables. Analyses where Angola is recoded to a 2, Uganda to a 2, and Lesotho to a 2 on the exogeneity scale all produce results consistent to that of table one and figure one. Specifically, the change in democracy is significantly and positively related to the change in social service outcomes when exogenous democratization is controlled for across all dependent variables. The interaction term between exogeneity and democratization is significant to at least the 0.10 error level on a one tailed test (and in the case of Uganda and Lesotho's recoding the $\mathrm{p}$ value of this relationship is generally more significant than it was in the original analyses displayed in table two). Additionally, the slope of democracy is significantly and positively related to all social service outcomes when calculated at a zero level of exogeneity, the slope of democracy is estimated to be around half of its zero level of exogeneity value at a one level of exogeneity and it is insignificant at a two on the exogeneity scale.

Additionally, the consistency of these results hold true for a majority of dependent variables in the other cases of alternative coding. When Lesotho is coded as a one, the results from the regression estimating the change in life expectancy is only set which does not support the hypotheses I discussed earlier. In this model, the change in democracy is not significantly related to change in social services once exogenous democratization is controlled for and the interaction term is not significant at all. In the analyses where Burundi is recoded as a one on the exogeneity scale, the significance of the change in democracy coefficient falls in the life expectancy and primary enrolment models from a two tailed 0.10 error level to a one tailed 0.10 error level. Additionally, in these models, the interaction between exogeneity and democratization is not significant. However, in both of these analyses, the slope of democracy, when estimated at a zero level and a middle point of exogeneity (a one), is still positively and significantly (to at least the 0.10 error level in a one tailed 
test), related to the change in social services. Thus, in each case of alternative coding, I still find that in a majority of analyses, the exogeneity of democratization can help to explain why democratic change is not "conventionally" associated with changes in social service delivery. Additionally, the reviewed analyses provide considerable support for the hypotheses that democratization is least likely to result in responsive governance when it is most exogenously derived, and should be associated with increases in the quality of life when it is rooted in endogenous sources.

\section{Conclusion}

The impacts of democratization on the quality of life in Africa should be understood within the context of the variations in its origins. When derived endogenously, democratization in Africa is associated with increases in the quality of life and standard of living. However, when the pressure to adopt democratic reforms comes primarily from foreign sources, those reforms, however substantial they may be in other respects, do little to bring Africans responsive governments. In this chapter I have argued that these trends can be understood in light of the likely implications of exogenously derived democratization. Specifically, in exogenously derived democracies, ruling elites are beholden mainly to the needs of donors. However, donors are, for many reasons, unlikely to use their leverage over regimes to return higher levels of responsiveness. Additionally, exogeneously derived democracies are likely to result in an imbalance in the political playing field at home, i.e. it is unlikely that an opposition party can act as an effective domestic check on the power of ruling elites. These two characteristics reduce the electoral incentive that supposedly ties democratic leaders to the needs of their constituents.

In the next chapter I turn to a more detailed look at the mechanisms that underline the relationship between democracy and social service delivery. Specifically, I report the findings from in-country fieldwork in Zambia, a country where the transition to multipartyism was heavily 
influenced by both domestic and international sources of pressure. I examine, on the ground, how citizens in Zambia demand social services and how politicians respond to these demands. Also, I trace the evolution of "responsive" policies in Zambia and find that while strides were initially made to institutionalize a level of local government responsiveness post-transition, later erosions in the democratic experiment undermined the effectiveness that these institutions ultimately ever had in increasing the quality of life for Zambians. 


\section{Chapter Four: Multiparty Politics and Social Service Delivery in a Hybrid Regime, Zambia}

While a move toward competitive-multiparty politics is often hypothesized to have a positive effect on social services, its impact in Africa has proven to be contextual. Chapter 3 demonstrated that when exogenously rooted, democratization will likely not have an impact on social service delivery. Chapter three's analyses compare well with the larger literature on a theoretically positive link that democracy has with social service delivery as it too investigates this relationship crossnationally and systematically (Rudra and Haggard 2005, Bueno de Mesquita et al. 2003; Deacon 2003, 2009; Brown 1999; Frey and Al-Roumi 1999; Shandra et al. 2004; Baum and Lake 2003; Lake and Baum 2001; Ross 2006). While cross-national analyses highlight whether or not relationships hypothesized hold, they do little to explore exactly why they hold, on the ground. Thus, we are still left with important questions, including: How do citizens of new democracies actually demand services? How do their politicians respond to these demands? How does the exogeneity of a transition impact an elected official's incentives to act in a responsive nature? In this chapter I investigate these questions by offering a case study of the nature and evolution of social service policy making and implementation in Zambia.

As a case Zambia has a lot to offer. The country adopted multipartyism at the beginning of Africa's democratic wave and did so due to both significant foreign and domestic pressure. While many of the arguments made in chapter three are presented in terms of the likely impacts on responsiveness of a fully exogenously led transition, Zambia's case gives more insight into how exogenously influenced transitions may impact subsequent responsiveness when a relatively strong domestic movement is also present prior to the transition. ${ }^{43}$ Also, the larger quantitative literature has somewhat overlooked the impact that hybridity has had on social service responsiveness. Like

\footnotetext{
${ }^{43}$ Zambia is given a 1 on the exogeneity scale; which is a middle point between mostly endogenous and mostly exogenous.
} 
most African countries, Zambia seems to have consolidated its democratic progress in a state of regime hybridity. While hybrid regimes hold elections that may work to incentivize politicians to act on behalf of citizens' welfare, they also maintain elements of authoritarianism that may work to undermine responsiveness. Zambia is one case, which allows us to peer into the puzzle of how the democratic/authoritarian mixtures in these regimes impact responsiveness that the presence of multiparty elections is supposed to enhance. Finally, social service delivery and quality of life in Zambia has had a mixed record since the country introduced multiparty competitive elections. While some indicators measuring social service access and quality of life have changed positively, most have changed negatively since the country has introduced multiparty competitive elections in 1991, making Zambia a particularly interesting case to examine the political underpinnings of social service delivery. ${ }^{44}$

I find that while there were important initial strides made by Zambia's post-transition government to institutionalize a higher level of responsiveness in social services, later erosions in Zambia's checks and balances undermined these gains. Zambia's transition to multiparty politics led the country away from single-party rule into a state of evolving regime hybridity. Even as the government was holding regular multiparty elections, Zambia’s leadership was repressing opposition and consolidating the dominance of its executive branch, which has likely negatively impacted responsiveness in the country. Additionally, the introduction of multiparty competition failed to sweep away other barriers to achieving a responsive democracy, like systemic corruption, low capacity local government, and a disengaged public. Thus, despite two decades of holding regular multiparty elections, Zambians continue to be left without an effective channel to voice social

\footnotetext{
${ }^{44}$ Life expectancy has decreased by 6 years, the percent of people that are undernourished in the country has decreased by $2 \%$, the percent of people immunized for measles has decreased by $5 \%$, and infant mortality has increased by 6 percent, over the 1990 to 2005 period. In contrast, primary enrollment has increased by 14\%, and the number of doctors per capita has increased by 17 over the same period (World Bank Development Indicators)
} 
service needs to, locally elected leaders are largely incapable of responding to needs, and more capable policy makers lack the incentives to respond to demands in equitable ways.

This chapter is the result of in-country fieldwork during the Summer of 2010, when I conducted a series of in-depth interviews with policy makers, social service bureaucrats, members of the NGO community, representatives of foreign donors, and scholars, about the demand and supply of social services in the country as well as how social service policy has evolved and interacted with Zambia's political system. Specifically, these interviews paid particular attention to tracing the process by which Zambians articulate their need for education and health services, how policy makers receive this information, and their subsequent reaction to these needs.

Before describing changes in social service policy, I first provide a summary of the political dynamics in Zambia during and post its transition to multipartyism. This is to give the reader a basic foundation of the general political context of the period of social service delivery that I will be focusing on. The story of events that led up to the adoption of multiparty politics, and the later "hybridization" of political rule have been told more extensively elsewhere (see Rakner 2003; Bratton 1992, for examples). I then move on to describe how social service policy making and financing in Zambia has evolved in the post transition period. Here I also hypothesize about the political underpinnings of changes in social service policy as well as how these changes likely impact responsiveness in the country. Third, I discuss the state of other characteristics of Zambia's political system, which not only seem to be barriers to achieving a responsive democracy, but have also not been significantly impacted by multipartyism. Finally, I conclude with a broader discussion of what role exogenous pressures may have had in influencing the state of responsiveness in Zambia's democracy. 


\section{Becoming a Multiparty Hybrid}

"In fact, politics is the conduct of public affairs for private advantage"

Fredrick Chiluba, Zambia's second President ${ }^{45}$

Zambia returned to multiparty competition in late 1991, after 17 years of single party rule.

This was significant for Africa, as it was the first English speaking country to complete such a transition peacefully. The transition occurred over only a two-year period, with the first calls for multiparty democracy occurring in December 1989 and the first inauguration in December 1991 (Bratton 1992). President Kenneth Kaunda, the country's founding father, and his United National Independence Party (UNIP) were replaced by an opposition group called the Movement for Multiparty Democracy (MMD) and its leader, Fredrick Chiluba, who became president with 76 percent of the vote. However, in a similarly short period of time, the democratic nature of the Chiluba regime started to show signs of hybridization as it made several moves, which mirrored that of the rule of its old opponent.

\section{Replacing Single Party Rule with Multiparty Competition}

Domestic opposition to single party rule largely rose due to discontent over failed economic policies and their widespread impact on the standard of living in the country. During its first decade of independence, Zambia’s economy grew modestly, at about $2.3 \%$ annually (World Bank).

However, its heavy dependence on copper (copper made up $90 \%$ of its exports and $40 \%$ of its GDP throughout the 1970s and 1980s) proved to be an exceptional liability in 1974 when world copper prices fell (Rakner 2003: 53). A lack of diversification coupled with other economic drains, such as a pervasively large and inefficient state sector led to a sharp decline in average income. Per capita

\footnotetext{
45 (Graham 1994: 154)
} 
income fell from $\$ 615$ in 1974 to $\$ 238$ in 1986 (WBDI) ${ }^{46}$ and government revenue fell by 30\% between 1974 and 1984 (Larmer 2006: 297).

In light of the severe economic decline, the Zambian government had little choice but to turn to the IMF and World Bank. The government set about on a series of prescribed stability measures and, later, structural adjustment programs between 1973 and 1990 (see Graham 1994: 150 for a full chronological account of Zambia's relationship with the IMF and World Bank during this period). Economic policy conditionalities on IMF and World Bank financing during the early and mid-1970s were largely weak and lacked enforcement mechanisms; it was not until 1978 when the IMF attached a strict package of policy conditionalities on a US $\$ 250$ million dollar loan, which was, at the time, the largest IMF loan ever extended to an African country (Rakner 2003:54; Hawkins 1991: 844). The conditionalities and reforms adopted failed to produce policies that would address underlying economic problems and the government returned several more times to the IFIs for more economic help. "From 1978 onwards, the relationship between the IMF and Zambia was characterized by steady increases in borrowing, matched by even more stringent conditions" (Rakner 2003: 55).

As the Zambian economy continued to decline, its government became more desperate for external financing. This situation left the IFIs with more leverage in demanding policy reforms. However, many of the reforms came at a high political price for the ruling regime, which influenced the government's decision to abandon them at various stages of implementation. For example, reforms in 1985 called for the elimination of subsidies on maize and fertilizers, a decrease in price controls in the state sector, and significant reductions in public spending and the size of the civil service (Callaghy 1990: 292). "More than anything, the 1985 adjustment measures hurt the government's political base, the urban population and large public bureaucracy within the UNIP and

\footnotetext{
${ }^{46}$ Data is from World Bank's World Development Indicators.
} 
the state." (Rakner 2003: 58). In reaction to announcement of the reforms, waves of organized strikes overtook the country, marking the greatest outbreak of unrest Zambia had seen since independence (Rakner 2003: 59). The government's response was to abandon the reforms altogether in early 1987 (Lewis 1996: 106) and to follow its own, less politically risky, economic reform program (Martin 1993: 138). However, in 1989, the government recognized that its own plan was failing to produce results, and it returned again to the IMF in 1990 (Martin 1993: 138).

At home, economic dissatisfaction in Zambia was increasingly being translated into demands for a new government and multiparty politics (Rakner 2003: 63). Trade unions, particularly copper miner unions, had a history of political influence even prior to independence; these unions, led by the Zambia Congress Trade Unions (ZCTU) played a vital role in the independence movement itself, in the late 1950s and early 1960s (Meebelo 1986). ZCTU continued to be the most powerful non-state association in Zambia throughout the post independence era and its membership comprised roughly 70\% of Zambia's total workforce in the formal sector (Rakner 2003: 51). While in the first decade of independence, the ruling party, UNIP, was able to appease the union forces, the economic decline in the mid-1970s acted as a catalyst for trade unions to develop their role as the unofficial opposition to the single party regime (Rakner 2003: 51).

The deteriorating domestic environment was compounded by pressure from international donors. Rakner argues that the internal multiparty movement "only gathered momentum when the domestic opposition was supported by the international donor community" (2003: 21). ${ }^{47}$ International donors were becoming more cohesive regarding the economic and political conditionalities of financial assistance (Rakner 2003: 22). As discussed in other parts of this dissertation, the end of the Cold War marked a new consensus in this respect; bilateral donors

\footnotetext{
47 Members of the international community has beed described to have a visible and ongoing presence during the negotiations between the domestic opposition and the Kaunda regime (Bjornlund, Bratton and Gibson 1992). One example includes former President, Jimmy Carter, pushing the Zambian government to make changes in the electoral system. (Bjornlund, Bratton and Gibson 1992).
} 
started attaching democratic conditionalities to their aid. While Zambia did not receive overt threats of aid sanctioning by donors for its lack of political liberalization, arguably the international community at the time did not necessarily need to do so. The regime was already at a point where it was in desperate need of a financial lifeline. Even without being threatened with aid withdrawal, the ruling party and opposition were well aware that "the survival of any political regime in Zambia [was] dependent upon improving the country's international financial relations" (Rakner 2003: 22). ${ }^{48}$ At the time, improving its relationships with the international community, and with donors especially meant that the regime would be committed to liberalizing its political and economic systems. Thus, while there was definitely a domestically rooted opposition wherein genuine calls for a change in government and regime were heard, the international community reinforced such political change by giving any government in Zambia democratic parameters within which it must operate.

Dissatisfaction over the regime's handling of the economy culminated in 1990, a year that was particularly politically active and unstable. Explosive riots broke out after the government doubled the price of maize meal in June 1990, after it followed yet another set of IMF directed reforms (Bratton 1992: 85-86; Rakner 2003: 63). Instead of being exclusively focused at the economic reforms imposed, the riots and other civil disobedience took a largely political tone targeted at ousting Kaunda regime. "Thus, from July 1990 onwards, a broad coalition of the trade unions, students, academics, the business community and parliamentary back-benchers started to organize an alternative political platform for the reintroduction of multiparty politics" (Rakner 2003: 63). The trade union movement remained the organizational base of the burgeoning opposition. Under domestic and international pressure, the parliament changed the constitution to allow for multiple political parties in early December 1990, and the chairman of the trade union movement,

\footnotetext{
${ }^{48}$ The international community played a central role in the policy making process of the Chiluba regime. For example, the international donor community "was regarded as the final sanctioning body of economic policies" (Rakner 2003: 22).
} 
Fredrick Chiluba, was elected to head the Movement of Multiparty Democracy (MMD), the main political party that would face the Kaunda regime at the polls (Rakner 2003: 64). The seriousness of discontent with the economy and governance was finally felt in October 1991 when Chiluba won the presidential elections and MMD won 125 seats out of 150 in the parliament (Rakner 2003: 64). The new regime received a tremendous influx of foreign aid for its commitment to political and economic liberalization (Rakner 2003: 181).

\section{Hybridization of the Zambian Democracy}

Zambia's largely free and fair first multiparty elections marked a period of hope for the country. However, the democratic nature of the government started to deteriorate shortly thereafter, as its foundations were marred with an underdeveloped party system, institutional legacies from the previous single party rule, and devoid of any powerful domestic democratic watchdog. To this end, the donor community played an important role in marking the boundaries of democratic behavior. Donors reacted to signs of dramatic backsliding with threats of, or actual, aid revoking, and rewarded democratic concessions. Under this environment the ruling party seemed to play a game; it did what was necessary to remain in power, however undemocratic that action might be, and once the threat of losing power had waned, it made democratic concessions to win back the good graces of the donors.

The new ruling party, the MMD, was essentially a coalition of various groups, including professionals, intellectuals, and business people, as well as organized labor and many members of the former ruling party that defected when it was clear it might be unseated (Sandbrook 2000: 34). In large part, the glue uniting these groups under the MMD banner was their shared disillusionment with the economic decline and governance of UNIP. Soon after taking office, however, the diversity of interests that were contained in the MMD started to manifest itself in several different factional struggles (Sandbrook 2000: 34). Additionally, the MMD’s rise to ruling party status left an 
oppositional void, until most recently. UNIP maintained its base in limited areas (like the Eastern province), but along with losing the election and many of its parliament seats, it had lost many prominent members to the MMD. Further down the road, UNIP would slowly dissolve, to be unseated by other opposition parties as the main opponent to the ruling party. With the dawn of multiparty competition, came the proliferation of several other smaller opposition parties, and over time disillusionment and defection with MMD rule has led to an increase in the creation of new parties by old MMD politicians (Rakner and Svasand 2004: 53). Most notably, for example is the Patriotic Front (PF), a party set up by Zambia's current president, Michael Sata, who was a prominent MMD politician that defected when the presidential nomination in 2001 was given to a different MMD member. ${ }^{49}$

At the beginning of its rule, the MMD was given a relaxed institutional setting. By many accounts, a lack of adequate checks on the MMD's power and, therefore, their ability to make political moves which echoed that of the UNIP government, can be attributed to the control that UNIP had in navigating the transition. "UNIP managed to control the transition in that only minor modifications to the existing constitution preceded the election in October 1991. Although Kaunda and UNIP lost the election, the incoming MMD government inherited a range of repressive powers from the former one-party state" (Sandbrook 2000: 26). For example, Kaunda maintained a "state of emergency" throughout his rule, a topic that was not only opposed by the MMD during the 1991 campaign, but adopted by Chiluba in 1993 (for a much shorter period of time) in response to threats of UNIP resurgence (Rakner 2003: 105). The MMD used and still uses state resources to help campaign on behalf of MMD candidates, another practice that the former ruling party engaged in (Rakner 2003: 106). As early as late 1993, the initial tolerance of various views within the Cabinet was largely gone (Nordlund 1996: 132). And although MMD campaigned based on promoting

\footnotetext{
49 “Michael Sata: Zambia's 'King Cobra' finally strikes,” BBC News, 23 September 2011, viewed on: http://www.bbc.co.uk/news/world-africa-15034694
} 
transparency and decreasing corruption, complaints of corruption within the government have become increasingly prominent (Rakner 2003: 107).

The political events that preceded the second national election were most troubling for the status of the Zambian democracy. At the time, UNIP remained the largest opposition group to MMD, and Kaunda, the ex president was planning on competing in the upcoming election. In anticipation of this, the MMD government passed a constitutional amendment, which barred the ex president from competing. Under the pretense of nationalism, the MMD's amendment required that the parents of a presidential candidate would have to be born in Zambia, and Kaunda's parents were from Malawi (Kees van Donge 1998). This move sparked both domestic and donor opposition, and ultimately resulted in decreased aid from donors to pressure the regime (Kees van Donge 1998). Other issues surrounding the 1996 elections signaled that elements of the democratic experiment in Zambia had been abandoned. Voter registration was fraught with irregularities and delay, publicly owned media was used to the advantage of the MMD candidates, and the ruling party used government vehicles to campaign and relied on development funds and private goods to attract supporters in rural areas (Baylies and Szeftel 1997). Chiluba won the election in a landslide victory of 73 percent of the vote and MMD captured 131 of 150 parliamentary seats (Rakner 2003: 110).

It was also during the second election that the power of the executive also increased tremendously, with "the creation of a presidential discretionary fund outside parliament scrutiny; various special desks in the Presidential Office; and large supplementary payments to the Presidential Office” (Rakner 2003: 186). Also the president increasingly made unilateral policy decisions and expelled members of his party for dissent. The inordinate power of the executive would continue to be a defining characteristic of the Zambian government in future administrations (van de Walle 2002; Rakner 2003; VonDoepp 2005; Prempeh 2008). The "Big Man Syndrome" it seemed, would continue to plague the Zambian democratic experiment. 
While the MMD retained power, the 1996 elections had tarnished Zambia's reputation as being a functioning democracy. "Necessitated by the substantial cuts in donor support, the reelected MMD government began a process of regaining democratic credibility in early 1997” (Rakner 2003: 111). The main changes made were involved creating several semi-autonomous "institutions of restraint," including an Electoral and Human Rights commissions and delinking the Anti Corruption Commission from the presidency. However, once again, these "democratic" reforms were heavily promoted by the international donor committee (Rakner 2003: 111).

During Chiluba's second term, the country experienced continued political oppression, in the form of raids, economic threats, tax harassment and outright violence on independent media, NGOs, and political opponents, including a situation where the police opened fire on Kenneth Kaunda at a political rally (Rakner 2003: 112). During the end of his second term Chiluba started to initiate a movement to change the constitution to allow him to run for a third term, a campaign that was met by unprecedented opposition both domestically and internationally (Venter 2003: 12). The blocking of the move was a promising sign for the durability of the rule of law and illustrated again the leverage that donor's had in influencing Zambian politics. However, that the President campaigned for such a change also illustrates the unconsolidated nature of Zambia's democracy. Having been blocked from running for a third term, Chiluba handpicked his successor, Levy Mwanawasa, and in the next national election, amidst allegations of massive vote-rigging and electoral fraud, the MMD candidate narrowly defeated an opposition party candidate (from UPND) by 33,997 votes (Venter 2003: 12).

When Mwanawasa was returned to power for a second term in 2006, for the first time the fractionalized opposition obtained more seats in parliament then the ruling party (76 seats to various opposition parties to 74 seats of the MMD), which might be taken as a sign of increased endogenization of democracy in Zambia. Additionally, in general, Mwanawasa's rule was viewed to 
be an improvement in terms of authoritarianism and corruption from the Chiluba regime. However, his commitment to fight corruption waned towards the end of his time in office, and he illustrated some of the same repressive powers while in office. For example, in early 2004, he issued a deportation of a British citizen who had criticized the president in the news by comparing him to an elephant. ${ }^{50}$ Additionally, critics argued that he tried to manipulate a constitutional review (Larmer 2009:128).

Following Mwanawasa's death in 2008, Rupiah Banda was elected into office, another MMD politician. Again, there were allegations of electoral fraud (Freedom House 2010). However, at this point, the oppositional climate started to show signs of shifting. Michael Sata, the PF's candidate, only lost to Banda in the 2008 presidential campaign by 2 only percentage points. ${ }^{51}$ This was a promising sign that the destructive fractionalization, which characterized the past opposition parties, was coming to an end. During Banda's time in office, complaints of corruption continued, and disillusionment with the MMD’s long rule continued to spread. In 2009 and 2010, foreign aid for the health sector was suspended following reports of corruption scandals in the ministry of health. Also, the Banda government took a number of aggressive and sometimes violent measures to repress the opposition and civil society (Freedom House 2010).

The 2011 Presidential election marked another milestone for Zambia's democracy; after 20 years of MMD rule, Michael Sata, of PF, was elected into office. While this was clearly a case of party turnover, the Sata was a well-known and veteran Zambian politician. He rose to prominence in the ruling UNIP party under Kenneth Kaunda, but then defected to the MMD shortly before Chiluba won the presidency in 1991. He then broke away from the MMD party, after Mwanawasa was made the presidential candidate of the party in 2001. At this point, Sata set up his own political

\footnotetext{
50“The Insult” The Guardian. 6 January 2004, viewed on: http://www.guardian.co.uk/media/2004/jan/07/ pressandpublishing.g2

51 “Michael Sata: Zambia's 'King Cobra' finally strikes,” BBC News, 23 September 2011, viewed on: http://www.bbc.co.uk/news/world-africa-15034694
} 
party, the Patriotic Front. ${ }^{52}$ Sata also contested three presidential elections before winning in 2011, under the PF banner, each time gaining a higher percentage of the votes.

What the 2011 election means for Zambia's democracy is up for interpretation. On the one hand, Sata's victory marks the crystallization of a popular opposition party, and maybe some indication of an endogenization of democracy. Put differently, 20 years of practicing multiparty politics in Zambia may have, not only institutionalized the formal rules of democracy, but also made inroads in generating a domestic democratic movement, which would explain the 2011 presidential party turnover. However, on the other hand, several other features of this particular outcome indicate that it is unlikely that this victory of democratic institutions will change how politics works on the ground. First, the campaign leading up to the election was again characterized with MMD repression and their unfair use of state funds to campaign. This indicates that even up until this election, there lacked institutional checks on the ruling party's abuse of power. There is also some speculation that Sata may have had to rely on foreign finance from Taiwanese firms to tip the financial balance more in his favor to win office. ${ }^{53}$ This is a clear sign of the need to rely on exogenous actors to combat poorly institutionalized checks on the ruling party within the country. While it might be tempting to write off these issues as being features of the previous regime, there is equally reason to suspect that the weak institutional environment, which underscored both the use of state funds on behalf of the MMD and the reliance on foreign finance from PF, will persist with Sata in office.

Additionally, while Sata clearly ran as an oppositional candidate, there was, arguably, not much that can distinguish his candidacy from Banda, besides the MMD label. Sata's move away

\footnotetext{
52 "Michael Sata: the Victoria station sweeper turned Zambia presidential hopeful” the Telegraph. 21, September 2011, viewed on: http://www.telegraph.co.uk/news/worldnews/africaandindianocean/zambia/8777561/ Michael-Sata-theVictoria-station-sweeper-turned-Zambia-presidential-hopeful.html

53 “China's stake in Zambia's election” BBC News, 18 September 2011, viewed on: http://www.bbc.co.uk/ news/worldafrica-14952240
} 
from the MMD to form the PF is often framed as an opportunistic move to create a political party vehicle that would give him access to the presidency. ${ }^{54}$ The two parties, MMD and PF, are basically indistinguishable in terms of party platforms, and Sata's candidacy was mainly based on making vague pledges to put more money in the pockets of voters. ${ }^{55}$ Rhetorically, the campaigns of both Banda and Sata focused on personal insults of the other, and relied less on distinguishing themselves in terms of their different policy platforms. ${ }^{56}$ Sata's election is seen as more of an expression of people's disillusionment with 20 years of MMD rule, and less to do with the choice of new policies that Sata advocated for. ${ }^{57}$ Thus, while Sata's election is a sign of an institutionalized electoral system, it speaks less to the ability of Zambia's party system to offer voters meaningful differences between parties and from the past.

Zambia's particular breed of hybridity was born out of a domestic and internationally pressured transition, which resulted in a weakly institutionalized party system, dominant executive branch and other legacies from the era of single party rule, like pervasive corruption. These elements operated within the confines of a formal multiparty democracy, largely reinforced by international donors through pressures and threats of imposing political conditionalities on foreign aid, as domestic democracy proponents were relatively less powerful in the post transition period. While at various points the donor community exercised political conditionality over issues such as corruption and conditional reform, (Rakner 2003: 182) as others have pointed out elsewhere (Uvin 1993; Brown 2005), donors are naturally limited in the extent to which they can demand political change through

\footnotetext{
54 "Michael Sata: the Victoria station sweeper turned Zambia presidential hopeful” the Telegraph. 21, September 2011, viewed on: http://www.telegraph.co.uk/news/worldnews/africaandindianocean/ zambia/8777561/Michael-Sata-theVictoria-station-sweeper-turned-Zambia-presidential-hopeful.html

55 "Michael Sata: the Victoria station sweeper turned Zambia presidential hopeful" the Telegraph. 21, September 2011, viewed on: http://www.telegraph.co.uk/news/worldnews/africaandindianocean/ zambia/8777561/Michael-Sata-theVictoria-station-sweeper-turned-Zambia-presidential-hopeful.html

56 "Pre-election Media Analysis: Zambia’s Presidential Election.” Consultancy Africa Intelligence. 2 September 2011, viewed on: http://www.consultancyafrica.com/index.php?option=com_content\&view=article\&id =844:pre-election-mediaanalysis-zambias-2011-presidential-elections-\&catid=42:election-reflection\&Itemid $=270$

57 “Michael Sata: Zambia's 'King Cobra' finally strikes,” BBC News, 23 September 2011, viewed on: http://www.bbc.co.uk/news/world-africa-15034694
} 
revoking aid. Especially in Zambia, donors insisted on the implementation of both economic and political liberalization. Struggling with the question of which agenda was most important, bilateral donors were reluctant to use their economic leverage to punish the regime's democratic pitfalls, and largely only responded with aid suspension when there were dramatic setbacks, as in 1996. This left elites with room to maneuver; as long as it showed commitments to the regularization of multiparty elections and economic liberalization, it could act undemocratically in other ways, still maintain donor support, and political power. More recently, Zambia's formal electoral institutions have been tested, as signified with the 2011 presidential party turnover. While the election's outcome calls for some optimism regarding the institutionalization of Zambia's formal democracy, there are still several reasons to be skeptical of what this turnover may mean for inducing a more responsive democracy.

\section{Social Services and Political Change in Zambia}

Competitive multiparty systems are expected to provide a better quality of life and higher levels of social services because their leaders fear being voted out of office (Deacon 2003, 2009; Lake and Baum 2001; Bueno de Mesquita et al. 2003; Ghobarah, Huth and Russett 2004). However, as argued in chapter 3, there are a number of reasons why the relationship between regime type and quality of life is not likely to always be entirely linear. The democracy-quality of life relationship implicitly assumes that citizens have an avenue to express policy needs, that they will do so, that they will use their vote to punish and reward policy makers based on their performance in providing social services (among other things), that elected leaders will have control over development policy, and that they will be incentivized to redistribute state resources in a manner which benefits the 
general population. ${ }^{58}$ How has Zambia's electoral democracy functioned with respect to these assumptions? Has adopting multipartyism impacted social service delivery? And, finally, how has the erosion of democracy impacted social service delivery?

The introduction of multiparty democracy led to a large formal institutional change in social service delivery, namely the adoption of the Local Government Act. Among other things, this Act aimed to institutionalize a more responsive government by delinking the ruling party from the government and establishing democratically elected local governments tasked with providing the vast majority of social services. However, Zambia's reversion to authoritarianism, or hybridization, also had an impact on several aspects of social service policymaking, which undercut the responsiveness of Zambia's system to citizens' needs. Additionally, multiparty competition failed to change other features of political life in Zambia, like corruption and the absence of an actively involved citizenry, both of which continue to act as barriers to incentivizing politicians. In effect, Zambians are largely left without an avenue to voice their social service demands, and elected leaders, for a number of reasons, are not capable and/or lack a willingness to respond to the social service needs of their constituents with more effective coverage and higher quality services.

\section{Regime Change and Local Government}

Today, almost all social service provisions are tasked to local government in Zambia. Under single party rule, however, local government largely filled the role of providing the ruling party with an active presence in all districts and at the village level (Chikulo 2009:100). In fact, during this time, local and central government were so highly politicized that all administrative structures were essentially merged with the ruling party (Chikulo 2009: 100). Political office was accessible to only

\footnotetext{
${ }^{58}$ Although, some of these features of a polity might be more important than others to tie democratic rule to a higher quality of life. For example, citizens might not need to express policy demands or vote based on social service performance. As long as policy makers perceived that they might be voted out of office for not working to provide services and they had control over services, the democracy-quality of life linkage might still hold. Arguably, a fear of being voted out of office is more likely to be present when the other conditions hold as well.
} 
high ranking and loyal ruling party members. With the transition to a multi-party democratic system came important legislation which would work to undermine much of how the former one-party system operated. The MMD campaigned on democratizing governance and separating party politics from government administration. On a wave of democratic rhetoric and an initial period of commitment to the democratic experiment, just 8 months after the constitution was changed to allow multiple parties to compete, parliament passed the Local Government Act (LGA) in August 1991. The LGA officially separated the ruling party from civil service and state apparatus and reintroduced measures to democratize local government. Unlike before, with the passing of the LGA, every citizen who was registered to vote were then also given the opportunity to stand for election or vote for the candidate of his/her choice, irrespective of political affiliation (Chikulo 2009: 100101).

The LGA also provided a formal structure to local government that was not necessarily as well defined prior to its passing. Accordingly, Zambia is divided into nine provinces, which are further divided into 72 districts, and further, still, divided into 1,456 wards. The LGA requires that every five years, local councilors are voted into office, one per ward. ${ }^{59}$ Each district was to have a District Council. Originally, in 1991, District Councils were made of all local councilors in the district, and in rural areas, two representatives which are appointed by all the traditional chiefs in the district (in 1992, the MPs of the district were also given a seat on the council). District Council meetings can be attended by anyone, and are one of the official avenues that Zambians have to voice policy needs. The District Council is formally tasked with implementing development policy, and coordinating the development efforts of various ministries within the district. Additionally, and especially important to the purposes of this chapter, the LGA also defined the role that local government would take in social service provisions. District Councils would be delegated with

\footnotetext{
${ }^{59}$ However, there exists no effective development planning at the ward level.
} 
providing almost all social services to their constituencies. Specifically, the Local Government Act of 1991 outlines sixty-three functions of local councils. These functions can be categorized as general administration, advertisements, agriculture, community development, public amenities, education, public health, public order, and sanitation and drainage (Lolojih: 5).

As mentioned in chapter 3, localizing or decentralizing social service provisions as the LGA seemingly did, is held up by many as responsiveness inducing policy. Theoretically, delegating lower levels of government with social service policy gives citizens greater access to those whom make decisions about services, which allows more opportunity for citizens to articulate policy needs (Tommasi and Winshelbaum 2007), creates incentives for local policy makers to respond to local needs and aids in rectifying a general problem of inequalities in the distribution of state resources (Faguet 2004; Besley and Coate 2003: 2628; Bardhan and Mookherjee 2005). ${ }^{60}$ In many ways, and in line with this logic, the LGA was read as a step toward the institutionalization of responsiveness within the new competitive multiparty order. The closest form of elected government to citizens, councilors and the district council, were officially responsible for local service provisions. District council meetings would be accessible to citizens as an outlet to express policy needs. Thus, local level politicians would, theoretically, have an electoral incentive to deliver on services and respond to expressed needs. And finally, citizens would have an opportunity to hold elected officials accountable at the polls.

However, local government in Zambia failed to develop into a truly responsive body. When in power, UNIP held a monopoly on all matters of government and was deeply involved in implementing any development policy at the local level (Graham 1994: 151). With it removed from power, Zambia experienced an institutional vacuum and local level government never gained the

\footnotetext{
${ }^{60}$ Indeed decentralization has been associated with higher levels of social service provisions in some studies (Faguet 2004; Khaleghian 2004; Enikolopov and Zhuravskaya 2007), however, others have pointed out that decentralized systems, in certain settings, might be prone to higher levels of corruption than centralized systems (Bardhan and Mookerjee 2000), which would negatively impact accountability in a given political system.
} 
capacity needed to fulfill the tasks delegated to them under the new order. Instead, MMD leadership found it in their political interest to increase the central government's control over development policy. Thus, its level of responsiveness in social services suffers from both the legacies of the former one-party state and Zambia's reversion towards an executive-dominant governing system in the post transition era.

\section{Expanding a Central Influence in Local Level Social Services}

While the LGA seemingly institutionalized a level of local responsiveness in social service delivery, later amendments to local governance structures have undermined that effort. It is through these additional changes that Zambia's eroding democracy and increasingly dominant executive branch began to resonate within the country's social service responsiveness. One of the first amendments to the LGA was in 1993, at which point District Development Coordination Committees (DDCC) were created. The DDCCs were to serve as " technical advisory committees whose function would be to provide a forum for dialogue and co-ordination on development issues between the local authority, line departments, donors and NGOs in each district" (Mukwena 2001: 16). ${ }^{61}$ In essence, the DDCCs were tasked with development policy planning at the district level, a job that was originally given to the District Councils, whom were now only in charge of providing services (Chikulo 2009: 104). More important to the issue of possibly displacing local responsiveness is the makeup of the DDCCs. A DDCC is comprised of the heads of central government departments at the district level and other development agencies represented in the district. Giving control of social service policy planning to this committee meant a break in the accountability chain; none of the locally elected officials would control social service policy planning at the local level, and instead the majority who would, were bureaucrats that represented central government departments. Citizens of local constituencies lost an electoral leverage over policy planning, and policy makers at

\footnotetext{
${ }^{61}$ However, while these bodies may have been given different formal tasks, in practice I found that the roles of the two groups overlap and are sometimes vague.
} 
the district level no longer had an electoral incentive to respond to local needs. Additionally, because the central government departments (ministries) are held mostly accountable to the executive branch (this is elaborated upon further later), this policy change also served to realize an expanded the role of the executive branch into local social service policy planning. Theoretically, DDCC members would be more loyal to the needs of the central government when planning policy, to which they owed their employment.

The creation of the District Administrator position is another example of the central government's encroachment on local level development planning. This position was created in 1999, three years after the Chiluba led government undemocratically edged out Kaunda from running in the second election and well into a time of democratic erosion in the country. With the District Administrator position, the executive branch was able to assert its influence over district matters in a much more overt way then before, when it was somewhat prevented from doing so under the original LGA. The District Administrator was to be, and is, the executive head of the District Council, a member of the DDCC and is tasked with overseeing development plans within the district. It is a civil service position that is appointed directly by the president and reports to the presidential office (Rakner 2003: 113). District Administrators were provided with vehicles and offices outside of formal local government structures and "were placed in control of the crucial Constituency Development Funds that provide much of the small-scale finance for government projects," (Rakner 2003: 115). Due to this control, the position further undercut the capacity of local governments to control development policy autonomously, which worked to reduce local level responsiveness even more. Additionally, the position echoed a characteristic of the previous oneparty regime, as it was heavily politicized. Most District Administrators were recruited from "the party cadres of the ruling MMD” (Mukwena 2001: 13). Such recruitment trends worked to further 
distort the incentives of development policy at the district level to reflect the political needs of the ruling party.

Like the LGA, other legislation has been passed in Zambia to seemingly make more inroads towards more meaningful decentralization and responsiveness. For example, in 2002, the Decentralization Implementation Programme (DIP) was adopted to assist in more meaningful measures to decentralize and strengthen the capacity of the local government. However, not much meaningful progress has been made in its implementation. The slow pace of change towards more meaningful decentralization has been largely blamed on political disagreements over the final institutional arrangements that will be used in its implementation (PDM 2007). However, the lack of domestic political momentum to adopt more meaningful decentralized institutions may be a function of the exogenous nature of much of the pressures to decentralize, and the lack of domestic political will to implement decentralization policies.

As discussed in chapter three, decentralization is one policy that donors have heavily promoted so as to induce responsiveness within recipient countries, among other things. Zambia is a good example of this; donors promoted decentralization and made it clear that decentralization efforts would be financially supported. For example, the UNDP provided immediate support to Zambia's Decentralization Secretariate when it was established, and The World Bank, and several other bilateral donors have doled out support for decentralization efforts in the country (PDM 2007). Thus, there is strong element of exogeneity when it comes to Zambia's decentralization policy. As discussed in chapter 3, while ruling elites might be willing to adopt formal amendments to decentralize the government to appease eager donors and IFIs, actual implementation requires domestic political will. The stalled nature of the decentralization project in Zambia illustrates the lack of domestic political will to implement meaningful decentralization. Decentralization is designed to reduce the ability of the central government to coordinate and control development 
efforts. Thus, incumbent leadership will likely not find the policy in their own interest without having strong domestic pressure to back decentralization efforts. Additionally, as discussed in chapter 3, donors are ill equipped to monitor or enforce suggested policy transformations, like decentralization. Thus, the exogeneity of decentralization efforts in Zambia may help to explain why domestic efforts to decentralize has been somewhat stalled.

The original LGA and subsequent "responsiveness" related legislation envisioned a more responsive social service planning structure than what exists today. In essence the subsequent amendments to the LGA have hollowed out the capacity of local government to work autonomously from the center and took away citizens' ability to more directly influence local level policy planning. Other policies, like decentralization, have stalled in their implementation and have remained ineffective at returning higher degrees of responsiveness. While the structure of development planning has certainly evolved in conjunction with the erosion of democracy in Zambia, social service financing has largely remained the same since the transition. As I discuss next, this continuity, unfortunately, also undermines local responsiveness.

\section{Keeping the Purse at the Center}

Zambia's social service financing scheme also undermines local responsiveness and is vulnerable to being heavily politicized as it too gives a lot of leverage to the central government, and executive branch, specifically. For example, at the local government level social service financing is supposed to come from two sources: (1) local revenues raised by district councils through, for example, the collection on rents of government owned buildings, license fees, and market levies, (Tordoff and Young 1994) and (2) transfers from the central government. ${ }^{62}$ The latter is supposed to be the local government's major source of finance. (Chikulo 2009: 103). "The transfers are firstly, the means by which the central government shares taxes with councils, and secondly, provide a

${ }^{62}$ According to the LGA 
conduit through which various grants from sector ministries are disbursed to enable councils to undertake delegated functions on their behalf' (Chikulo 2009: 103). ${ }^{63}$ However, by requiring that local governments rely on the central government to fund the majority of projects or give general grants, local government become financially unable to respond to social service needs autonomously. This disrupts the accountability cycle which the LGA purported to institutionalize, as citizens are unable to hold locally elected officials accountable for a lack of funding due to essentially the central government's planning.

The problems that this lack of local autonomy over social service finance creates for institutionalizing responsiveness becomes more apparent when one moves further up the chain of development planning in Zambia. Once district-level planning is approved by District Councils, these plans are then passed on to the provincial level. At the provincial level sits a Provincial Minister, the political head of each province, and the Provincial Permanent Secretary, the head administrative officer. The Provincial Minister is a presidential political appointee while the Provincial Permanent Secretary is a civil servant. The provincial level also has a development committee, the Provincial Development Coordination Committee (PDCC) which is tasked with "coordinating the planning, implementation, and monitoring of developmental activities of the province" (CRS 2007:13). PDCC members include all provincial heads of government ministries and departments, donors with projects in the province, and representatives of NGOs (Mukwena 1999: 11). The Provincial Permanent Secretary is the chairperson for the PDCC. Thus, provincial level planning is led mostly by people who report to central government ministries, not to a local constituency.

\footnotetext{
${ }^{63}$ Additionally, development projects are funded through constituency funds for development projects in parliamentary constituencies (Mukwena 1999: 7). However, these funds are first given to the MP of the district, and MPs appoint four community leaders to the committee that decides how the resources should be used. "Properly channeled and controlled, these additional funds would have been undoubtedly beneficial to the local authorities and the communities which they served. The danger was that, for personal and political reasons, MPs might seek to divert funds to projects which would further their political careers to the detriment of other, more useful projects." (Mukwena 1999: 7).
} 
Further still up the development planning chain, provincial development plans are then considered to be consultative tools to be incorporated into the National Development Plan. Ultimately a "steering committee of Permanent [Ministry] Secretaries, chaired by the Secretary to the Cabinet," superintends the entire National Development planning process (FNDP 2006: 2). Zambia's national development plan outlines the government's development goals, strategies to achieve such goals and outlines a yearly itemized budget for five years as to how the government will fund such strategies. The Fifth National Development Plan (FNDP 2006) was drafted to cover 2006-2010. ${ }^{64}$ The official structure, the process by which Zambia achieves a national development plan, seems to be "bottom-up" in terms of incorporated district level development plans into provincial plans and provincial level plans into the final national level plan. Indeed, the produced national development plan does seem to articulate how the nation will fairly tackle the needs of each province and district. However, in practice, the funding of the national development plan not only leaves room for the central government to control how and where social service funding is given in the country, but also incentivizes the politicization of social service funding.

Several people I spoke with called the National Development Plan a "wish list," which might be drafted more in line with what donors may hope the country to strive for, than what is actually realistic for the country to achieve. National development plans in Zambia are chronically underfunded. Underfunding results from overestimating projected revenues and/or a decline in resources available due to many reasons, including corruption. The various ministries (Ministry of

\footnotetext{
64 The drafting stage at the central level also involves the consultation of Sector Advisory Groups (SAGs). "Members of SAGs include Government officials, representatives of cooperating partners, and representatives of civil society organisations. Consultants were also hired to support the work of the SAGs" (FNDP 2006). A Steering Committee of Permanent Secretaries oversees the entire FNDP planning process (FNDP 2006). This process includes a series of meetings which identify national priorities through the Ministry of Finance and National Planning (FNDP 2006). Once a draft is released, a "national stakeholders' workshop" was held to discuss the Plan and implications. Finally, after the input from the stakeholders' meeting is folded into the plan, the plan is sent for approval by the Cabinet and, once approved, published (FNDP 2006).
} 
Development and Finance, Ministry of Local Government, Ministry of Education, Ministry of Health...etc.) that fund development and social service projects are routinely faced with this problem of underfunding planned budgets. This gap between what is planned and what is able to be funded necessitates "prioritization" within the planned budget. The largest potential for a politicization of social service funding lies within this "prioritization," because what the ministries choose to finance, or prioritize, can be politically motivated by the ruling party's needs, and still be rationalized as being a part of official development planning. Additionally, Permanent Secretaries of each ministry, whom essentially oversee the final National Development Plan, are appointed by the president of Zambia, and can be terminated and replaced at any point by the president of Zambia. Thus, they have an institutionalized incentive to "prioritize" the funding of social services and general development policy in geographic areas that are politically advantageous to the ruling party.

This political incentive to appease the ruling party, or president, is exacerbated when the executive branch becomes more dominant. As discussed earlier, the government in Zambia started to show signs of hybridization as early as before the second multiparty election, as the president increasingly made unilateral policy decisions and expelled members of his own party for expressed dissent against his policies. With the executive branch increasing its dominance, an atmosphere was created that heightened the probability that development and related social service policies would be targeted towards the regions in the country that would likely please the political aspirations of the president and ruling party, and not necessarily towards those regions which expressed the most need. For example, some note that the MMD led government has systematically neglected the Eastern province in Zambia due to political favoritism, as the Eastern province was an UNIP stronghold post transition. As a result, the Eastern province exhibits comparatively much lower levels of education and access to health care than other provinces (Milimo 1991: chapter 2). 


\section{A Low Capacity Local Government}

Centrally controlled financing and an increasing sense of the center's encroachment over development planning depleted the capacity of local government to act autonomously in response to social service needs in Zambia. Lacking funding, local government in Zambia fell bankrupt and low and unreliable funding attracted few qualified candidates to ultimately serve as distributor of local services. Instead, local officials usually have low levels of education, little motivation to do work toward achieving policy goals and are generally ignorant about what a councilor's actually entails (Lolojih: 7). In fact, in the most recent wave (2008) of the Afrobarometer survey almost 55\% of Zambians surveyed felt that their local councilor is unqualified in terms of how much they care about their community, 56\% felt that their councilor did not have enough experience at managing public service programs, and a quarter of Zambians surveyed thought it was not likely that they could get their district councilors to listen to their concerns. Arguably, low and unreliable salaries somewhat incentivize the use of an official position to extract rents from citizens. Indeed, close to $70 \%$ of Zambians surveyed thought that their local councilor was not honest in handling public funds, over $85 \%$ felt that local councilors used government revenue for private gain, and similarly only $8 \%$ of Zambians felt none of their local councilors were involved in corruption (Afrobarometer 2008). While these figures may be partly a function of social distrust, they may also be a reflection of the persistence of corruption among District Councilors. If so, we can that such graft further decreases the District Council's capacity to respond to social service needs. As much as the MMD campaigned to root out corruption in Zambia before the transition (and every political party has campaigned on this ever since the transition), the adoption of a multiparty system has, by many accounts, not impacted the prevalence of corruption in the government. ${ }^{65}$.

\footnotetext{
${ }^{65}$ In fact, many corruption charges have been targeted to those within the Chiluba regime (and many to Chiluba himself), (Kees van Donge 2009)
} 
The transition to multiparty competition did not translate into mechanisms whereby local government was emboldened enough to respond autonomously to social service demands. Unfortunately Zambia is like many African countries in that its local level government is plagued with low capacity to respond to needs (Smoke 2003). The persistence of a low capacity local government, however, should also be read as a political intention by the ruling party and central government. Empowering other levels of government to act more autonomously potentially detracts from the control that the central government can exert over the allocation of social service resources.

Zambian Voters

If elected leaders are to be held accountable to provide social services that their constituents demand, citizens should not only have an outlet to articulate policy demands, they should do so. As discussed earlier, Zambia's government institutions do not provide an effective avenue for citizens to demand social service goods. While this incapacity can probably partially explain low levels of citizen involvement and demand articulation, there may be other factors at play. For example, Zambians might be less prone to voice policy demands due to cultural norms. The oppressing effects of colonialism and one-party rule could have impressed Zambian political culture with a sense of passivity; instead of interacting with the state through elected officials, Zambians may feel that the state is supposed to paternally take care of them, or that they do not yet have a role in actively engaging with government. "Indeed one-party rule inculcates a patrimonial political culture in which people come to believe that their well-being depends on attaching themselves to the coattails of powerful political leaders" (Bratton 1992: 93). Such political culture reinforces loyalty, rather than opposition and dissent, and would not have been changed with the adoption of multiparty elections. As discussed earlier the international community and a domestic democratic movement both produced the change in government. However, the role the international 
community played was large, and the domestic democratic movement in Zambia was largely confined to the urban areas (Lusaka and the Copperbelt). Thus, and especially elsewhere in the country, voters may not have felt empowered by the change in government. Indeed, $65 \%$ of Zambians surveyed agreed with the statement "people are like children; the government should take care of them like a parent," and disagreed with "government is like an employee; the people should be the bosses who control government" (Afrobarometer 2008). Of course, cultural attitudes are also informed by political institutions. Because Zambians lack an avenue to effectively voice policy demands and hold policy makers accountable, much of the population might feel inappropriate with viewing their role as a Zambian citizen as one that can or should keep the government accountable.

Politicians are more likely to feel credibly threatened to be voted out of office for their performance on social service policy if when voters vote, they do so, at least partially, based on social service policymaking. Like in most democracies, citizens base their votes on a number of issues in Zambia. However, like most African countries, and other developing countries, several characteristics of Zambia's voting population, work against social-service based voting from occurring in Zambia. It is estimated that $30 \%$ of Zambians are functionally illiterate and that $68 \%$ of the country live at or below the poverty line (World Bank 2008). These demographics make voters vulnerable to believing misinformation about who can bring development projects and taking small gifts in return for their votes. Zambia's high rates of poverty make the voting population more vulnerable to vote buying. Many local campaigns are won and lost based on the items the candidate is able to distribute to local populations, like milli meal, chitenge cloths, alcohol and other food. In fact, in the 2005-06 wave of the Afrobarometer, more than $90 \%$ of respondents in Zambia reported that politicians offer 'gifts' to voters during election campaigns “often" or "always" (Afrobarometer Network 2006). Gifts illustrate the permanence of neo-patrimonial politics amid the introduction to formal democratic institutions. Reforms, like decentralization, only deal with a portion of the state; 
the way politics works is not really altered. Such campaigning, and responsive voting, again works to decrease the proclivity of citizens holding elected leaders accountable based on social service policy performance.

Ethnic considerations also seem to be prominent in vote choices in Zambia. According to Dowd and Driessen (2008) who estimated the proclivity of people to vote along ethnic lines among the Afrobarometer survey respondents in the Afrobarometer surveyed countries, Zambia exhibits the second highest level of ethnic voting among this group. 36\% of Zambians surveyed were estimated to vote along ethnic lines, which was higher than Kenya's 35.8\% and only less than Benin's 41\%. To the extent that Zambians are voting based on ethnic considerations, and abandoning considerations of social service policy performance, elected officials will not be particularly fearful that they will be voted out of office for social service policy performance. Although, this is a factor that will be more prominent in national elections than local ones (due to

the likely higher ethnically heterogeneous candidate pool at a national level, as compared to the likely homogeneity of candidates at a local level).

The effects of poverty and low education, as well as the prominence of ethnic identity considerations in voting decisions are all factors which seem to be carryovers from the era of the one-party state in Zambia. In other words, they were not impacted by multiparty politics in a way which would decrease the likelihood that they would be barriers to incentivize politicians to provide services.

\section{Alternatives in the Party System}

On a national scale, Zambia's party system, since the transition to multiparty politics has evolved from being characterized by the presence of a dominant ruling party, Movement for Multiparty Democracy and a fractionalized and weak opposition to now being successfully challenged by the current President's party, Patriotic Front. However, as mentioned previously, the 
Patriotic Front and Michael Sata, as a candidate do not necessarily represent a change or an alternatively different choice from the MMD party platform or the actions of the MMD leadership. The policy platforms of both parties are vague and for all intents and purposes, indistinguishable; and Sata was a former MMD politician, who by some accounts did not defect to form the PF because of a clear ideological differences, but instead because his road to the presidency was blocked by MMD leadership. ${ }^{66}$ If Sata and the PF do not represent a real choice among alternatives for Zambians, this can bring about further apathy with the current democratic order in Zambia, for voters that are dissatisfied by the level of social service policies.

\section{Conclusion}

Conventional scholarship says that multiparty competition can incentivize leadership to provide higher levels of social services, as they become fearful of being voted out of office, for not doing so. However, several in the wave of regimes that adopted multiparty democracy in Africa during the early 1990s kept hold of authoritarian attributes indicative of previous regimes. Regime hybridity usually meant that while citizens could vote for a candidate among many from different parties, the playing field for parties to campaign and win votes was slanted, political repression was still a reality, and few functional checks and balances in the system were institutionalized. These regimes, by their very nature, undermine how we might think democracy should operate. When checks and balances are lost, incentive structures for leadership to be responsive to voters are skewed.

This chapter has thus far attempted to frame the changes and status of social service responsiveness in Zambia within the context of regime change and political evolution in the country.

\footnotetext{
66 "Michael Sata: the Victoria station sweeper turned Zambia presidential hopeful" the Telegraph. 21, September 2011, viewed on: http://www.telegraph.co.uk/news/worldnews/africaandindianocean/ zambia/8777561/Michael-Sata-theVictoria-station-sweeper-turned-Zambia-presidential-hopeful.html
} 
Despite regularly holding multiparty elections since 1991, Zambians continue to be left without an effective channel to voice social service needs to, locally elected leaders are largely incapable of responding to needs, and more capable policy makers lack the incentives to respond to demands in equitable ways. As Zambia backslid from a burgeoning democracy to a clear case of regime hybridity, responsiveness in social service provisions felt the negative impact of a centralizing state and a dominant executive branch. Additionally, multiparty competition did not correlate with the stamping out of systemic corruption or necessarily produce "democratic citizens," both of which are barriers to achieving a "responsive democracy."

Why Zambia has seemingly reached an unresponsive-democracy equilibrium might be a function of democratization in the country. Both domestic and international pressures were important to the decision of the UNIP government to adopt multiparty elections in 1991. In chapter three, I argued that the presence of a domestic democratic movement can help encourage the growth of a more responsive democracy in the post transition period. However Zambia's domestic opposition, post-transition took its seat as the new ruling party, and because internal opposing interests and political parties were not well developed, Zambia's post transition period echoed that of what we expect from an exogenous transition. While a one party dominant systems are certainly not exclusive to exogenously influenced democracies, as I have argued in chapter 3, it is likely to be characteristic of post transition politics in exogenously derived democracies. Indeed, once the MMD took office, an almost 20 year functional oppositional vacuum took hold in Zambia. Lacking a functional opposition in the first decade or so, to balance out the new ruling party and act as a democratic watchdog, certainly enabled the hybridization of the new regime.

International actors, namely Western foreign aid donors, were practically the only actors left that had leverage over the new regime to control their authoritarian slants. Mainly through the threat of, or actual, revoking foreign aid, were Western donors able to reign in the increasingly 
authoritarian Chiluba regime. However, one might imagine that international pressure to become more democratic produces a different democratic result from domestically induced reforms. Donors were essential to achieving the institutionalization of multiparty competition, but were unable to produce a system that linked citizens to politicians in meaningful ways to ultimately produce a responsive democracy. As argued in chapter three, through a donor's perspective, whether a country holds regular multiparty elections is relatively easy to monitor (Uvin 1993), however conditioning foreign aid on the progress a country has in institutionalizing responsive social service delivery is much more difficult, especially when one considers the multiple agendas that donors wish countries to follow. And indeed, donors had multiple agendas in Zambia, namely political and economic liberalization. Thus, when economic reforms seemed to be followed, donors had a difficult time punishing political backsliding. Punishment was usually administered in cases of dramatic threats to democracy, like when the constitution was changed to prevent Kaunda from running against Chiluba in the second election. This produced a democratic boundary for the regime; as long as it stayed within certain confines, which in its basic sense included holding regular multiparty elections, the regime could maintain both its ability to manipulate the political system (including social service resource allocations), as needed, and maintain its international lifeline. Consequentially, the depth of Zambia's democracy suffered.

If exogenously influenced democratic leaders all operate within a foreign defined democratic boundary, without strong incentives to institutionalize responsiveness at home, one wonders if the citizens of exogenously derived democracies experience democracy differently than their endogenously derived democratic counterparts. Do citizens expect less from the democratic system, when it has not effectively resulted in real change in their own lives? Are citizens in exogenously derived democracies less likely to support the system itself, because of the way they have experienced it? In the next chapter, I address these questions by examining whether the exogeneity 
of a transition impacts citizen's satisfaction with democracy and their support for a democratic system. 


\section{Chapter Five: Exogenous Democratization and Bottom-up Democratic Consolidation}

Thus far this dissertation has focused on the impact of exogenous democratization on the quality of life in Africa. The previous chapter established that partly due to the exogeneity of democratization in many countries on the continent, few governments have made strides in responding to their citizen's most basic needs by providing a higher quality of life. This finding provides insight into one dimension of an exogenously derived democracy's depth: its ability to bond citizens with their government. However, the disconnected nature between citizens and elected leaders of unresponsive governments may have several other important implications beyond institutionalizing a reactive government to its citizenry's material needs. These possible implications beg additional questions regarding the impact of exogenous democratization. Of specific interest, how might exogenously derived democratization impact the consolidation of democracy itself? Are these democracies in more danger of reversing back to authoritarianism, thus abandoning gains made in enhanced political rights?

Democracies are generally thought to become "consolidated" once the vast majority of both the elites and general public consider democracy to be a better system of government then its alternatives (Diamond 1999: 65; Lipset 1981: 64; Linz 1978: 16-18; Dahl 1971: 129-131). As discussed in chapter 2 , an extraversion framework inspires a particularly pessimistic view in terms of evaluating how committed elites in an exogenous democracy might be to the democratic experiment. Through this perspective, their attachment to democracy is dependent upon whether its practice continues to be rewarded by foreign patrons. If at some point, democracy proves to be less valuable for leaders to depend on in their extraversion portfolio, support at the elite level may wane. With elite support dependent upon foreign influence, democratic consolidation in many of Africa's new democracies may, at some point, rely more heavily upon the public's commitment to defend the 
democratic experiment. However, if the exogeneity of democratization negatively impacts citizens' satisfaction with and/or support for democracy, further pessimism regarding the sustainability of democracy in many of Africa's new democracies may be warranted, as the public will likely be less willing to fight for its survival.

Given prevalent arguments of the determinants of democratic attitudes in Africa, what, if any, effects exogenous democratization may have on support for and satisfaction with democracy are unclear. On the one hand, citizens of exogenously derived transitions may be more likely to view democracy as an elite project that has little consequence on their lives, and will thus be less satisfied with the state of democracy in their country and have less invested in the system as a whole. Also, by definition, exogenously derived democracies are likely to have weak or nonexistent domestic prodemocracy movements. Thus, citizens in these settings will probably have had fewer opportunities to join or interact with democratic organizing and to be exposed to democracy promotion propaganda, which may have otherwise inspired the growth of a more bottom-up, passionate democratic culture. Conversely, others have argued that support for democracy in Africa is more intrinsic then instrumental; thus we might expect that citizens will have an attachment to democracy as a system which transcends their own experiences (Bratton \& Mattes 2001a), however negatively affected they were by the exogeneity of the transition. Moreover, satisfaction with and support for democracy maybe positively influenced by increases political rights and civil liberties that, theoretically, both exogenous and endogenous democracies experience during a transition (Mattes \& Bratton 2007)

In this chapter, I examine the merits of these competing arguments using survey data from the Afrobarometer. I begin by reviewing the literature on the determinants of satisfaction and support for democracy, and pay particular attention to those arguments that can shed additional insight on to the possible impact of exogenous democratization. After, I discuss the data and 
estimation strategy used, and then move on to discuss the results from several regression analyses. I find that the exogeneity of a transition is negatively associated with some measures of democracy attachment and satisfaction with democracy, however the estimated effect is relatively small.

\section{Support for and Satisfaction with Democracy and Exogenous Democratization}

While volumes have been written on the determinants of public satisfaction and support for democracy in general, less is known about how its drivers may be impacted by the African context (Bratton \& Mattes 2001a; Mattes \& Bratton 2007; Evans \& Rose 2007; Chu et al. 2008; Fails 2009; Bratton, Mattes \& Gyimah-Boadi 2004). In general, "conventional” theories found to be important to explaining attitudes towards democracy in other settings have had mixed success in the African context. Below I review what has been found regarding public support and satisfaction with democracy in Africa and discuss how some findings may further inform expectations of the effect of exogenous democratization on democracy attitudes on the continent.

While modernization theory is often leveraged to understand the transformation of political cultures cross-nationally (Inglehart 2005), its utility in explaining democratic attitudes in Africa has been somewhat mixed. Through a modernization lens, a more democratic-supportive culture emanates from economic transformation of industrialization. Those that stand to benefit from industrialization will be more prone to support democratization, as it is political means to check the power of a potentially economically hazardous authoritarian government, (Lipset 1959; Inglehart \& Welzel 2009; Inglehart \& Baker 2000; Inglehart 1997). The likely the beneficiaries of industrialization are often seen as those with a higher income, more education and those that live in an urban area. Additionally, as Evans and Rose (2007) note of Malawi, but will arguably apply to most countries in Africa, we may also expect that men will support democracy for similar "modernization" rationing, "given that women in Malawi continue to play traditional roles while men have greater spatial and 
occupational mobility, it might be expected that males could benefit more from the modernizing influences of democracy and therefore be more supportive" (911).

However, modernization related explanatory variables have received mixed support in analyses of democratic support and democratic satisfaction in Africa. For example, in the case of education, while Bratton and Mattes (2001b) found that highly educated Afrobarometer respondents were more skeptical about democracy, Bratton, Mattes and Gyimah-Boadi (2005) and Evans and Rose (2007) found that education was positively linked to preferring democracy over alternatives. ${ }^{67}$ Similarly, males and urban residents have been found to be more supportive of democracy than their female and rural counterparts in two of the three analyses that have investigated its role in Africa (Evans \& Rose 2007; Bratton, Mattes \& Gyimah-Boadi 2005); Mattes and Bratton (2007) found no such relationship. Finally, a respondent's income has found the least support in these analyses; the two studies that have investigated its role, Chu et al. (2008) and Mattes and Bratton (2007), have not found a significant relationship. This lack of consistent support for modernization theory's explanatory power on support for democracy in the African context is not necessarily surprising. As discussed in chapter 2, modernization theory's assumptions about the social and political impacts of economic growth are somewhat misplaced in Africa, where spurts of economic growth are less likely to produce an empowered middle class and, in some countries, likely to benefit expatriatedominated enclaves. Thus, those who enjoy social privilege in Africa may have less invested in regime type then what modernization theory would otherwise suppose.

In contrast to modernization, variables that capture the likelihood of a person learning about democracy have been associated more consistently with greater support for democracy as a system in Africa. Specifically, those who have more access to information about democracy (the youth, ${ }^{68}$

\footnotetext{
${ }^{67}$ Evans and Rose (2007) were only examining Malawian respondents.

${ }^{68}$ Younger people are expected to have more access to information via the Internet on democracy, which will help them learn about democracy at home and abroad.
} 
higher educated and those with access to multiple news sources), have some knowledge of who their leaders are, and have interest in political affairs have been found to be more supportive of democracy as a system (Bratton, Mattes \& Gyimah-Boadi 2005: 220; Evans \& Rose 2007; Fails 2009; Mattes \& Bratton 2007). However, these variables have a less clear impact on satisfaction with democracy (Bratton, Mattes \& Gyimah-Boadi 2005: 220; Mattes \& Bratton 2007). To explain this paradox, several have argued that when people politically learn they are more likely to be exposed to pro-democracy information and have the opportunity to critically assess the merits of democracy against its alternatives, and will thus be more supportive of democracy as a system (Nie, Junn \& Stehlik-Barry 1996; Mattes \& Bratton 2007:199). However, a greater awareness of national politics, which results from political learning or political information engagement, could impact satisfaction of democracy in varying ways. On the one hand, citizens may be more critical of the state of democracy in their own country, when they have access to information for how democracy works in more democratic countries. Conversely, more aware citizens may be satisfied with democracy when others are not, because they find satisfaction in the delivery of political goods, where others may still look to other signs, like the state of the economy or the responsiveness of the government in other policies, to shape their opinion about the state of democracy in their country (Bratton, Mattes \& Gyimah-Boadi 2005; Mattes \& Bratton 2007).

Others have hypothesized that certain features common in African cultures will likely inhibit support for democracy. For example, a "parochial rural culture may limit the radius of interpersonal trust to the immediate scope of the village, neighborhood or clan," (Mattes \& Bratton 2007: 196) thus decreasing a more general level of civic cooperation, which is necessary for a more democratic culture to arise (Putnam, Leonardi \& Nanetti 1993). By this reasoning, we may expect that those who live in rural areas and/or have low levels of co-national trust will be less supportive of democracy, generally. Also, at a basic level, support for democracy as a system of governance 
partially relies upon some agreement on the identity of the political community itself (Mattes \& Bratton 2007: 196). If a respondent identifies more with their respective ethnic group, for example, than the nation, she may be relatively apathetic to the type of political system that is institutionalized at the national level, and thus, exhibit less support for democracy. These particular cultural explanations have found little support among studies that have tested for their effects on support for democracy (Bratton, Mattes \& Gyimah-Boadi 2005; Mattes \& Bratton 2007).

A final cultural theory argues that support for democracy somewhat hinges on a person's belief that citizens should be in a position to hold leadership responsible. As Michael Bratton (1992: 93) argues, decades of living under neopatrimonialism and authoritarianism may have bred a passive political culture in many African countries wherein people come to perceive government as a caretaker and do not accept that their role as citizens will be to question or hold leadership accountable. Put differently, a culture of passivity may negatively impact support for democracy as a system, because, in a basic sense, democracy institutionalizes government accountability to the votes of citizens. To this end, both Bratton, Mattes and Gyimah-Boadi (2005) and Mattes and Bratton (2007) found that risk tolerance (interpreted to be the opposite of a passive culture) is positively associated with support for democracy. However, in the same way that a "culture of passivity" was likely formed or reinforced by the political impacts of authoritarianism and neopatrimonialism, democratization may also have a lasting impact on society's political culture. Especially in the cases of more endogenously derived democracies, wherein broad-based domestic democracy movements were influential to the decision to politically liberalize, it is imaginable that some pre-existing passive cultural attitudes will be challenged and replaced with attitudes that demand accountability from government as a result of democratization. ${ }^{69}$

\footnotetext{
${ }^{69}$ However, it may also be true that those countries that had more endogenously derived transitions had a more active political culture to begin with, which would partly explain the rise of a domestic democracy movement in these countries.
} 
Like the "culture of passivity," the debate about the role that government performance might play in shaping support for and satisfaction with democracy highlights the possible impact that the exogeneity of a transition might have on attitudes towards democracy. Specifically, this debate is generally framed in terms of viewing citizens as either valuing democracy intrinsically, or as an end in it and of itself, or instrumentally, as a means to achieve a policy or economic outcome. If a citizen views democracy to be instrumental to raising their own economic standard of living, or that of their nation, their support for and satisfaction with democracy will be related to perceived notions of whether the elected government is having a positive impact on their own or the nation's economic prospects, as well as the government's performance in providing other goods which may raise their standard of living, like social services (Mattes \& Bratton 2001a). Through this perspective, our expectations about cross-national variation in support for democracy can then be directly informed by the findings outlined in chapter three. Specifically, exogenous democratization was found to have a hampering effect on changes in social service delivery. Thus, if citizens hold a more "instrumental" view of democracy, those in exogenously derived democracies may likely be disillusioned with its performance, due to the unresponsive nature of government, as well as less attached to democracy as a system. Instrumental evaluations are somewhat dangerous for the consolidation of democracy more generally; when support for democracy is instrumentally driven, the public will only be as committed to democracy as their opinions of government performance on other policies are favorable.

Conversely, if citizens are more likely to evaluate democracy intrinsically, the lack of responsiveness of exogenous democratization, for example, will be unlikely to impact support or satisfaction with democracy. Instead, support for the system should be independent of any policy performance and satisfaction with democracy in the country will be dependent upon a person's 
evaluation whether the elected government respects the political rights and civil liberties of its citizens, regardless of government performance in other areas (Mattes \& Bratton 2001a).

This important line of inquiry, whether citizens evaluate democracy in mostly intrinsic or instrumental terms, has received considerable attention within the literature on African public opinion, and elsewhere. Bratton and Mattes (2001a) dealt with this issue head on in a paper entitled "Support for Democracy in Africa: Intrinsic or Instrumental?" They reported finding that government performance is indeed important to a person's support of democracy and that approval of the democratic system hinges more on the government's ability to guarantee political rights than economic goods (Bratton and Mattes 2001a). This finding has since received additional empirical support in Mattes and Bratton (2007). ${ }^{70}$ However, regarding the impact of government performance on satisfaction with democracy, Mattes and Bratton (2007) and Bratton, Mattes and Gyimah-Boadi (2005) found that both economic and political performance is associated with higher satisfaction with democracy. These findings underline the high probability that citizens hold multiple views or criteria by which they judge the quality of democracy within their country.

Exogenous democratization may also have a negative impact on democratic attitudes, because those in exogenous democracies will theoretically have less opportunity to engage in a bottom-up democratic civil society. Similar to having access to information and having more cognitive awareness, having an active associational life is also linked to higher support of democracy through the mechanism of "political learning." Specifically, citizens are expected to obtain democratic skills and attitudes when they are members of civil, religious, or political organizations (Putnam, Leonardi and Nanetti 1993), which will make them more supportive of democracy generally. Such membership is also thought to have a positive impact on satisfaction with democracy

\footnotetext{
${ }^{70}$ To some degree, Fails (2009) challenges these findings. He argues that we should look at citizen evaluations of both the substantive and procedural dimensions of political goods and finds that citizens who judge the regime to be more successful in substantive democratization are actually less likely to be committed democrats.
} 
because it helps citizens' feel more "incorporated into the modern democratic polity" (Mattes and Bratton 2007: 196). Moreover, repeated participation in democratic processes or a public movement, which calls for more democracy, may also generate, reflect, or reinforce a stronger sense of support for the system (Lindberg 2006; Finkel, Sabatini and Bevis 2000). With practicing democracy, citizens get to learn more about the processes of how democracy works and will value its outcomes more fully. However, it is important to note that not all participation and social group activity will likely have this effect. Imaginably, participating in an election marred with violence and fraud may produce disillusionment with democracy more generally, and decrease satisfaction with democracy within the country. Finally, other group identification may spur satisfaction with the democratic system for more "realist" reasoning. Supporters of the ruling party, for example, may be more satisfied with democracy because they perceive themselves as likely beneficiaries of the current democratic outcome (Finkel, Sabatini and Bevis 2000). The same may be said for those who identify with the majority ethnic group.

These caveats aside, if democratic civil society engagement does teach lessons about democracy and give people greater appreciation for the democratic system, then we may expect that countries that have a more active civil society will be comparatively more supportive of democracy. In the case of exogenously derived democracies, however, where domestic broad based prodemocracy movements are likely to be weak or non-existent, citizens will likely have had fewer opportunities to join or interact with democratic organizing. Exogenous democratization may not give citizens the same opportunity to engage in pro-democracy civil society, where a certain level of support for the system may be generated.

Possible Negative impact of Exogenous Democratization

Reforms that arise out of an exogenous democratization are the product of negotiations between domestic ruling elites and international actors. While it has been established that the impact 
of democratic reforms on the material lives of citizens in this setting is likely to be limited, an exogenously derived democratization may also have a negative impact on support for and satisfaction with democracy. A truly exogenous democratization is likely to mean little more than a change of the formal rules that the same elites in power previous to the transition play by. Thus, aside of institutionalizing regular elections, exogenous democratization will likely do little to change the relationship between ruling elites and citizens. Politics, thus, is experienced, from the citizen's perspective, without any real and/or substantive tangible change to their daily lives. They will likely feel no further incorporated or empowered politically. Without real transitional implications on the lives of its citizens, exogenous democracies may produce a sense of cynicism regarding what benefit democracy, as a system, is likely to afford, and for the potential of democracy to change things in the future. Additionally, democratization for exogenously derived democracies occurs in spite of a lack of a strong domestic democratic movement. The under-development of a democracy focused, civil society, pre-transition, may carryover post transition. As a result, citizens of exogenously derived democracies may have had less exposure to democracy promotion civil society and would have been given fewer opportunities to learn lessons of the merits of democracy from civil society engagement. To the extent that this type of civil society activity promotes support for democracy, exogenous democratization may be associated with less attachment to democracy.

\section{Data, Variables, and Estimation Strategy}

\section{Afrobarometer}

To examine the possible impact that exogenous democratization has on support for and satisfaction with democracy I turn to data from the fourth round of the Afrobarometer Survey, which was dispersed between March 2008 and June 2009. In addition to being Afrobarometer's most recent round, this round also offers the most country coverage (20 sub-Saharan African 
countries). ${ }^{71}$ Still caution should still be taken when interpreting the results to be representative of the entire region. For example, the Afrobarometer undersamples countries where English is not the official language, non-democracies and those involved in civil war (Mattes and Bratton 2007: 193). Additionally, and more specific to the exogeneity scale developed in chapter 3, the survey oversamples countries that receive a 1 on the exogeneity scale and undersamples countries that score a 0 and 2. Specifically to this point, according to the scale outlined in chapter three, nearly $20 \%$ of sub-Saharan Africa are considered to have endogenously derived regimes, about $25 \%$ of transitions are considered to be influenced significantly by both domestic and foreign influences, and almost $60 \%$ of regimes are thought to exogenously derived. However, in the 20-country Afrobarometer sample, the break down is $10 \%$ endogenously derived, $40 \%$ mixed pressures, and 50\% exogenously derived. ${ }^{72}$ Appendix III includes a break down of the Afrobarometer sample by exogeneity score. The discrepancies between these samples may reveal a skewed sense of what impact exogenous democratization has on attitudes towards democracy. Dependent V ariables: Support for and Satisfaction with Democracy

With these caveats aside, this research does benefit from the range of questions, which gauge attitudes towards democracy that are included on the Afrobarometer. Four measures gauge a respondent's attachment to or support for democracy as a system. Specifically, the first, which I will refer to as prefer democracy, asks the respondent to indicate which of the three following statements come closest to their view: "democracy is preferable to any other kind of government," "in some circumstances, a non-democratic government can be preferable," or “for someone like me, it doesn’t matter what kind of government we have." The other three ask related questions of whether a

\footnotetext{
${ }^{71}$ Benin, Botswana, Burkina Faso, Cape Verde, Ghana, Kenya, Lesotho, Liberia, Madagascar, Malawi, Mali, Mozambique, Namibia, Nigeria, Senegal, Sierra Leone, South Africa, Tanzania, Uganda, Zambia, and Zimbabwe.

${ }^{72}$ In chapter three, Uganda's score was a 0 on the exogeneity scale, because its first multiparty elections were in 2006 , which was outside of the time period examined in chapter three (1990 to 2005). However, this chapter focuses on Afrobarometer data from 2008/2009. Thus, Uganda's exogeneity score was recoded to reflect the fact that it had undergone a transition into multiparty politics. Consistent with the rubric outlined in chapter 3, Uganda's score is a 2 on the scale because the President, Yoweri Museveni remained in power after the first multiparty election.
} 
respondent approves, on a 5 point scale with "strongly disapprove" coded as a 5 , of the following alternative governance systems to a democracy: "only one political party is allowed to stand for election and hold office," "the army comes into govern the country," "elections and parliament/National Assembly are abolished so that the President/Prime Minister can decide everything." Given that these three questions all speak to a similar concept, a factor was generated from the responses to these questions, which I will call, reject alternatives. ${ }^{73}$

Three other questions ask for more specific opinions regarding particular freedoms and procedures associated with democracy and, to a certain extent, allow an assessment of how deep a respondent's attachment is to democracy. Each asks respondents to choose one statement that they agree most with, from a set of two. The first asks about civil society freedom, by giving a choice of the following two statements: "government should be able to ban any organization that goes against its policies," or "we should be able to join any organization, whether or not the government approves of it." The second asks for an opinion on press freedom, with the following two statements: "government should be able to close newspapers that print stories it does not like" or "the news media should be free to publish any story that they see fit without fear of being shut down.” Finally, the last question gauges a person's assessment of the necessity of fair elections, with the following two statements "since elections sometimes produce bad results, we should adopt other methods for choosing this country's leaders" or "we should choose our leaders in this country through regular, open and honest elections." For all three questions respondents are asked to choose from the following responses: (4) agree very strongly with the second statement, (3) agree with second statement, (2) agree with the first statement, or (1) agree very strongly with the first statement (higher values mean agreement with more freedom or the importance of regular elections).

\footnotetext{
${ }^{73}$ Principle components factor analysis extracted a single factor (Eigenvalue $=1.81$ ), which explains $60.2 \%$ of the common variance. The item loadings on the common factor are the following: reject one-man rule $(0.74)$, reject military rule $(0.77)$, and reject one-party rule (0.82).
} 
Another factor was generated based on the responses of two questions that approximated the respondent's satisfaction with democracy within their country. The first of these questions asked respondents how much of a democracy their country was today? Possible responses to this were: (1) not a democracy, (2) a democracy with major problems, (3) a democracy, but with minor problems or (4) a full democracy. The second question asked "overall, how satisfied are you with the way democracy works in [your country]? Possible responses to this question included (0) my country is not a democracy, (1) not at all satisfied, (2) not very satisfied, (3) fairly satisfied, and (4) very satisfied. The factor generated based on the responses from these two questions will be referred to as

\section{democracy satisfaction. ${ }^{74}$}

\section{Multilevel Modeling}

The estimation strategy used to examine the influence of exogenous democratization on attitudes towards democracy had to take into account the fact that the variables of interest are measured at multiple levels. To this end, random effects generalized least squares regression models were used that grouped data by country for most models. However, in the case of democracy preference, the responses to the question are not ordered, thus a multinomial logit was more appropriate to use to examine the effects of the exogeneity of democracy on the various responses to that question. In this model, instead of clustering the data by country, country dummies were included as additional control variables.

\section{Controls Used in Support for Democracy}

Several variables were included in the regression models to control for the possible influences of other mitigating factors. The specific information on the measurements used to approximate these control variables, like the survey question wording and, when applicable, details

\footnotetext{
${ }^{74}$ Principle components factor analysis extracted a single factor (Eigenvalue $=1.52$ ), which explains $76.1 \%$ of the common variance. The item loadings on the common factor are the following: opinion of democracy (0.87), and satisfaction with democracy (0.87).
} 
on the construction of factor variables are included in appendix IV. In general, the controls used replicate or come as close as possible to the controls used Mattes and Bratton's (2007) research which nearly exhaustively examined the determinants of support for and satisfaction with democracy in Africa. Finally, because the hypotheses underlining most of the control variables' effects on support for and satisfaction with democracy were discussed in the literature review, I only briefly summarize the rationale here.

In models predicting support for democracy, gender, education, urbanity, and a rating of the respondent's own living/economic conditions were controlled for to approximate the demographics that modernization theory predicts will be important for the support of democracy. Several variables were also included to capture the "learning" hypotheses, which argues that people with greater access to, or are more likely to seek out, information on politics are likely to learn more of the merits of democracy and thus, support it at a higher rate. To this end, I included a measure of the respondent's access to news, knowledge of their leadership, and interest in national politics. Additionally, I include a measure of how many years the respondent has lived under democratic rule since they turned eighteen. This specific measurement approximates a "life-time learning" hypothesis that argues that adults constantly gather new information, and evaluate lessons about political regimes based on their accumulative experience in living under them (Achen 1992; Rose, Mishler \& Haerpfer 1998). "If true, regime preferences and evaluations should differ not by generation, but according to cumulative individual experience with a range of differing regimes," (Mattes \& Bratton 2007:198). For a similar reason, I also controlled for measures that approximate the extent of a respondent's associational life; respondents may also learn about the merits of democracy from their activity with civil society organization, are also expected to obtain democratic skills and attitudes when they are members of religious, civil, or political organizations (Putnam, Leonardi and Nanetti 1993). Thus, measures approximating membership in civil society 
organizations and the proclivity of a respondent to be active in political organizing were controlled for. In a similar vein, whether the respondent identifies closely with any political party was controlled for to capture another dimension of their involvement in national political civil society.

Both retrospective and prospective, micro and macro evaluations of the economy, as well as the respondent's opinion of the government's handling of economic policies, were controlled for to account for the hypothesis that respondents may displace their (dis)satisfaction with the economy on to their evaluations of the country's democratic experiment. Evaluations of political goods were included for similar reasoning. Specifically, a measure of perceived government corruption, an opinion as to whether their respective ethnic group is treated fairly and trust in leadership were controlled for to account for the possibility that ill feelings towards elites/government might be transposed onto democracy, more broadly. Also, the perceived quality of other political goods like the insurance of freedoms and general responsiveness, (i.e. performance evaluations on the delivery of several social service policies) were controlled for to, again, account for a different dimension of the hypothesis that people displace judgments of how democracy is experienced in their country to their broader evaluation of democracy as a system. Finally, I include controls for ruling party affiliation and identification with the majority ethnic group in a country to account for those that might support democracy because they view themselves as having disproportionate benefits from the current political system.

Finally, cultural hypotheses discussed in the literature review were also controlled for. Those that identify with the nation, rather than an ethnic group, might have more concrete opinions about the political system at a national level and so a control variable is included which approximates identification. A measure of co-national trust is included under the idea that those who distrust conationals may not want to support a political scheme like democracy, where cooperation with conationals is necessary. Finally, a "passive" sense of citizenship is controlled for; those that are 
uncomfortable with seeing themselves in a role of holding leadership accountable may have less support for democracy.

\section{Controls Used in Satisfaction with Democracy}

In several cases, the hypothesis of how a variable might impact support for democracy also extends to its possible impact on satisfaction with democracy; so several of the same variables used in support for democracy models are also used in the model predicting satisfaction with democracy. For example, evaluations of the economy, government responsiveness, quality of leadership (trust in leadership and perceptions of government corruption), and whether the respondent thought their respective ethnic group was treated fairly, were also included in the model predicting satisfaction with democracy to account for the possibility that a respondent's satisfaction with policy performance or the ruling elites will convert into satisfaction with their country's democracy. Similarly, measures of identification with the ruling party or majority ethnic group were also controlled for to account for the possibility that these respondents will be more satisfied with how democracy works in their favor.

Modernization type demographics, like wealth, education, urbanization, and gender, and variables that approximate the likelihood for a respondent to form opinions from lessons learned about national politics, like access to news, knowledge of leaders, interest in politics, and years lived past the age of eighteen in a democracy, were included for slightly different reasoning then the rationale that underlined their inclusion in support for democracy models. Both sets of hypotheses highlight those that will likely support democracy because of what it represents as a system. In the case of modernization theory, likely support will come from those that value the idea that democracy decentralizes political power, giving the capitalist class more of a chance to hold leadership accountable. However, it is less clear what this possible relationship implies for satisfaction with democracy. In the case of a "hybrid" regime, for example, it may be the case that those who are 
likely to pull for broader democratization will be satisfied with democracy in their country because it has become more democratic then it was in the past. Conversely, they may be less satisfied with democracy because they feel that the country's democracy has not yet reached its potential.

In the case of "learning" theorists, they argue that the more people learn about politics, the more they will value the intrinsic freedoms democracy affords. However, it is less clear what role these variables will play on satisfaction. Political knowledge may increase satisfaction with democracy, when a country is becoming more democratic then it used to be. However, those that learn about politics in their country or are more cognitively developed, are more likely to also have access to information which will be critical of the quality of democracy in their country, which could induce dissatisfaction. Also, they will be assumingly more saturated in information about the how democracy operates, elsewhere, in more democratic countries, which may induce a "comparative" dissatisfaction. This is similarly the case with measures, which capture the extent of a respondent's civil society activity. To the extent that civil society activity educates a person on the nature of politics in a country, this activity could impact satisfaction both negatively or positively.

Unlike models that approximate support for democracy, I did not control for cultural variables. I could not think of any reason why the cultural type variables, like national identification, co-national trust, and passive citizenship would impact satisfaction with democracy. I also did not control for the evaluation of the state of specific political freedoms in their country (like freedom of speech and free elections), because it would closely approximate the dependent variable: satisfaction with democracy.

\section{Results}

The results of the support of democracy models are displayed in tables 1 and 2. Specifically, in table 1, I display the results of a multinomial logit model predicting responses to the prefer 
democracy question. While, I display GLS regression models predicting the rejection of alternatives factor, and responses to the civil society freedom, press freedom and the necessity of fair elections questions in table 2. While these models all relate to attachment to democracy generally, or specific elements of democracy, they all focus on a different dimension of attachment to democracy. In the first table a more general question about preferring democracy is asked, while the second table displays the results from more specific questions asked. These more pointed questions help to paint a more robust look at how citizens are affected by the exogeneity of a transition. Finding a consistent associated effect of the exogeneity of a transition, or any other variable, across these models should increase confidence that such a relationship indeed exists.

Table 1 displays the results of the multinomial logit regression for the "prefer democracy" dependent variable. As mentioned previously, country dummy variables were also included in this model to account for national specific variations, however their effects are unreported. The baseline in this case is statement two: "in some circumstances, a non-democratic government can be preferable." In column one, is the influence of the control variables on the chance that someone would choose, the first statement: "democracy is preferable to any other kind of government", over the baseline. In the second column, is the estimated effects of the control variables on the chance that someone would choose the third statement: “for someone like me, it doesn't matter what kind of government we have" over the baseline The results indicate that the exogeneity of a transition is actually positively and significantly related to a respondent agreeing with "democracy is preferable to any other kind of government" over "a non-democratic government can be preferable. In the second column, the results indicate that the effect of an exogenous transition on being apathetic to the regime type is not significant.

While the second finding is not necessarily unexpected, finding a positive effect on exogenously derived democratic citizens preferring democracy is interesting and somewhat 
unexpected. However, caution should be taken with putting much value in this finding. This question is quite broad and asks a general question about preferences about democracy, in the abstract. Others have noted that such questions may lead researchers down blind alleys (Canache, Mondak and Seligson 2001). People have various definitions about what democracy is, and thus broad questions about the concept may result in incomparable responses. This might be most expected in exogenous democratization; if citizens in these settings do feel particularly distant from the political system of their country, their views about what democracy is may be highly variable. Thus, it is important to examine what effect exogenous democratization has on more specific questions about elements of liberal democracy, to understand if this finding is robust or if it is, indeed, a blind alley. This is addressed in table 2. 
Table 1: Multinomial Logit, Prefer Democracy

\begin{tabular}{|c|c|c|c|c|}
\hline \multirow[b]{2}{*}{ Variables } & \multicolumn{2}{|c|}{$\begin{array}{l}\text { Choosing Statement } 1 \\
\text { (Prefer Democracy) }\end{array}$} & \multicolumn{2}{|c|}{$\begin{array}{l}\text { Choosing Statement } 3 \\
\text { (No Preference) }\end{array}$} \\
\hline & Coef. & Std. Err. & Coef. & Std. Err. \\
\hline Exog & $0.75^{* *}$ & 0.35 & 0.32 & 0.28 \\
\hline Living Conditions. & 0.02 & 0.04 & $-.07 * *$ & 0.03 \\
\hline Education & 0.03 & 0.03 & $0.07 * * *$ & 0.02 \\
\hline Urban & -0.07 & 0.10 & 0.07 & 0.07 \\
\hline Male & 0.02 & 0.09 & $0.14^{* *}$ & 0.06 \\
\hline Age in democracy & -0.01 & 0.01 & 0.01 & 0.01 \\
\hline Access to News & -0.02 & 0.05 & 0.01 & 0.04 \\
\hline Political Knowledge & 0.01 & 0.05 & $0.12^{* * *}$ & 0.04 \\
\hline Political Interest & -0.02 & 0.06 & $0.14 * * *$ & 0.05 \\
\hline Active Civil Society & $0.11 * *$ & 0.05 & $0.12^{* * *}$ & 0.04 \\
\hline Member society & $-0.10^{* *}$ & 0.05 & $-0.13^{* * *}$ & 0.04 \\
\hline Partisanship & $-0.36^{* * *}$ & 0.09 & 0.08 & 0.07 \\
\hline Economic policy eval & $0.16^{* * *}$ & 0.06 & $-0.20 * * *$ & 0.04 \\
\hline Pros. Ec. Eva. & 0.02 & 0.05 & 0.01 & 0.04 \\
\hline Retro ec eval & $-0.08^{*}$ & 0.04 & 0.01 & 0.04 \\
\hline Corrupt & $-0.11 * *$ & 0.05 & $-0.17 * * *$ & 0.04 \\
\hline Trust leadership & 0.01 & 0.05 & $0.07 *$ & 0.04 \\
\hline Ethnic & -0.05 & 0.05 & $-0.07 * *$ & 0.03 \\
\hline Gov perf & 0.09 & 0.06 & -0.06 & 0.04 \\
\hline Free speech & $0.09 *$ & 0.04 & $0.21 * * *$ & 0.03 \\
\hline Free elect & $0.08^{*}$ & 0.04 & $0.19 * * *$ & 0.03 \\
\hline Ruling Party & 0.16 & 0.10 & 0.12 & 0.08 \\
\hline Majority ethnic & -0.06 & 0.01 & 0.05 & 0.07 \\
\hline Nat id & $-0.10 * * *$ & 0.04 & $0.05^{*}$ & 0.03 \\
\hline Passive factor & 0.04 & 0.04 & $-0.06^{*}$ & 0.03 \\
\hline Trust & -0.06 & 0.05 & -0.02 & 0.03 \\
\hline Constant & -0.16 & 0.64 & 0.45 & 0.49 \\
\hline \multicolumn{2}{|c|}{ Log likelihood } & -6811.67 & & \\
\hline Prob> chi2: & 0.00 & Pseudo R2: & 0.08 & 10783 \\
\hline
\end{tabular}

*** $\mathrm{p}<0.01$ (two-tailed), ${ }^{* *} \mathrm{p}<0.05$ (two-tailed), ${ }^{*} \mathrm{p}<0.1$ (two-tailed) 
Table 2: Exogenous Democratization and Attachment to Democracy

\begin{tabular}{|c|c|c|c|c|c|c|c|c|}
\hline \multirow[b]{2}{*}{ Variables } & \multicolumn{2}{|c|}{ Reject Alts. } & \multicolumn{2}{|c|}{$\begin{array}{l}\text { Civil Society } \\
\text { Freedom }\end{array}$} & \multicolumn{2}{|c|}{ Press Freedom } & \multicolumn{2}{|c|}{ Prefer Elections } \\
\hline & Coef. & Std. Err. & Coef. & Std. Err. & Coef. & Std. Err. & Coef. & $\begin{array}{l}\text { Std. } \\
\text { Err. }\end{array}$ \\
\hline Exogeneity & $-0.05^{* * *}$ & 0.02 & $-0.06^{* * *}$ & 0.02 & $-0.05^{* * *}$ & 0.02 & -0.02 & 0.02 \\
\hline Living Sit. & $-0.03^{* * *}$ & 0.01 & $-0.03 * * *$ & 0.01 & -0.00 & 0.01 & 0.01 & 0.01 \\
\hline Education & $0.04 * * *$ & 0.01 & $-0.02 * * *$ & 0.00 & $0.01 *$ & 0.01 & 0.01 & 0.01 \\
\hline Urban & $0.04 * *$ & 0.02 & 0.02 & 0.02 & $0.06 * * *$ & 0.02 & $0.07 * * *$ & 0.02 \\
\hline Male & $0.03^{*}$ & 0.02 & -0.02 & 0.02 & $0.06^{* * *}$ & 0.02 & 0.02 & 0.02 \\
\hline Age in Democ & 0.00 & 0.00 & -0.00 & 0.00 & $-0.00 * * *$ & -0.00 & -0.00 & 0.00 \\
\hline Access to News & $0.02^{* *}$ & 0.01 & $0.03^{* * *}$ & 0.01 & $0.02 *$ & 0.01 & $-0.02^{* *}$ & 0.01 \\
\hline Political Knowledge & $0.12^{* * *}$ & 0.01 & $0.03 * * *$ & 0.01 & $0.04 * * *$ & 0.01 & $0.05^{* * *}$ & 0.01 \\
\hline Political Interest & $0.04 * * *$ & 0.01 & $0.05^{* * *}$ & 0.02 & $0.02 *$ & 0.01 & $0.05^{* * *}$ & 0.01 \\
\hline Active Civil Society & $0.06^{* * *}$ & 0.01 & $0.04 * * *$ & 0.01 & $0.03 * *$ & 0.01 & -0.01 & 0.01 \\
\hline Assoc. Member & $-0.02 * *$ & 0.01 & $-0.06^{* * *}$ & 0.01 & $-0.02 * *$ & 0.01 & $0.03 * * *$ & 0.01 \\
\hline Partisanship & 0.02 & 0.02 & 0.04 & 0.02 & -0.02 & 0.02 & $0.06^{* * *}$ & 0.02 \\
\hline Economic policy eval. & $-0.10 * * *$ & 0.01 & -0.01 & 0.01 & $-0.07 * * *$ & 0.01 & $-0.07 * * *$ & 0.01 \\
\hline Pros. Econ. Eval. & -0.01 & 0.01 & 0.01 & 0.01 & $0.05^{* * *}$ & 0.01 & $0.05^{* * *}$ & 0.01 \\
\hline Retro. Econ. Eval. & 0.00 & 0.01 & $0.03 * * *$ & 0.01 & $0.02 * *$ & 0.01 & $0.03^{* * *}$ & 0.01 \\
\hline Corrupt Gov’t & 0.01 & 0.01 & 0.02 & 0.01 & $0.03 * * *$ & 0.01 & -0.01 & 0.01 \\
\hline Trust in Leadership & $-0.04 * * *$ & 0.01 & $-0.03 * * *$ & 0.01 & $-0.04 * * *$ & 0.01 & $0.04 * * *$ & 0.01 \\
\hline Ethnic Fair Treatment & $-0.05 * * *$ & 0.01 & $-0.04 * * *$ & 0.01 & $-0.04 * * *$ & 0.01 & $-0.04 * * *$ & 0.01 \\
\hline Gov't Resp. & -0.02 & 0.01 & $-0.04 * * *$ & 0.01 & -0.02 & 0.01 & $0.02 *$ & 0.01 \\
\hline Free Speech & $0.07 * * *$ & 0.01 & 0.01 & 0.01 & 0.01 & 0.01 & $0.07 * * *$ & 0.01 \\
\hline Free Elections & 0.00 & 0.01 & 0.02 & 0.01 & $-0.04 * * *$ & 0.01 & 0.01 & 0.01 \\
\hline Ruling Party & $-0.18^{* * *}$ & 0.02 & $0.10^{* * *}$ & 0.02 & $-0.08 * * *$ & 0.02 & $-0.06^{* *}$ & 0.02 \\
\hline Majority Ethnic & $-0.07 * * *$ & 0.02 & $0.10^{* * *}$ & 0.02 & $0.04 *$ & 0.02 & $-0.12^{* * *}$ & 0.02 \\
\hline National ID & $-0.02 * *$ & 0.01 & $-0.02 * *$ & 0.01 & -0.00 & 0.01 & 0.01 & 0.01 \\
\hline Passive Culture & $-0.10^{* * *}$ & 0.01 & $-0.15^{* * *}$ & 0.01 & $-0.08^{* * *}$ & 0.01 & $-0.05^{* * *}$ & 0.01 \\
\hline Trust Co-Nationals & $0.03^{* * *}$ & 0.01 & $0.03 * * *$ & 0.01 & $0.03 * * *$ & 0.01 & 0.02 & 0.01 \\
\hline Constant & $-0.16^{* *}$ & 0.07 & $3.05^{* * *}$ & 0.08 & $3.31 * * *$ & 0.07 & $2.79 * * *$ & 0.08 \\
\hline Prob>chi ${ }^{2}:$ & \multicolumn{2}{|c|}{0.00} & \multicolumn{2}{|c|}{0.00} & \multicolumn{2}{|c|}{0.00} & \multicolumn{2}{|c|}{0.00} \\
\hline overall: & \multicolumn{2}{|c|}{0.10} & \multicolumn{2}{|c|}{0.04} & \multicolumn{2}{|c|}{0.05} & \multicolumn{2}{|c|}{0.03} \\
\hline between: & \multirow{2}{*}{\multicolumn{2}{|c|}{$\begin{array}{l}0.57 \\
0.07\end{array}$}} & \multirow{2}{*}{\multicolumn{2}{|c|}{$\begin{array}{l}0.28 \\
0.03\end{array}$}} & \multirow{2}{*}{\multicolumn{2}{|c|}{$\begin{array}{l}0.19 \\
0.04\end{array}$}} & \multicolumn{2}{|c|}{0.26} \\
\hline within: & & & & & & & \multicolumn{2}{|c|}{0.02} \\
\hline $\mathrm{N}$ & \multicolumn{2}{|c|}{10838} & \multicolumn{2}{|c|}{10780} & \multicolumn{2}{|c|}{10857} & 109 & \\
\hline
\end{tabular}

In contrast to table 1, table 2 reveals that the exogeneity of a transition has a negative and significant effect on the proclivity of a respondent to reject alternative regime types to democracy, a respondent's view of whether the citizens should be able to join any civil society organization and whether the news media should be free to publish any story that they see fit without fear of being 
shut down. This set of results paints an almost robust picture that the exogeneity of a transition may indeed have a negative effect on attachment to democracy and, possibly, helps to illustrate the weakness of the findings of table 1, which were based on a more general and abstract concept of democracy. However the negative effects found, in table two, prove to be quite modest. Specifically, moving from the minimum level of exogeneity (0) to the maximum (2), results in about a 0.10 decrease on the reject alternatives factor variable, which has a range from -3.44 to 0.98 . Similarly the same shift from minimum to the maximum level of exogeneity, results in about a 0.10 to 0.12 decrease on the four point scales of a person's proclivity to view free organization and free press as important for the country. However the same shift from a minimum to a maximum value of the passive culture measure results in much larger estimated impacts. Specifically, the shift from minimum to maximum of passive cultural attitudes results in a 0.37 decrease in the proclivity of a person to reject democracies alternatives, 0.55 decrease in a person's view of free organization as being important, and a 0.30 decrease in a person's view of free press being important. This comparison highlights the relatively small estimated effect that the exogeneity of a transition has on support for democracy. Finally, the exogeneity of the transition's negative impact on whether a person thinks that fair and honest elections should be used to select the country's leadership is not statistically significant.

Putting aside considerations regarding the size of the effects, these results beg the question: why might an exogenous transition negatively impact attachment to democracy more generally and feelings about free organization and media, but not elections? At the bare minimum, exogenous transitions still involve the establishment of multiparty elections, while other institutions or cultural attitudes towards government may remain unchanged. Thus, citizens of both exogenously and endogenously derived transitions both experience the practice of elections, and thus any effect of an exogenously derived transition may be muted when it comes to impacting opinions on elections. 
The results in table 1 also support and challenge some of the other theories regarding the determinants of attachment to democracy. For example the political learning hypotheses are consistently reaffirmed through these analyses, as all variables associated with political knowledge/learning (access to news, political knowledge and political interest) are significantly and positively related to attachment to democracy, across all models. All other groups of variables, in contrast, do not have consistent effects across the models nor are their significant effects consistent with theoretical expectations. For example with modernization type variables, a person's quality of living situation, a proxy used for wealth, is unexpectedly negatively related to attachment to democracy. Puzzlingly, education's effects are found to be both positive and negatively influential to attachment to democracy. In the cases of gender and urban dwelling, however, when significant, they are as expected, positively related to attachment to democracy.

Similarly, when the effects of civil society involvement, as measured through whether someone engages in various civil society activities (active civil society), are found significantly related they are so in the expected positive direction. However, membership in civil society groups has a negative impact on attachment to democracy in three out of four models and partisanship has no effect at all in three out of four models. The impact of evaluations on the economy and economic policy also has mixed effects across variables and models. This is also the case with the impact of a person's evaluation of political goods provided by the government. Trust in leadership, when significantly related is mostly also negatively related to attachment to democracy. This might reflect a person's willingness to bend the democratic rules to retain the leaders they trust. A similar sentiment might make sense of the consistent and negative effect of feeling like a person's ethnicity is treated fairly on attachment to democracy; one may be willing to compromise democracy if it means their particular ethnic group will be treated fairly under an undemocratic system. Ruling party attachment and membership in a majority ethnic group have significant but mixed effects across models. 
Cultural variables have mixed success, as well. On the one hand, as discussed above, an expressed passivity is consistently and negatively associated with attachment to democracy. Similarly, expressed trust in co-nationals is found to impact support for democracy in the expected direction, when significant. In contrast, national identification, when significant, is unexpectedly found to have a negative impact on attachment to democracy. Finally and surprisingly, a person's evaluation of whether the government has performed well in providing social services (government responsiveness) does not have a consistent or positive effect on attachment to democracy.

To summarize the exogeneity of a transition has had a 'mixed' record with regard to its possible effect on attachment to democracy. On the one hand it is negatively associated with rejecting democracy's regime alternatives, and support for the ideas that the press should be free and that people should freely organize. While the exogeneity of a transition's estimated negative effects on attachment are relatively small, finding a negative association confirmed the hypotheses that exogenous democratization may undermine the consolidation of democracy more generally. Conversely, though, exogenous democratization was also found to positively impact a person's preferences with democracy and it was found to have no significant effect on support for free elections. Next I turn to examining the effect that the exogeneity of democracy has on satisfaction with democracy.

Table 3 displays the results of the GLS regression model used to predict satisfaction with democracy within the respondents' country. Exogeneity is found to be negatively associated with satisfaction with democracy, but like the negative effects found with attachment, the size of the effect seems relatively small. In this case, moving from the minimum level of exogeneity $(0)$ to the maximum (2), results in a 0.06-point decrease in satisfaction with democracy, which is a factor variable with a range of -2.49 to 1.50 . However, moving from a non-ruling party supporter to a 
ruling party supporter results in a 0.16 -point increase in satisfaction, which is more than double that of the effect of exogeneity.

Table 3: Exogenous Democratization and Satisfaction with Democracy

\begin{tabular}{|c|c|c|c|}
\hline & & \multicolumn{2}{|c|}{ Democratic Satisfaction } \\
\hline & & Coef. & Std. Err. \\
\hline \multicolumn{2}{|c|}{ Exogeneity } & $-0.03 * *$ & 0.01 \\
\hline \multicolumn{2}{|c|}{ Living cond } & $0.03^{* * *}$ & 0.01 \\
\hline \multicolumn{2}{|c|}{ Education } & $-0.06^{* * *}$ & 0.00 \\
\hline \multicolumn{2}{|c|}{ Urban } & 0.01 & 0.02 \\
\hline \multicolumn{2}{|c|}{ Male } & $-0.03^{*}$ & 0.02 \\
\hline \multicolumn{2}{|c|}{ Democ Live } & 0.00 & 0.00 \\
\hline \multicolumn{2}{|c|}{ Access to News } & 0.01 & 0.01 \\
\hline \multicolumn{2}{|c|}{ Political knowledge } & $0.06^{* * *}$ & 0.01 \\
\hline \multicolumn{2}{|c|}{ Political Interest } & -0.01 & 0.01 \\
\hline \multicolumn{2}{|c|}{ Active society } & -0.01 & 0.01 \\
\hline \multicolumn{2}{|c|}{ Civil Society } & $0.03 * * *$ & 0.01 \\
\hline \multicolumn{2}{|c|}{ Partisanship } & $0.10^{* * *}$ & 0.02 \\
\hline \multicolumn{2}{|c|}{ Econ perf. } & $0.07 * * *$ & 0.01 \\
\hline \multicolumn{2}{|c|}{ Pros econ eval } & $0.05^{* * *}$ & 0.01 \\
\hline \multicolumn{2}{|c|}{ Retro econ eval } & $0.03 * * *$ & 0.01 \\
\hline \multicolumn{2}{|c|}{ Corrupt gov't } & $-0.11 * * *$ & 0.01 \\
\hline \multicolumn{2}{|c|}{ Trust leadership } & $0.30 * * *$ & 0.01 \\
\hline \multicolumn{2}{|c|}{ Ethnic fair treat } & $-0.10 * * *$ & 0.01 \\
\hline \multicolumn{2}{|c|}{ Gov responsive } & $0.08^{* * *}$ & 0.01 \\
\hline \multicolumn{2}{|c|}{ Ruling party } & $0.16^{* * *}$ & 0.02 \\
\hline \multicolumn{2}{|c|}{ Majority ethnic } & $-0.06^{* * *}$ & 0.00 \\
\hline & $\begin{array}{l}\text { Overall: } 0.27 \\
\text { Within: } 0.21 \\
\text { Between: } 0.50\end{array}$ & $\begin{array}{l}\text { Prob>chi } 2: \\
0.00\end{array}$ & $\mathrm{~N}: 11591$ \\
\hline
\end{tabular}

The other control variables included in this model have, in many cases, very different effects on satisfaction with democracy than they had on attachment to democracy. For example, all modernization type variables have the opposite effect in this model then what they had in table 1. Higher quality living condition is associated with more satisfaction, higher levels of education and being a male, however, is associated with dissatisfaction. With the exception of political knowledge, 
political learning variables are not associated with satisfaction with democracy. Civil society involvement is found to be positively associated with satisfaction. Similarly, all variables approximating economic evaluations are positively associated with democracy. This indicates that people color their views on the quality of democracy with their views about the economy and economic policies. As expected, people are more likely to be satisfied with their democracy when they trust their leadership, are a ruling party supporter, and feel that their government is not corrupt. However, unexpectedly a person's view of whether their ethnic group is treated fairly and membership with the majority ethnic group is negatively associated with satisfaction with democracy.

\section{Conclusion}

The above analyses paint a nuanced, if not complicated, picture of exogenous democratization's effect on attachment to and satisfaction with democracy. I find that the exogeneity of a transition's impact on attachment to democracy is mixed. In three out of the five related analyses, exogenous democratization was found to have a negative relationship on support for various measurements of democracy, but the effect has been relatively small. When asked if a respondent prefers democracy, the exogeneity of a transition has a positive effect, which somewhat contradicts the story told by the previously mentioned models. However, the findings of this table might be less trusted, as they probe responses to a more general question of democracy preferences, which are notoriously unreliably and incomparable. Additionally, with regard to the attachment to free and fair elections, I do not find a significant effect of exogeneity. This, particular null finding, might be understood in light of the fact that citizens of exogenously derived democracies, at minimum, share the experience of elections in common with those of endogenously derived democracies; thus, their attachment to elections may not be significantly different. Finally, I also find 
that exogenous democratization is negatively related to satisfaction with democracy, however the effect is again estimated to be relatively small. ${ }^{75}$

Given these results and the importance of this inquiry, it is clear that these relationships, as well as a deeper examination into the mechanisms that may explain how exogenous democratization may impact attitudes towards democracy, deserve further attention. This chapter started with the unstated assumption that the unintended consequences of foreign led democracy promotion are likely to be reflected in how people view their country's democratic experiment. This dissertation has thus far argued that in exogenous democracies multipartyism was adopted by elites for a, largely, instrumental purpose of appealing to international actors. Due to the end of the Cold War and a reassessment of Western foreign development strategies, multipartyism became a commodity in high demand from international donors in the post-Cold War era. However, there is no guarantee that something else, exogenous to Africa, may change to influence the incentives of its leadership away from multipartyism. For example, something may reduce the value that Western donors put on multipartyism when they consider what governments they will fund and punish. Without these incentives, the leadership of the most exogenously derived democracies may find it in their own interest to undermine the democratic concessions they made in the past, however limited or shallow they may have been. Thus it may be the case that the future of the democratic experiment in Africa's exogenous democracies will one day rely on how willing the broader public is to defend it. If there are negative impacts of exogenous democratizations on people's attachment to and satisfaction with democracy, the consolidation of a more liberalized polity in much of the continent may be in jeopardy.

\footnotetext{
${ }^{75}$ I explored whether the small estimated effects were the product of misspecified mediating relationships between exogenous democratization and passive cultural attitudes, active civil society involvement and government responsiveness, using the analyses outlined in (James \& Brett 1984). I did not find evidence that any of these three variables were substantially mediating the effects of the exogeneity of a transition on democracy attitudes.
} 


\section{Conclusion: Africa's Unresponsive Consolidation or a Way Forward?}

When foreign actors and external events serve as the primary source of influence for a government to adopt multiparty elections it is highly probable that the responsive nature and substance of any ensuing electoral democracy will suffer. Thus, any impact a transition towards multiparyism is expected to have on the quality of life in Africa should be understood within the context of the variation of its origins. When derived endogenously, democratization is associated with enhanced social service delivery and increases in the general quality of life. In other words, democracy likely operates as it is expected to, giving elected officials political incentives to respond to the needs of their broader constituencies (Deacon 2003; Lake and Baum 2001; Bueno de Mesquita et al. 2003; Ghobarah, Huth and Russett 2004; Meltzer and Richard 1981).

However, when the pressure to adopt democratic reforms comes primarily from foreign sources, those reforms, however substantial they may be in other respects, have done little to bring Africans responsive governments. Indeed it is not the case that exogenous democratization has a negative impact on social service delivery or that it deteriorates responsiveness; instead this dissertation has illustrated that it likely has no effect at all. Instead of needing to respond to new institutional incentives, the underlying political game in these settings is characterized by its ability to maintain continuities with the past. Despite a renegotiation of formal rules and institutions, the detached relationship between citizen and policy maker persists, and the link that is expected to bind policy making to the expressed needs of citizens is not formed. Instead, the political playing field at home is likely to remain imbalanced and the ineptness of the opposition to hold a ruling party in check or act as a viable political alternative for voters will remain significantly unchanged.

African regimes have been categorized in this dissertation along a rubric, which is meant to approximate the relative importance of foreign and domestic actors in the decision to adopt 
multiparty elections. The empirical results in chapter 3, based on the effect of the interaction of this "exogeneity of a transition" measure with the degree to which a regime has politically liberalized on quality of life indicators, support my hypotheses. Endogenous democratization is associated with positive changes in social services, while exogenous democratization is not. Over the past two decades, leaders of exogenously derived democracies have failed to respond to Africa's most basic health and education needs.

In addition to documenting the absence of democratization's effect on social service delivery, I have also explored exogenous democratization's possible negative impacts on other important elements of a polity. Exploring the role that exogenous actors played in Zambia's democratic evolution, for example, illustrated several likely unintended consequences of foreign democracy promotion efforts. Within that case I found that donors played a role in giving exogenously derived democracies relatively weak democratic boundaries within which to operate and that ruling elites test those boundaries towards authoritarianism when it is politically necessary for them to secure domestic power. This particular lesson from Zambia's case helps to highlight the role that foreign actors have had in the consolidation of hybridity in so many of the exogenously influenced transition countries.

Also, I found that elites in these settings have the ability to undermine the progress of responsive-inducing reforms, like decentralization, and often have the political incentives to do so as well. Reforms which are aimed at increasing government responsiveness often require ruling elites to relinquish central control over development finance, accept checks on the central government's/executive's power, and/or defend a free and fair democratic playing ground. Domestic and endogenously derived political will to do fulfill any of these requirements is necessary, but desperately hard to come by in an exogenously derived democratic setting. 
Finally, also explored in this dissertation was whether exogenously derived democracy might have a negative impact on public attachment to and satisfaction with democracy, both of which are considered prerequisites to a democratic system's consolidation. Especially in an exogenously derived democracy, where elite support of democracy is assumingly somewhat dependent upon foreign influence, democratic consolidation may at some point have to rely more heavily upon the public's commitment to defend the democratic experiment. I ultimately find some support for the idea that exogenously derived democratization negatively impacts attachment to and satisfaction with democracy.

While the negative effect of exogenous democratization on attachment to democracy found was estimated to be modest, it is still arguably alarming. If support for democracy wanes as a result of exogenous democratization, foreign democracy promoters may be undermining their own efforts to induce eventual domestic ownership and the sustainability of democracy. The gravity of this possibility demands that research on this possible negative externality of exogenous democratization be further pursued. Related future research should focus on parsing out the underlying mechanisms that cause exogenous democratization to decrease attachment to democracy, as different drivers would require different policy responses.

If citizens in this environment are less supportive of democracy because they have had less interaction with domestic democratic civil society, and thus, fewer opportunities learn about and gain an appreciation for the democratic system, interested donors or domestic groups, can respond and maybe counteract this effect by increasing their activity in democratic awareness and education campaigns. However, exogenous democratization may negatively impact attachment to democracy in other ways. Frustrated with the lack of impact the exogenously derived democracy has had on their lives or the observable politics in the country, citizens may become jaded with the system as a whole. If this is the driving mechanism that associates exogenously derived democracy and less 
attachment to democracy it is less clear what policy makers or domestic democracy advocates can do to counteract the negative effect.

\section{Unresponsive Democratization and Foreign Democracy Promotion}

The findings represented in the preceding chapters beg additional questions about the merits of foreign democracy promotion policies. The most significant and perhaps most obvious is, should the findings prompt donors to reconsider current forms of democracy promotion or democracy promotion in its entirety? On the one hand, this dissertation has illustrated that foreign promoted democratization is associated with a lack of government responsiveness, especially when it is not mirrored with a domestic democratic movement. Perhaps, quite obviously, if responsive democratization is the primary goal of donors, and in light of its likely unintended consequences, donors should re-evaluate democracy promotion efforts.

However, this conclusion is unsatisfying for several reasons. First, democracy promotion efforts obviously have many goals, and its merits should be judged against them all, not just its ability to induce responsiveness. For example, if targeted democracy promotion, like sanctioning or aid giving for the purposes of democratization can be credited for some of the real positive changes that have been made across the continent in terms of increases in political rights and civil liberties, it should not be abandoned totally. These positive changes in political rights and civil liberties enhance a different dimension of the quality of life of Africans.

However, dis-guarding democracy promotion foreign policy because of its likely impact on inducing an unresponsive democracy is, perhaps, also misguided. As, illustrated in chapters 2 and 3, direct or targeted democracy promotion efforts were not always necessary to induce a somewhat exogenously derived democracy. Put differently, not all exogenously derived democracies suffered aid sanctioning for not democratizing or received foreign aid for holding multiparty elections. 
Instead, as described in chapter 2, the post-Cold War period ushered in a new international paradigm for many African leaders. With the loss of the Soviet Union as a potential foreign patron many saw it advantageous to hold multiparty elections to attract the patronage of Western donors; the value of this particular portion of a regime's extraversion portfolio rose. In other words, a new international norm was ushered in wherein multipartyism was perceived as important and almost necessary to have credibility with donors. ${ }^{76}$ Thus, ending targeted democracy promotion will, in my opinion, likely not completely disincentivize exogenous democratization, or bring an end to multiparty elections, for example, in exogenously derived democracies. While, in this hypothetical scenario, governments would not face sanctions for democratic backsliding, many would, in my opinion, still find it in their interest to hold elections to appease what is now perceived to be the new electoral norm, or the sensibilities of the main donors.

Thus, to summarize, while this dissertation offers insights into some of the unintended consequences of democracy promotion, it probably contributes much more ambiguously towards a general policy debate about democracy promotion. Despite its impact on institutionalizing responsive democracy, to the extent that democracy promotion aids in securing higher levels of political rights and civil liberties, it should probably not be abandoned. Also, ending targeted democracy promotion policies, like sanctioning or rewarding regimes for their undemocratic or democratic behavior, will likely not change which regimes Western governments favor or the perceptions of recipient nations. As long as there is a real or perceived notion that multipartyism is favored among the main donors, regimes that are vulnerable to their relationship with donors will likely continue to have multiparty elections. Through this reasoning, exogenously induced democracies are likely to persist, with or without targeted democracy promotion policies.

\footnotetext{
${ }^{76}$ Finnemore and Sikkink (1998) discuss signaling norms as a type of international norm. The spread of multipartyism in Africa during the 1990s seems to be a signaling norm by their discussion; arguably, the spread norm of an emphasis on multiparty elections was generated by state leaders reacting to changes in the international environment, and was then widely shared and enforced by members of the international community.
} 
In terms of policy implications, then, perhaps the focal point should turn to whether an exogenous democratization can "become endogenous." The "endogenization" of a democracy would require that an exogenously derived democracy gain a deeper sense of domestic legitimacy wherein domestic civil society would have greater ownership of the political system. Like endogenous democracies, one would expect an endogenized democracy to contain that everimportant policy loop, wherein elected officials have the political incentive to act for the needs and demands of their citizenry. A focus on this brings up the following relevant policy questions: What conditions are necessary for the endogenization of an exogenously democracy? What role might donors or other actors play in endogenizing a 'surface level' democracy? I discuss these questions next, using the case of Ghana as a possible endogenized exogenously derived democracy.

\section{The Endogenization of an Exogenously Derived Democracy}

In light of Ghana's clearly exogenously influenced democratic transition, Ghana’s posttransition democratic transformations are anomalous. Unlike the vast majority of Africa's exogenously influenced democracies, there have been many signs that Ghana's democracy has obtained a significant degree of “endogeniety." In this section, I discuss what Ghana's case might offer in terms of generalizations of where an endogenization of an exogenously derived democratic experiment is likely occur and whether there are any policy implications that can be derived for the donor community in encouraging endogenization.

\section{Ghana's Exogenously Influenced Democratization}

Ghana's road to multipartyism was marred by many of the characteristics one might think are typical of an exogenously derived democracy. Like so many African countries, prior to the transition the Rawlings regime was heavily dependent upon IFI and donor support at a time when both communities were openly expressing their preferences for democratization (Sandbrook 2000: 
chapter 5; Haynes 1993). To that point, some observers interpreted the timing of Rawlings's announcement of a transition to multipartyism as a direct attempt to further attract and maintain the support of the donor community; he did so only four days before the influential donors' conference in Paris (Quaye 1995; Adejumobi 2000: 65). Additionally, while some domestic demands for democracy were present, they were heavily repressed, and as a result not well organized or particularly vocal. Ghana did not experience, for example, mass demonstrations against the government in the period leading up to the democratic transition (Sandbrook 2000: 27).

Also like many other exogenously influenced transitions, the regime's ability to suppress possible domestic opposing forces was further echoed in the nature of the transition. Once it was apparent that the regime would have to accept multipartyism to maintain support from its foreign donors, the Rawlings government institutionalized reforms swiftly (Sandbrook 2000; Adjemobi 2000: 66-67). One observer noted "the PNDC (ruling party) apparently believed that the key to 'reformwith-survival' lay in the element of surprise and in close control of the transition agenda" (ACR: 1992/1994). This close control of the transition was articulated in "every phase of the transition process, including the process of constitutional engineering, establishment and control of the electoral body, subversion of electoral rules and regulations, abuse of the electioneering process, voters' registration and the conduct of elections" (Adejumobi 2000: 67). This level of control over the transition, and possible vote-rigging, paid off for Rawlings; amid an oppositional boycott he won the first multiparty election in November of 1992 and re-secured an institutionally tilted electoral playing field as the incumbent in the subsequent election in 1996, which he also won (Adejumobi 2000: 70).

Signs of Endogenization

Although Rawlings's decision to concede multiparty elections was clearly heavily influenced by exogenous factors and the transition was heavily controlled, democracy today in Ghana shows 
several signs of a certain degree of endogenization. After its inaugural 1992 multiparty election, Ghana not only went on to observe four successive multiparty elections (1996, 2000, 2004, 2008), but the quality of each election improved over electoral cycles (Gyimah-Boadi 2009) and other democratic institutions, like the Electoral Commission, freedom in the media, and the judiciary have significantly strengthened (Gyimah-Boadi 2009).

Additionally, two of these elections resulted in party turnover and the political party dynamics have crystalized into a fairly stable two-party system (Morrison 2004). Whereas electoral quality and party turnover are important signs of a strengthening of the democratic character of a country's formal institutions, they may also give some insights into the endogenization of the democracy. Both speak to the decreasing ability with which the initial ruling party was able to distort democratic institutions and repress the opposition to maintain its incumbency. Also, in the cases of achieving party turnover and establishing a stable two party system, specifically, Ghana's democratic climate illustrates a rise of a strengthened opposition. Theoretically this gives voters a viable alternative at the poles and, in turn, politicians an electoral incentive to respond to the needs of voters.

Equally important to looking to the formal institutional setting to establish endogenization, is an examination of the political culture. Endogenous democratic transitions occur due to domestic political dynamics and are likely the articulation of a strong domestic demand for democracy and an organized civil society. This political culture is an essential signal of endogenization. Also, an endogenized democracy will sustain itself even if external pressures to be democratic subside, and thus it requires strength in a popular and domestic ownership of the regime type. Although, it is impossible to be certain that Ghana's democracy will continue to thrive in absentia of an external environment favorable to democracy, there are several signs in Ghana's current political environment that signify that its democracy has endogenized in this respect. For example, several 
observers have noted that civil society organizations in Ghana have grown in numbers and influence, and especially so in organizing interests around elections and for advocacy of various policy reforms (Gyimah-boadi 2009). Additionally, democracy in Ghana not only enjoys overwhelming public support, as data from four rounds of Afrobarometer surveys suggest, (Abdulai and Crawford 2010) but the Ghanaian public demonstrates a high degree of democratic engagement. Voter turnout since Ghana's second election has been above 70\% (Gyimah-boadi 2009; Abdulai and Crawford 2010).

Finally, this dissertation has suggested that endogenous democracies will more likely induce responsiveness in social service delivery due to a created policy-feedback loop between electorally incentivized politicians and engaged citizens. Thus a final signal of an endogenous and responsive government is that this type of policy-feedback loop be present. Giovanni Carbone's (2009) research into the evolution of healthcare policy in Ghana speaks to this point and confirms that, at least with respect to Ghanaian health policy, a policy-feedback loop has developed in Ghana's democracy:

"The overall result was a vibrant democratic life that generated strong pressures for governing parties to answer to the social concerns of the voters. A key social demand, in particular, related to the health sector and to the limited and unequal access to drugs, services and facilities under the so-called cash-and-carry system. The opposition was quick in exploiting health issues to challenge the ruling party, to articulate an electoral platform that would win it power, and, once in office, to adopt health policy changes that would help it gain a second mandate. It is difficult to overestimate the relevance of electoral competition in Ghana's recent politics of health reform" (Carbonne 2009: 14).

Ghana's case reveals that the nature of the birth of a democracy does not necessarily determine a country's democratic legacy. Its controlled and exogenously influenced transition has, by many signals, given way to a highly domestically legitimate and vibrant democracy. Comparatively, Ghana's democracy beat the odds; it is a hopeful case in light of what this dissertation has thus far documented for the vast majority of Africa's exogenously influenced democracies. Naturally, this anomaly raises the following important questions: how was this "endogenization" achieved?, can it be replicated elsewhere?, and what policy lessons can be derived from the case, particularly for the 
donor community, for the pursuit of trying to encourage endogenization elsewhere? Clearly, Ghana's case merits much more research than what this dissertation has time to explore. However, below I discuss one possible explanation for Ghana's endogenization, as well as what policy implications might be derived from the case.

\section{Ghana's Party Roots as a Source of Endogenization}

Several scholars credit Ghana’s competitive electoral environment and current democratic culture to the depth and nature of Ghana's political party roots (Sandbrook 2000: 37; Morrison 2004; Witfield 2009). Ghana's two current main parties (NDC and NPP) articulate two political traditions that emerged during decolonization (Witfield 2009; Sandbrook 2000: 117-120). "Political identity in Ghana has been formulated largely by the ideologies of the Nkrumahists and Danquah-Busiasts" (Morison 2004: 436). And although Ghana experienced a lot of regime instability post independence (four republics and three military regimes), the country also had a fairly regular showing of competitive elections; elections have been held in Ghana ever 6.2 years (Morrison 2004: 427; Sandbrook 2000: 37). This regularity in practicing competitive elections facilitated these two parties' position in becoming the default institutions with which Ghanaians would organize themselves when a competitive election arose. Put differently, due to the regular and semi-frequent opportunities for political parties to arise, the political traditions that the NDC and NPP reflect avoided fading away from Ghana’s political party imagination.

Further, the two parties have historically maintained a high two-way competitive environment; the two traditions (under various party names) have alternated in government and winners of competitive elections have usually only polled about 55 percent (Morrison 2004: 427). This competitive environment might be due to the fact that the political traditions provide an “ideological image" for Ghana’s parties, which helps to transcend ethnic, regional, urban/rural and class cleavages (Witfiedl 2009). Ghanaians can generally see either party as a viable alternative in 
power. In fact, the outcome of Ghana's elections usually relies on a large percentage of potential swing voters, which also underlines Ghana's highly politically competitive environment (Witfield 2009).

While the immergence and early sustainability of Ghana's fourth republic was clearly foreign influenced, it may have been the underlying competitive nature of democratic politics that eventually led to this case of "endogenization." As discussed above, the consolidation of a politically competitive and thriving democracy in Ghana is partially, if not mainly, attributable to its domestic history of experiencing somewhat regular multiparty elections wherein political interests articulated themselves largely within two stable political traditions/parties. Arguably, through this perspective, one might assume that Ghana had an exceptional democratic foundation underneath its bouts with authoritarianism and instability. Once the government was pressured or incentivized enough from exogenous circumstances to institutionalize the formal structures of democracy, Ghana's stable competitiveness and democratic culture awakened.

While it is clear that this case warrants more research into other possible explanations, this perspective may still offer some generalizations about the proclivity of a democracy to "endogenize." For example, perhaps Ghana's case illustrates that the endogenization of an exogenously derived democracy is likely to happen where the country has a pre-existing historical tradition of democratic competitive politics. Cases like this might only need the formal institutional structures of multiparty politics to be protected and encouraged by the outside until the competitive, domestic political atmosphere has time to further institutionalize itself. Thus, donors interested in encouraging the endogenization of democracy should focus their pressure to more fully democratize, and efforts to strengthen opposition parties on cases where an authoritarian or semi-authoritarian government faces an opposition with historic legitimacy, and where competitive politics has historically cut across social cleavages. Ghana's case also illustrates the self-reinforcing power of a democratic 
culture. Civil society activity and popular demand in Ghana is high and this is crucial for establishing a policy loop between citizens and elected officials. In this respect Ghana's case can also highlights the importance of democratic education, and democratic civil society organizations can have on endogenization. This may also be another avenue for donors to interject their influence in.

\section{Conclusion}

This dissertation has focused on the impact that the origins of democratization has on the subsequent character of a country's democracy. While this emphasis proved necessary to understanding the absence of responsive government in many of Africa's democracies, the resulting research has shed light onto important, related questions that deserves future attention. For example, much can be gained into research into establishing the other contextual environments that are most conducive for a "responsive" democracy to emerge. While the nature of a democracy's origins is clearly important to this story, Ghana's case illustrates that it is not the entire story. This focus may highlight when foreign democracy promotion for multipartyism will eventually result in an endogenized case of democracy and/or what foreign democracy promoters can do to encourage the endogenization of democracy. Additionally, the micro-processes of how policy loops form and what institutional setting they are likely to form in, seems to be particularly relevant to this project. As this dissertation illustrated, the widely assumed notion that competitive elections are sufficient to incentivize the establishment of a policy loop was a fallacy. It is important that research revolves around the contextual environment of when and how such policy loops form, and also, how such policy loops function. These micro-processes seem to strikingly under-researched. Research into these questions will not only allow us to make more sense of the unresponsive nature of African governments, but it will continue to offer more insight as to how foreign donors can assist in encouraging the a greater substance democracy. 


\section{Appendices}

Appendix I: Data Sources and Measurement for Chapter 2 Analyses

\begin{tabular}{|c|c|}
\hline Variable & Source/Measurement \\
\hline Civil Liberties & From: Freedom House \\
\hline GDP per capita & $\begin{array}{l}\text { From: IMF's World Economic Outlook Database; Measured as the log of } \\
\text { GDP per capita (PPP) }\end{array}$ \\
\hline Literacy Rate & $\begin{array}{l}\text { From: World Bank's Development Indicators; Measured as the log of }(1+ \\
\text { adult literacy rate) }\end{array}$ \\
\hline $\begin{array}{c}\text { Ethnic } \\
\text { Fractionalization }\end{array}$ & From: Alesina et al. (2003) \\
\hline Legacy & From: Bratton and van de Walle (1997:79). \\
\hline Historisis & $\begin{array}{l}\text { Measured as the number of years prior to } 1989 \text { that the country was a de } \\
\text { facto or de jure one party state. Every count starts from independence, but } \\
\text { in the cases of Liberia and Ethiopia, they start at } 1960 \text {. }\end{array}$ \\
\hline GDP Growth & $\begin{array}{l}\text { From: World Bank's Development Indicators (Sao Tome and Principe's } \\
\text { figures came from the World Economic Outlook); Measured as the GDP } \\
\text { growth annual percent. }\end{array}$ \\
\hline Oil & $\begin{array}{l}\text { From: Ross (Forthcoming); Measured as a dummy variable for whether or } \\
\text { not the country has rents from oil exports (the value per capita of their } \\
\text { export revenue over the cost per capita of their oil production) that } \\
\text { represent at least } 1 \% \text { of GDP }\end{array}$ \\
\hline Protests & $\begin{array}{l}\text { From: Bratton and van de Walle (1997). Values of } 0 \text { imputed for } \\
\text { Botswana, Gambia, Mauritius, and Senegal, after email exchange with } \\
\text { Nicolas van de Walle }(10 / 23 / 2009) \text {. }\end{array}$ \\
\hline Elections & $\begin{array}{l}\text { Self collected from multiple sources (heavily drawn from Lindberg 2003); } \\
\text { Measured as the number of elections (presidential and legislative elections) } \\
\text { that are at least } 6 \text { months apart from one another. }\end{array}$ \\
\hline Soviet & $\begin{array}{l}\text { From: Dunning (2004); Measured as a dummy variable for whether or not } \\
\text { the country was a former Soviet client. }\end{array}$ \\
\hline French & $\begin{array}{l}\text { Self coded; Measured as a dummy for whether or not the country was a } \\
\text { French colony }\end{array}$ \\
\hline $\begin{array}{l}\text { Aid as a } \% \text { of } \\
\quad \text { exports }\end{array}$ & From: World bank's World Development Indicators. \\
\hline SAL & From: www.imf.org \\
\hline Conflict & $\begin{array}{l}\text { From: PRIO; Measured as a dummy variable for if the state had internal } \\
\text { conflict (type } 2,3 \text { or } 4 \text { ) of } 1000+\text { deaths }\end{array}$ \\
\hline
\end{tabular}




\section{Appendix II: Summary Statistics of Data Used in Chapter 3}

\begin{tabular}{|l|l|l|l|l|l|}
\hline Variable & N & Mean & Std. Dev. & Min & Max. \\
\hline Life Expectancy (1990) & 48 & 52.81 & 7.79 & 32 & 70 \\
\hline$\Delta$ Life Expectancy (1990-2005) & 48 & 0.67 & 7.00 & -17 & 16 \\
\hline Infant Mortality (1990) & 48 & 96.94 & 34.38 & 17 & 169 \\
\hline$\Delta$ Infant Mortality (1990-2005) & 48 & -14.13 & 16.67 & -53 & 20 \\
\hline Undernourishment \% (1992) & 43 & 32.64 & 15.54 & 2.5 & 66 \\
\hline$\Delta$ Undernourishment \% (1992-2005) & 43 & -3.56 & 13.26 & -29 & 43 \\
\hline Primary Enrollment (1991) & 43 & 57.02 & 23.22 & 15 & 96 \\
\hline$\Delta$ Primary Enrollment (1991-2005) & 40 & 12.85 & 17.28 & -27.29 & 43.77 \\
\hline Secondary Enrollment (1990) & 45 & 21.40 & 15.24 & 4.8 & 65.98 \\
\hline$\Delta$ Secondary Enrollment (1990-2005) & 35 & 13.33 & 12.10 & -6.97 & 47.36 \\
\hline$\Delta$ Democracy Score (1990-2005) & 47 & 1.31 & 1.46 & -2.5 & 4 \\
\hline Average Population (1990-2005) & 48 & 13.20 & 20.3 & 0.08 & 117 \\
\hline Conflict & 48 & 0.58 & 0.50 & 0 & 1 \\
\hline Average Urbanization (1990-2005) & 48 & 34.94 & 15.91 & 7.81 & 81.28 \\
\hline Age of Democracy & 48 & 9.88 & 8.69 & 0 & 40 \\
\hline Ethnic Fractionalization & 47 & 0.66 & 0.23 & 0 & 0.93 \\
\hline Authoritarian & 48 & 0.08 & 0.28 & 0 & 1 \\
\hline Exogeneity & 47 & 1.40 & 0.77 & 0 & 2 \\
\hline GDP per capita, (PPP), ln & 47 & 6.21 & 1.01 & 4.85 & 9.04 \\
\hline Control of Corruption (1996-2005) & 48 & -0.62 & 0.59 & -1.71 & 0.82 \\
\hline
\end{tabular}


Appendix III: The Exogeneity of Transitions by Afrobarometer Sample, Chapter 5

\begin{tabular}{|l|l|l|}
\hline 0 on the Exogenous Scale & 1 on the Exogenous Scale & 2 on the Exogenous Scale \\
\hline Botswana & Benin & Burkina Faso \\
\hline Senegal & Cape Verde & Ghana \\
\hline & Madagascar & Kenya \\
\hline & Malawi & Lesotho \\
\hline & Mali & Liberia \\
\hline & Nigeria & Mozambique \\
\hline & South Africa & Namibia \\
\hline & Zambia & Tanzania \\
\hline & & Uganda \\
\hline & & Zimbabwe \\
\hline
\end{tabular}




\section{Appendix IV: Details on the Question Wording and Construction of Control Variables Used, Chapter $5^{7}$}

\begin{tabular}{|c|c|c|}
\hline 苞 & $\begin{array}{c}\text { Passive } \\
\text { Citizenship }\end{array}$ & $\begin{array}{l}\text { Factor Variable created based on the responses to two questions, which both ask the } \\
\text { respondent to what degree they agree with two statements. The first set of statements } \\
\text { are: } \\
\text { 1) Statement 1: Citizens should be more active in questioning the actions of leaders. } \\
\text { Statement 2: In our country, citizens should show more respect for authority" } \\
\text { The second set are: } \\
\text { 2) Statement 1: Government is like an employee; the people should be the bosses } \\
\text { who control the government } \\
\text { Statement 2: People are like children; the government should take care of them } \\
\text { like a parent. } \\
\text { Possible responses to both are: } \\
\text { 1) Agree very strongly with Statement } 1 \text {, } \\
\text { 2) Agree with Statement 1, } \\
\text { 3) Agree with Statement 2, } \\
\text { 4) Agree very strongly with Statement } 2 \\
\text { Principle components factor analysis extracted a single factor (eigenvalue = 1.02), which } \\
\text { explains } 51.06 \% \text { of the common variance. }\end{array}$ \\
\hline U & $\begin{array}{c}\text { National } \\
\text { Identification }\end{array}$ & $\begin{array}{l}\text { Let us suppose that you had to choose between being a [Ghanaian] and being a } \\
\text { [Respondent's Ethnic group]. Which of the following best expresses your feelings? } \\
\text { 1) I feel only (respondent's ethnic group) } \\
\text { 2) I feel more (respondent's ethnic group) than [Ghanaian] } \\
\text { 3) I feel equally [Ghanaian] and (respondent's ethnic group) } \\
\text { 4) I feel more [Ghanaian] than (respondent's ethnic group) } \\
\text { 5) I feel only [Ghanaian] }\end{array}$ \\
\hline U & $\begin{array}{l}\text { Trust in } \\
\text { Co-nationals }\end{array}$ & $\begin{array}{l}\text { How much do you trust each of the following types of people: Other [Ghanaians]? } \\
\text { 0) Not at all } \\
\text { 1) Just a little } \\
\text { 2) I trust them somewhat } \\
\text { 3) I trust them a lot }\end{array}$ \\
\hline
\end{tabular}

\footnotetext{
${ }^{77}$ All question wording and responses reflect how the variable was recoded for analyses, and may not be consistent with the original version of the Afrobarometer survey.
} 


\begin{tabular}{|c|c|c|}
\hline 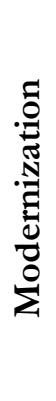 & $\begin{array}{c}\text { Living } \\
\text { Conditions }\end{array}$ & $\begin{array}{l}\text { In general, how would you describe: Your own present living conditions? } \\
\text { 1) Very Bad } \\
\text { 2) Fairly Bad } \\
\text { 3) Neither good nor bad } \\
\text { 4) Fairly good } \\
\text { 5) Very good } \\
\text { *This was the closest question the Afrobarometer had to "income" }\end{array}$ \\
\hline 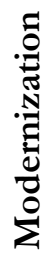 & Gender & $\begin{array}{l}\text { 0) Female } \\
\text { 1) Male }\end{array}$ \\
\hline 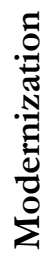 & Urban & $\begin{array}{ll}\text { 0) } & \text { Rural } \\
\text { 1) } & \text { Urban }\end{array}$ \\
\hline 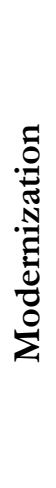 & Education & $\begin{array}{l}\text { What is the highest level of education you have completed? } \\
\text { 0) No formal Schooling } \\
\text { 1) Informal schooling only (including Koranic schooling) } \\
\text { 2) Some primary schooling } \\
\text { 3) Primary school complete } \\
\text { 4) Some secondary/high school } \\
\text { 5) Secondary school completed/high school completed } \\
\text { 6) Post-secondary qualifications, other than University } \\
\text { 7) Some University } \\
\text { 8) University Completed }\end{array}$ \\
\hline 番 & $\begin{array}{l}\text { Years in } \\
\text { Democracy }\end{array}$ & $\begin{array}{l}\text { The number of years since the age of } 18 \text { that the respondent has lived under a } \\
\text { democratic system. }\end{array}$ \\
\hline
\end{tabular}




\begin{tabular}{|c|c|c|}
\hline & News & $\begin{array}{l}\text { Factor Variable created based on the responses to three questions, all of which ask } \\
\text { respondents how often the respondent gets the news from specific sources: } \\
\text { 1) Radio } \\
\text { 2) TV } \\
\text { 3) Paper } \\
\text { Possible responses to all three are: } \\
\text { 0) Never } \\
\text { 1) Less than once a month } \\
\text { 2) A few times a month } \\
\text { 3) A Few times a week } \\
\text { 4) Every day } \\
\text { Principle components factor analysis extracted a single factor (eigenvalue = 1.79), which } \\
\text { explains } 59.86 \% \text { of the common variance. }\end{array}$ \\
\hline م્ل & Political Interest & $\begin{array}{l}\text { When you get together with your friends or family, would you say you discuss political } \\
\text { matters: } \\
\text { 0) Never } \\
\text { 1) Occasionally } \\
\text { 2) Frequently }\end{array}$ \\
\hline & $\begin{array}{l}\text { Political } \\
\text { Knowledge }\end{array}$ & $\begin{array}{l}\text { Factor Variable created based on the responses to two questions, both of which ask } \\
\text { respondents to correctly identify the name of various politicians: } \\
\text { 1) Respondent's Member of Parliament } \\
\text { 2) Finance Minister } \\
\text { Responses were coded as: } \\
\text { 0) Incorrect or guess } \\
\text { 1) Correctly Identified } \\
\text { Principle components factor analysis extracted a single factor (eigenvalue }=1.09 \text { ), which } \\
\text { explains } 54.54 \% \text { of the common variance. }\end{array}$ \\
\hline
\end{tabular}




\begin{tabular}{|c|c|c|}
\hline 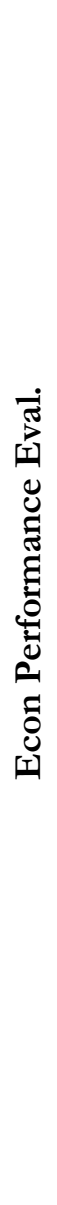 & $\begin{array}{l}\text { Evaluations of } \\
\text { the Economy }\end{array}$ & $\begin{array}{l}\text { Two Factor Variables were created based on the responses to four questions: } \\
\text { Retrospective Macro Evaluation: } \\
\text { 2) Looking back, how do you rate the following compared to twelve months ago: } \\
\text { Economic Conditions in this country? } \\
\text { Prospective Macro Evaluation: } \\
\text { 3) Looking ahead, how do you rate the following compared to twelve months ago: } \\
\text { Economic Conditions in this country? } \\
\text { Retrospective Micro Evaluation: } \\
\text { 4) Looking back, how do you rate the following compared to twelve months ago: } \\
\text { Your living conditions? } \\
\text { Prospective Micro Evaluation: } \\
\text { 5) Looking ahead, how do you rate the following compared to twelve months ago: } \\
\text { Your living conditions? } \\
\text { 1) Much worse } \\
\text { 2) Worse } \\
\text { 3) Same } \\
\text { 4) Better } \\
\text { 5) Much Better } \\
\text { Principle components factor analysis extracted two factors, with eigenvalues of } 2.39 \text { and } \\
\text { 1.09 respectively; Collectively they explain which explains } 87.10 \% \text { of the variance. } \\
\text { Prospective economic evaluations loaded highly and similarly on the first factor, and } \\
\text { retrospective economic evaluations loaded highly on the second. }\end{array}$ \\
\hline 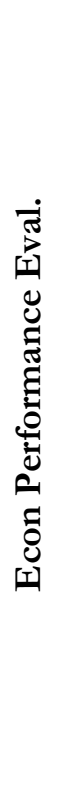 & $\begin{array}{l}\text { Economic Policy } \\
\text { Performance }\end{array}$ & $\begin{array}{l}\text { Factor Variable created based on the responses to five questions, all of which ask how } \\
\text { well or badly the current government is handling the specific economic policies: } \\
\text { 1) Managing the economy } \\
\text { 2) Improving the living standards of the poor } \\
\text { 3) Creating jobs } \\
\text { 4) Keeping prices down } \\
\text { 5) Narrowing gaps between rich and poor } \\
\text { The following possible responses apply to all five questions: } \\
\text { 1) Very badly } \\
\text { 2) Fairly badly } \\
\text { 3) Fairly well } \\
\text { 4) Very well } \\
\text { Principle components factor analysis extracted a single factor (eigenvalue = 3.18), which } \\
\text { explains } 63.63 \% \text { of the common variance. }\end{array}$ \\
\hline
\end{tabular}




\begin{tabular}{|c|c|c|}
\hline 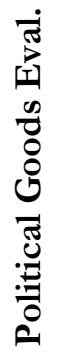 & Free Speech & $\begin{array}{l}\text { In this country, how free are you: To say what you think? } \\
\text { 1) Not at all free } \\
\text { 2) Not very free } \\
\text { 3) Somewhat free } \\
\text { 4) Completely Free }\end{array}$ \\
\hline 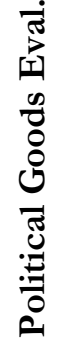 & Free Elections & $\begin{array}{l}\text { On the whole, how would you rate the freeness and fairness of the last national election, } \\
\text { held in [year]. Was it: } \\
\text { 1) Not free and fair } \\
\text { 2) Free and fair, with major problems } \\
\text { 3) Free and fair, but with minor problems } \\
\text { 4) Completely free and fair }\end{array}$ \\
\hline 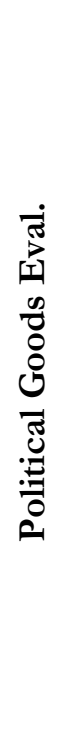 & Trust Leadership & $\begin{array}{l}\text { Factor variable created based on the responses to four questions, all of which ask how } \\
\text { much the respondent trusts each of the specific people/institutions in power: } \\
\text { 1) The President } \\
\text { 2) Parliament } \\
\text { 3) National Election Commissioner } \\
\text { 4) Local Government Councilor } \\
\text { The following possible responses apply to all four questions: } \\
\text { 0) Not at all } \\
\text { 1) Just a little } \\
\text { 2) Somewhat } \\
\text { 3) A lot } \\
\text { Principle components factor analysis extracted a single factor (eigenvalue = 2.68), which } \\
\text { explains } 66.93 \% \text { of the common variance. }\end{array}$ \\
\hline
\end{tabular}




\begin{tabular}{|c|c|c|}
\hline 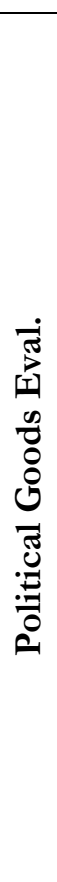 & $\begin{array}{l}\text { Perceived } \\
\text { Government } \\
\text { Corruption }\end{array}$ & $\begin{array}{l}\text { Factor variable created based on the responses to six questions, all of which ask how } \\
\text { many of the following people do the respondents think are involved in corruption of the } \\
\text { following groups: } \\
\text { 1) The President and Officials in his/her Office } \\
\text { 2) Members of Parliament } \\
\text { 3) Assembly Men/women } \\
\text { 4) Government Officials } \\
\text { 5) Tax officials } \\
\text { 6) Judges } \\
\text { The following possible responses apply to all six questions: } \\
\text { 0) None } \\
\text { 1) Some of them } \\
\text { 2) Most of them } \\
\text { 3) All of them } \\
\text { Principle components factor analysis extracted a single factor (eigenvalue = 3.90), which } \\
\text { explains } 65.0 \% \% \text { of the common variance. }\end{array}$ \\
\hline 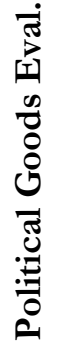 & $\begin{array}{c}\text { Fair Treatment } \\
\text { of Ethnicity }\end{array}$ & $\begin{array}{l}\text { How often are [respondent's ethnic group] treated unfairly by the government? } \\
\text { 0) Never } \\
\text { 1) Sometimes } \\
\text { 2) Often } \\
\text { 3) Always }\end{array}$ \\
\hline
\end{tabular}




\begin{tabular}{|c|c|c|}
\hline 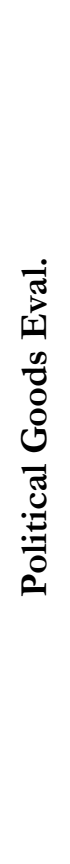 & $\begin{array}{c}\text { Perceived } \\
\text { Government } \\
\text { Responsiveness }\end{array}$ & $\begin{array}{l}\text { Factor variable created based on the responses to seven questions, all of which ask how } \\
\text { well the current government is following the specific policies/problems: } \\
\text { 1) Reducing crime } \\
\text { 2) Improving basic health services } \\
\text { 3) Addressing educational needs } \\
\text { 4) Providing water and sanitation services } \\
\text { 5) Ensuring everyone has enough to eat } \\
\text { 6) Maintaining Roads and Bridges } \\
\text { 7) Providing a reliable supply of electricity } \\
\text { The following possible responses apply to all six questions: } \\
\text { 1) Very badly } \\
\text { 2) Fairly badly } \\
\text { 3) Fairly well } \\
\text { 4) Very well } \\
\text { Principle components factor analysis extracted a single factor (eigenvalue = 3.40), which } \\
\text { explains 48.51\% of the common variance. }\end{array}$ \\
\hline 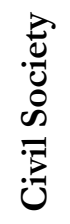 & Partisanship & $\begin{array}{l}\text { Do you feel close to any particular political party? } \\
\text { 0) No } \\
\text { 1) Yes }\end{array}$ \\
\hline $\begin{array}{l}\stackrel{2}{0} \\
\cdot \frac{0}{0} \\
0 \\
0 \\
0 \\
0 \\
0\end{array}$ & $\begin{array}{l}\text { Civil Society } \\
\text { Member }\end{array}$ & $\begin{array}{l}\text { Let's turn to your role in the community. Now I am going to read out a list of groups } \\
\text { that people join or attend. For each one, could you tell me whether you are an official } \\
\text { leader, an active member, an inactive member or not a member: Some other voluntary } \\
\text { association or community group? } \\
\text { 0) Not a member } \\
\text { 1) Inactive member } \\
\text { 2) Active member } \\
\text { 3) Official leader }\end{array}$ \\
\hline
\end{tabular}




\begin{tabular}{|c|c|c|}
\hline 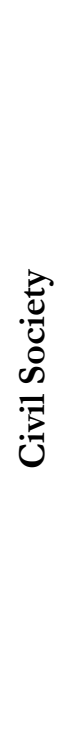 & $\begin{array}{c}\text { Active in Civil } \\
\text { Society }\end{array}$ & $\begin{array}{l}\text { Factor variable created based on the responses to three questions, all of which ask } \\
\text { whether a person would engage in the following activities if they had the chance: } \\
\text { 1) Attend a community meeting } \\
\text { 2) Get together with others to raise an issue } \\
\text { 3) Attend a demonstration or protest march } \\
\text { The following possible responses apply to all three questions: } \\
\text { 0) No, would never do this } \\
\text { 1) No, but would do if had the chance } \\
\text { 2) Yes, one or twice } \\
\text { 3) Yes, several times } \\
\text { 4) Yes, Often } \\
\text { Principle components factor analysis extracted a single factor (eigenvalue = 1.82), which } \\
\text { explains } 60.63 \% \text { of the common variance. }\end{array}$ \\
\hline 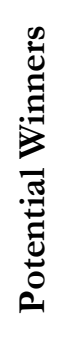 & $\begin{array}{c}\text { Member of } \\
\text { Majority Ethnic } \\
\text { Group }\end{array}$ & $\begin{array}{l}\text { Coded as a } 1 \text { or } 0 \text { if the respondent identified him/herself has a member of the } \\
\text { numerical majority ethnic group. } \\
\text { For Botswana, all Tswana tribes are coded as the majority. For Lesotho, anyone not } \\
\text { identifying as European, was coded as part of the majority. All Cape Verdeans were } \\
\text { coded as part of the majority. Both Hausa and Foulani in Nigeria were coded as the } \\
\text { majority. Most information regarding which ethnic group was the numerical majority was } \\
\text { taken from the database on "www.joshuaproject.net" }\end{array}$ \\
\hline 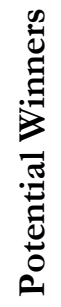 & $\begin{array}{l}\text { Ruling Party } \\
\text { Supporter }\end{array}$ & $\begin{array}{l}\text { If a presidential election were held tomorrow, which party's candidate would you vote } \\
\text { for? } \\
\text { Coded as a } 0 \text { or a } 1 \text { for whether the respondent stated that they supported the ruling } \\
\text { party at the time of } 2008 \text { (when the survey was distributed). }\end{array}$ \\
\hline
\end{tabular}




\section{Works Cited}

(ACR). ((Multiple Years)). African Contemporary Record. London: Holmes and Meier Publishers.

(ACR). (Multiple Years). African Contemporary Record. London: Holmes and Meier Publishers.

(ARB). (1989-1995). Africa Research Bulletin: Political Series. Oxford: Blackwell Publishers.

(CRS). (2007). Zambia: Livelihoods Assessment. Catholic Relief Services (internal document), with funding from USAID.

Abdulai, A.-G., \& Crawford, G. (2010). Consolidating Democracy in Ghana: Progress and Prospects? Democratization, 17 (1), 26-67.

Acemoglu, D., \& Robinson, J. (2005). Economic Origins of Dictatorship and Democracy. Cambridge: Cambridge University Press.

Achen, C. (1992). Social Psychology, Demographic Variables and the Linear Regression: Breaking the Iron Triange in Voter Research. Political Behavior, 14 (3), 195-211.

Adejumobi, S. (2000). Elections in Africa: A Fading Shadow of Democracy? International Political Science Review , 21 (1), 59-73.

(1989-1995). Africa Research Bulletin (ARB): Political Series. Oxford: Blackwell Publishers.

Africa South of the Sahara (ASS). (1989-1995). London: Taylor and Francis Group.

Alesina, A., Devleeschauwer, A., Easterly, W., Kurlat, S., \& Wacziarg, R. (2003). Fractionalization. Journal of Economic Growth, 8 (2), 155-194.

Almond, G., \& Verba, S. (1963). The Civic Culture: Political Attitudes and Democracy in Five Nations. Princeton: Princeton University Press.

Arifari, N. B. (2006). We Don't Eat the Papers: Corruption in Transport, Customs and the Civil Forces. In G. Blundo, \& J.-P. Olivier de Sardan, Everyday Corruption and the State: Citizens and Public Officials in Africa (pp. 69-109). London: Zed Books. 
Avelino, G., Brown, D., \& Hunter, W. (2001). Globalization, Democracy and Social Spending in Latin America, 1980-1997. Boulder: University of Colorado.

Baker, B. (1998). The class of 1990: How have the autocratic leaders of sub-Saharan Africa fared under democratization? Third World Quarterly, 19 (1), 115-127.

Bardhan, P., \& Mookherjee, D. (2000). Capture and Governance at Local and National Levels. The American Economic Review, 90 (2), 135-139.

Bardhan, P., \& Mookherjee, D. (2005). Decentralizing Antipoverty Program Delivery in Developing Countries. Journal of Public Economics, 89 (4), 675-704.

Barkan, J., Ademolekun, L., Zhou, Y., Laleye, M., \& Ng'ethe, N. (2004). Emerging Legislatures: Institutions of Horizontal Accountability. In B. Levy, \& S. Kpundeh, Building State Capacity in Africa: New Approaches, Emerging Lessons (pp. 211-255). Washington D.C.: The World Bank.

Barro, R. (1973). The Control of Politicians: An Economic Model. Public Choice , 14 (1), 19-42.

Bates, R. (1983). Modernization, Ethnic Competition, and the Rationality of Politics in Contemporary Africa. In D. Rothchild, \& V. Olorunsola, State versus Ethnic Claims: African Policy Dilemmas (pp. 152-171). Boulder: Westview.

Bates, R. (2008). When Things Fell Apart: State Failure in Late-Century Africa. Cambridge: Cambridge University Press.

Baum, M., \& Lake, D. (2003). The Political Economy of Growth: Democracy and Human Capital. American Journal of Political Science , 47 (2), 333-347.

Bayart, J.-F. (2000). Africa in the World: A History of extraversion. African Affairs, 99, 217-267.

Bayart, J.-F. (1993). The State in Africa: The Politics of the Belly. London: Longman.

Baylies, C., \& Szeftel, M. (1997). The 1996 Zambian Elections: Still Awaiting Democratic Consolidation. Review of African Political Economy, 71, 113-128. 
Besley, T., \& Coate, S. (2003). Centralized versus Decentralized Provision of Local Goods: A Political Economy Approach. Journal of Public Economics , 87 (12), 2611-2637.

Bienen, H., \& Herbst, J. (1996). The Relationship between Political and Economic Reform in Africa. Comparative Politics, 29 (1), 23-42.

Bjornlund, E., Bratton, M., \& Gibson, C. (1992). Observing Multiparty Elections in Africa: Lessons From Zambia. African Affairs, 91, 405-431.

Boix, C. (2001). Democracy, Development, and the Public Sector. American Journal of Political Science, $45(1), 1-17$.

Boulding, C., \& Hyde, S. (2008). Political Terror, Election Fraud, and Foreign Aid: When do donors withdraw aid to promote democracy? Presented at the Midwest Political Science Association , 1-20.

Bratton, M. (1994). Civil Society and Political Transition in Africa. IDR Reports.

Bratton, M. (1992). Zambia Starts Over. Journal of Democracy , 3 (2), 81-94.

Bratton, M., \& Mattes, R. (2001a). Support for Democracy in Africa: Intrinsic or Instrumental? British Journal of Political Science, 31, 447-474.

Bratton, M., \& Mattes, R. (2001b). Africans' Surprising Universalism. Journal of Democracy, 12 (1), 107-121.

Bratton, M., \& van de Walle, N. (1997). Democratic Experiments in Africa. Cambridge: Cambridge University Press.

Bratton, M., \& van de Walle, N. (1994). Neopatrimonial Regimes and Political Transitions in Africa. World Politics , 46 (4), 453-489.

Bratton, M., \& van de Walle, N. (1992). Popular Protest and Political Reform in Africa. Comparative Politics , 24 (4), 419-442.

Bratton, M., Mattes, R., \& Gyimah-Boadi, E. (2004). Public Opinion, Democracy, and Market Reform in Africa. New York: Cambridge University Press. 
Brautigam, D. (2009). The Dragon's Gift. New York: Oxford University Press.

Brown, D. (1999). Reading, Writing, and Regime Type: Democracy's Impact on Primary School Enrollment. Political Research Quarterly, 52 (4), 681-707.

Brown, D., \& Hunter, W. (1999). Democracy and Social Spending in Latin America, 1980-92. The American Political Science Review, 93 (4), 779-790.

Brown, S. (2004). Born-Again Politicians Hijacked our Revolution: Reassessing Malawi's Transition to Democracy. Canadian Journal of African Studies, 38 (3), 705-722.

Brown, S. (2005). Foreign Aid and Democracy Promotion: Lessons from Africa. The Journal of Development Research , 17 (2), 179-198.

Bueno de Mesquita, B., Smith, A., Siverson, R., \& Morrow, J. (2003). The Logic of Political Survival. Cambridge: MIT Press.

Cahen, M. (2005). Success in Mozambique? In S. Chesterman, M. Ignatieff, \& R. Thakur, Making States Work: State Failure and the Crisis of Governance (pp. 213-233). New York: United Nations University Press.

Callagy, T. (1990). Lost Between State and Market: The Politics of Economic Adjustment in Ghana, Zambia and Nigeria. In J. M. Nelson, Economic Crisis and Police Choice. The Politics of Adjustment in the Third World (pp. 257-320). Princeton: Princeton University Press.

Canache, D., Mondak, J., \& Seligson, M. (2001). Meaning and Measurement in Cross-National Research on Satisfaction with Democracy. Public Opinion Quarterly, 65 (4), 506-528.

Carbonne, G. (2009). Do New Democracies Deliver Social Welfare? Political Regimes and Health Policy in Ghana and Cameroon. Presented at the 52nd Annual Meeting of the African Studies Association.

Carothers, T. (1999). Aiding Democracy Abroad: The Learning Curve. Washington D.C.: Carnegie Endowment for International Peace. 
Carothers, T. (2006). The Backlash Against Democracy Promotion. Foreign Affairs, 85 (2), 55-68.

Carothers, T. (2002). The End of the Transition Paradigm. Journal of Democracy, 13 (1), 5.

Cartothers, T. (2002). The End of the Transition Paradigm. Journal of Democracy, 13 (1), 5-21.

Chabal, P., \& Daloz, J.-P. (1999). Africa Works: the Political Instrumentalization of Disorder. Bloomington, IN: International African Institute in association with James Currey and Indiana University Press.

Chikulo, B. (2009). Local Governance Reforms in Zambia: A Review. Commonwealth Journal of Local Governance (2), 98-106.

Chu, Y.-h., Bratton, M., Lagos, M., Shastri, S., \& Tessler, M. (2008). Public Opnion and Democratic Legitimacy. Journal of Democracy, 19 (2), 75-87.

Clapham, C. (1996). Africa and the International System: The Politics of State Survival. Cambridge: Cambridge University Press.

Clark, J. (1994). Elections, Leadership and Democracy. Africa Today , 41 (3), 41-60.

Cooper, F. (2002). Africa since 1940: The Past of the Present. Cambridge: Cambridge University Press.

Crawford, G. (1997). Foreign aid and political conditionality: Issues of effectiveness and consistency. Democratization , 4 (3), 69-108.

Crawford, G. (2001). Foreign Aid and Political Reform. New York: Palgrave.

Crawford, G. (2001). Foreign Aid and Political Reform: A Comparative Analysis of Democracy Assistance and Political Conditionality. New York: Palgrave.

Dahl, R. (1971). Polyarchy: Participation and Opposition. New Haven: Yale University Press.

Deacon, R. (2003). Dictatorship, Democracy, and the Provision of Public Goods. http:/ / econ.ucsb.edu/papers/wp20-30.pdf.

Deacon, R. (2009). Public Good Provision Under Dictatorship and Democracy. Public Choice, 139 (1-2), 241-262. 
Diamond, L. (1999). Developing Democracy: Toward Consolidation. Baltimore: The Johns Hopkins University Press.

Diamond, L. (1997). Prospects for Democratic Development in Africa. Standford: The Hoover Institute.

Diamond, L. (2002). Thinking about Hybrid Regimes. Journal of Democracy, 13 (2), 21-35.

Dowd, R., \& Driessen, M. (2008). Ethnic Voting and the Quality of Democracy in sub-Saharan Africa. Afrobarometer Working Paper.

Downs, A. (1957). An Economic Theory of Democracy. Boston: Addison Wesley.

Dunning, T. (2004). Conditioning the Effects of Aid: Cold War Politics, Donor Credibility, and Democracy in Africa. International Organization, 58 (Spring), 409-423.

Easterly, W. (2002). The Elusive Quest for Growth: An Economist's Adventures and Misadventures in the Tropics. London: Cambridge.

Easterly, W., \& Levine, R. (1997). Africa's Growth Tragedy: Policies and Ethnic Divisions. The Quarterly Journal of Economics, 112 (4), 1203-1250.

Edwards, M. (1994). International NGOs and Southern Governments in the New World Order. In A. Clayton, Governance, Democracy and Conditionality: What Role for NGOS? (pp. 65-84). Oxford: Intrac.

Eifert, B., Miguel, E., \& Posner, D. (2010). Political Competition and Ethnic Identification in Africa. American Journal of Political Science , 54 (2), 494-510.

Engedayehu, W. (1993). Ethiopia: Democracy and the Politics of Ethnicity. Africa Today , 40 (2), 2952.

Englebert, P., \& Tull, D. (2008). Postconflict Reconstruction in Africa: Flawed Ideas about Failed States. International Security, 32 (4), 106-139.

Enikolopov, R., \& Zhuravskaya. (2007). Decentralization and Political Institutions. Journal of Public Economics, 91 (11-12), 2261-2290. 
Evans, G., \& Rose, P. (2007). Support for Democracy in Malawi: Does Schooling Matter? World Development , 35 (5), 904-919.

Faguet, J.-P. (2004). Does Decentralization Increase Government Responsiveness to Local Needs?: Evidence from Bolivia. Journal of Public Economics, 88 (3-4), 867-893.

Fails, M. (2009). Does Substantive Democratization Create More Committed Democrats? Surprising Evidence in Africa. Democratization, 16 (5), 841-866.

Fatton, R. (1986). Clientelism and Patronage in Senegal. African Studies Review, 29 (4), 61-78.

Fearon, J. (1999). Electoral Accountability and the Control of Politicians: Selecting Good Types versus Sanctioning Poor Performance. In A. Przeworski, S. Stokes, \& B. Manin, Democracy, Accountability and Representation (pp. 55-98). Cambridge: Cambridge University Press.

Ferreira, P. M. (2004). Guinea-Bissau. African Security Review, 13 (4).

Finkel, S., Sabatini, C., \& Bevis, G. (2000). Civic Education, Civil Society, and Political Mistrust in a Developing Democracy: The Case of the Dominican Republic. World Development, 28 (11), 1851-1874.

Finnemore, M., \& Sikking, K. (1998). International Norm Dynamics and Political Change. International Organization, 52, 887-917.

Freedom House. (2010). Country Report: Zambia (2010). Freedom House.

Freedom House. (2010). Zambia Country Report for 2010. http: / freedomhouse.org/template.cfm?page $=22 \&$ country $=7951 \& y e a r=2010$.

Frey, S., \& Al-Roumi, A. (1999). Political Democracy and the Physical Quality of Life: The CrossNational Evidence. Social Indicators Research , 47, 73-97.

Frynas, J., Wood, G., \& Soares de Oliveira, R. (2003). Business and Politics in Sao Tome e Principe: from cocoa monoculture to petro-state. African Affairs, 102, 51-80. 
Gazibo, M. (2005). Foreign Aid and Democratization: Benin and Niger Compared. African Studies Review , 48 (3), 67-87.

Ghobarah, H., Huth, P., \& Russett, B. (2004). Comparative Public Health: The Political Economy of Human Misery and Well Being. International Studies Quarterly, 48 (1), 73-94.

Graham, C. (1994). Safety nets, politics, and the poor: transitions to market economies. Washington D.C.: The Brooking Institution.

Gregory, M. (1980). Rhodesia: From Lusaka to Lancaster House. The World Today, 36 (1), 11-18.

Gros, J.-G. (1995). The Hard Lessons of Cameroon. Journal of Democracy , 6 (3), 112-127.

Gyimah-Boadi, E. (2009). Another Step for Ghana. Journal of Democracy , 20 (2), 138.

Gyimah-Boadi, E. (1996). Civil Society in Africa. Journal of Democracy, 7 (2), 118-132.

Habyarimana, J., Humphreys, M., Posner, D., \& Weinstein, J. (2009). Coethnicity: Diversity and the Dilemmas of Collective Action. New York: Russell Sage Foundation.

Habyarimana, J., Humphreys, M., Posner, D., \& Weinstein, J. (2007). Why Does Ethnic Diversity Undermine Public Goods Provision? American Political Science Review , 101 (4), 709-725.

Hawkins, J. (1991). Understanding the Failure of IMF Reform: The Zambian Case. World Development , $19(7), 839-849$.

Haynes, J. (1993). Sustainable Democracy in Ghana: Problems and Prospects. Third World Quarterly, 14 (3), 451-467.

Herbst, J. (2000). States and Power in Africa: Comparative Lessons in Authority and Control. Princeton: Princeton University Press.

Hook, S. (1998). 'Building democracy' through foreign aid: The limitations of United States political conditionalities, 1992-96. Democratization , 5 (3), 156-180.

Horowitz, D. (1985). Ethnic Groups in Conflict. Berkeley and Los Angeles: University of California Press. 
Huber, E., Mustillo, T., \& Stephens, J. (2004). Determinants of Social Spending in Latin America. Las Vegas: Paper prepared for the Congress of the Latin American Studies Association. Hughes, N. (1996). Democracy and Imperial Rivalry in Equatorial Guinea. Review of African Political Economy, 23 (69), 442-445.

Huntington, S. P. (1968). Political Order in Changing Societies . New Haven, CT: Yale University Press. Inglehart, R. (1997). Modernization and Postmodernization: Cultural, Economic and Political Change in 43 Societies. Princeton: Princeton University Press.

Inglehart, R. (1997). The Trend Toward Postmaterialist Values Continues. In T. N. Clark, \& M. Rempel (Eds.), Citizen politics in post-industrial societies (pp. 57-66). Boulder, CO: Westview.

Inglehart, R., \& Baker, W. (2000). Modernization, Cultural Change, and the Persistence of Traditional Values. American Sociological Review , 65 (1), 19-51.

Inglehart, R., \& Weizel, C. (2005). Modernization, Cultural Change, and Democracy: The Human Development Sequence. Cambridge: Cambridge University Press.

Inglehart, R., \& Welzel, C. (2009). How Development Leads to Democracy: What We Know about Modernization. Foreign Affairs , 88 (2), 33-48.

Inglehart, R., \& Welzel, C. (2005). Modernization, Cultural Change, and Democracy. Cambridge: Cambridge University Press.

Inkeles, A., \& Smith, D. (1974). Becoming Modern. Cambridge: Harvard University Press. Jackson, R. (1990). Quasi-States: Sovereignty, International Relations, and the Third World. Cambridge: Cambridge University Press.

Jackson, R., \& Rosberg, C. (1984). Personal Rule: Theory and Practice in Africa. Comparative Politics, $16(4), 421-442$.

James, L., \& Brett, J. (1984). Mediators, Moderators, and Tests for Mediation. Journal of Applied Psychology , 69 (2), 307-321. 
Jeffries, R., \& Thomas, C. (1993). The Ghanian Election of 1992. African Affairs, 92 (368), 331-336.

Jensen, N., \& Wantchekon, L. (2004). Resource Wealth and Political Regimes in Africa. Comparative Political Studies, 37 (7), 816-841.

Joireman, S. (2004). Colonization and the Rule of Law: Comparing the Effectiveness of Common Law and Civil Law Countries. Constitutional Political Economy, 15 (4), 315-338.

Joseph, R. (1998). Africa, 1990-1997: From Abertura to Closure. Journal of Democracy , 9 (2), 3-37.

Joseph, R. (1997). Democratization in Africa after 1989: Comparative and Theoretical Perspectives. Comparative Politics, 29 (3), 363-382.

Jourde, C. (2007). The International Relations of Small Neoauthoritarian States: Islamism, Warlordism, and the Framing of Stability. International Studies Quarterly, 51 (2), 481-503.

Kaiser, P. (1999). Power, Sovereignty, and International Election Observers: The case of Zanzibar. Africa Today , 46 (1), 29-46.

Kaiser, P. (1999). Power, Sovereignty, and International Election Observers: The case of Zanzibar. Africa Today , 46 (1), 29-46.

Kaufman, R., \& Segura-Ubiergo, A. (2001). Globalization, Domestic Politics, and Social Spending in Latin America: A Time-Series Cross-Section Analysis, 1973-97. World Development, 53 (4), 553-587.

Keefer, P. (2007). Clientelism, Credibility, and the Policy Choices of Young Democracies. American Journal of Political Science, 51 (4), 804-821.

Keefer, P., \& Khemani, S. (2005). Democracy, Public Expenditures, and the Poor: Understanding Political Incentives for Providing Public Services. The World Bank Research Observer, 20 (1), 1 27.

Kees van Donge, J. (1998). Reflections on donors, opposition and popular will in the 1996 Zambian General Elections. The Journal of Modern African Studies , 36 (1), 71-99. 
Kees van Donge, J. (2009). The plundering of Zambian resources by Frederick Chiluba and his friends: A case study of the interaction between national politics and the international drive towards good governance. African Affairs, 108 (430), 69-90.

Khaleghian, P. (2004). Decentralization and Public Services: the Case of Immunization. Social Science and Medicine, 59 (1), 163-183.

Kramon, E., \& Posner, D. (2010). Who is Favored? How the Outcomes One Studies Affects the Answer One Gets? WGAPE Working Paper.

Lake, D. A., \& Baum, M. (2001). The Invisible Hand of Democracy: Political Control and the Provision of Public Services. Comparative Political Studies, 34 (6), 587-621.

Larmer, M. (2006). A Little Bit Like a Volcano-The United Progressive Party and Resistance to One Party Rule in Zambia 1964-1980. The International Journal of African Historical Studies , 39 (1), 49-83.

Larmer, M. (2009). Zambia since 1990: Paradoxes of Democratic Transition. In A. Mustapha, \& L. Witfield, Turning Points in African Democracy. Rochester, NY: Boydell and Brewer Ltd. .

Lerner, D. (1958). The Passing of traditional Society: Modernizing the Middle East. New York: Free Press. Levitsky, S., \& Way, L. (2002). Elections Without Democracy: The Rise of Competitive Authoritarianism. Journal of Democracy , 13 (2), 51-65.

Levitsky, S., \& Way, L. (2005). International Linkage and Democratization. Journal of Democracy , 16 (3), 20-34.

Levitsky, S., \& Way, L. (2006). Linkage versus Leverage: rethinking the International Dimension of Regime Change. Comparative Politics, 38 (4), 379-400.

Lewis, P. (1996). Economic Reform and Political Transition in Africa: The Quest for a Politics of Development. World Politics , 49 (1), 92-129.

Lindberg, S. (2006). Democracy and Elections in Africa. Baltimore: Johns Hopkins University Press. 
Lindberg, S. (2009). Democratization by Elections: A New Mode of Transition. Baltimore: Johns Hopkins University Press.

Linz, J. (1978). The Breakdown of Democratic Regimes: Crisis, Breakdown, and Reequilibration. Baltimore: Johns Hopkins University Press.

Lipset, S. M. (1960). Political Man. Garden City, N.Y.: Doubleday.

Lipset, S. M. (1981). Political Man: The Social Basis of Politics. Baltimore: John Hopkins University Press.

Lipset, S. (1959). Some Social Requisites of Democracy: Economic Development and Political Legitimacy. The American Political Science Review , 53 (1), 69-105.

Lolojih, P. K. Enhancing Local Governance: the Efficacy of Bilateral Cooperation. Lusaka: University of Zambia: http://www.fiuc.org/iaup/sap/.

Mainwaring, S., \& Perez-Linan, A. (2008). Regime Legacies and Democratization: Explaining Variance in the Level of Democracy in Latin America, 1978-2004. Accessed on: bttp:/ / 74.125.155.132/scholar?q= cache:QOYbbI2Uf3 AJ:scholar.google.com/+Mainwaring+Linan+2 $008+\mho b l=e n d a s_{-} s d t=2000,1-36$.

Makumbe, J. (1998). Is there a Civil Society in Africa? International Affairs, 74 (2), 305-317.

Manning, C. (2005). Assessing African Party Systems after the Third Wave. Party Politics , 11 (6), $707-$ 727.

Martin, M. (1993). Neither Phoenix Nor Icarus: Negotiating Economic Reform in Ghana and Zambia, 1983-1992. In T. Callaghy, \& J. Ravenhill, Hemmed in: Responses to Africa's Economic Decline (pp. 130-157). New York: Columbia University Press.

Matlosa, K. (1997). The 1993 Elections in Lesotho and The Nature of the BCP Victory. African Journal of Political Science, 2 (1), 140-151. 
Mattes, R., \& Bratton, M. (2007). Learning about Democracy in Africa: Awareness, Performance, and Experience. American Journal of Political Science , 51 (1), 192-217.

Mcguire, J. (2006). Basic Health Care Provision and Under-5 Mortality: A Cross-National Study of Developing Countries. World Development, 34 (3), 405-425.

Meebelo, H. (1986). African Proletarians and Colonial Capitalism. The Origins of Growth and Struggles of the Zambian Labour Movement to 1964. Lusaka: Kenneth Kaunda Foundation.

Meltzer, A. H., \& Richard, S. (1981). A Rational Theory of the Size of Government. The Journal of Political Economy, 89 (5), 914-927.

Meyns, P. (2002). Cape Verde: An African Exception. Journal of Democracy, 13 (3), 153-165.

Milimo, J. (1991). The Eastern Province of Zambia. In R. Celis, J. Milimo, \& S. Wanmali, Adopting Improved Farm Technology: A Study of Smallholder Farmers in Eastern Province, Zambia (pp. 7-20). Washington D.C.: International Food Policy Research Institute.

Morrison, M. (2004). Political Parties in Ghana through Four Republics: A Path to Democratic Consolidation. Comparative Politics, 36 (4), 421-442.

Mukwena, R. (1999). Building the Institutional Capacity of Local Authorities in Zambia in the Third Republic: An Assessment. African Administrative Studies , 53, 105-131.

Mukwena, R. (2001). Situating Decentralisation in Zambia in a Political Context. Report for African Training and Research Centre in Administration for Development.

Ndikumana, L. (1998). Institutional Failure and Ethnic Conflicts in Burundi. African Studies Review, 41 (1), 29-47.

Nelson, J. (2007). Elections, Democracy, and Social Services. Studies in Comparative International Development, 41 (4), 79-97.

Nelson, J., \& Eglinton, S. (1992). Encouraging Democracy: What Role for Conditioned Aid? Washington D.C.: Overseas Development Council. 
Network, A. (2006). Citizens and the State in Africa: New results from Afrobarometer Round 3.

Afrobarometer Working Papers.

Nie, N., Junn, J., \& Stehlik-Barry, K. (1996). Education and Democratic Citizenship in America. Chicago: University of Chicago Press.

Nohlen, D., Krennerich, M., \& Thibaut, B. (1999). Elections and Electoral Systems in Africa. In Elections in Africa: A Data Handbook. Oxford: Oxford University Press.

Nooruddin, I., \& Simmons, J. (2009). Openness, Uncertainty, and Social Spending: Implications for the Globalization - Welfare State Debate. International Studies Quarterly, Forthcoming.

Nordlund, P. (1996). Organizing the Political Agora. Dominatino and Democratization in Zambia and Zimbabwe. University of Uppsala: Unpublished PhD Dissertation.

Nwajiaku, K. (1994). The National Conferences in Benin and Togo Revisited. The Journal of Modern African Studies (32), 429-447.

Nyang'oro, J. (1996). Critical Notes on Political Liberalization in Africa (Brill). Journal of Asian and African Studies, 31 (1/2), 112-124.

Omgba, L. D. (2009). On the Duration of Political Power in Africa: The Role of Oil Rents. Comparative Political Studies, 42 (3), 416-436.

Paris, R. (2004). At War's End: Building Peace After Civil Conflict. New York: Cambridge University Press.

Paris, R. (1997). Peacebuilding and the Limits of Liberal Internationalism. International Security, 22 (2), 54-89.

Partenariat pour le Developpement Municipal (PDM). (2007). Decentralization in Zambia. http:/ / www.google.de/url?sa=t\&rct=j\&q=zambia $\% 20$ decentralisation $\% 20$ donors\&source= web\&cd=10\&ved=0CHoQFjAJ\&url=http $\% 3 \mathrm{~A} \% 2 \mathrm{~F} \% 2 \mathrm{Fwww}$. pdmnet.org $\% 2$ Ffiches_pays 
\%2FZambia\%2520_Sept07_.pdf\&ei=67uhTvb2AYPAswbn_OnmAg\&usg=AFQjCNFqpe EnmikdyE0W21ChLxTeb4k1pA\&sig2=ldy97_M49.

Pazzanita, A. G. (1999). Political Transition in Mauritania: Problems and Prospects. Middle East Journal, 53 (1), 44-58.

Pitcher, A., Moran, M., \& Johnston, M. (2009). Rethinking Patrimonialism and Neopatrimonialism in Africa. African Studies Review, 52 (1), 125-156.

Posner, D. (2004). Measuring Ethnic Fractionalization in Africa. American Journal of Political Science, 48 (4), 849-863.

Posner, D. (2007). Regime Change and Ethnic Cleavages in Africa. Comparative Political Studies , 40 (11), 1302-1327.

Posner, D., \& Young, D. (2007). The Institutionalization of Political Power in Africa. Journal of Democracy, 18 (3), 126-140.

Prempeh, K. (2008). Presidents Untamed. Journal of Democracy, 19 (2), 109-123.

Przeworski, A., Alvarez, M., Cheibub, J. A., \& Limongi, F. (2000). Democracy and Development: Political Institutions and Material Well-Being in the World, 1950-1990. Cambridge: Cambridge University Press.

Putnam, R. (1992). Making Democracy Work: Civil Traditions in Modern Italy. Princeton: Princeton University Press.

Putnam, R., Leonardi, R., \& Nanetti, R. (1993). Making Democracy Work: Civil Traditions in Modern Italy. Princeton: Princeton University Press.

Quaye, M. (1995). The Ghanaian Elections of 1992--A Dissenting View. African Affairs, 94. Rakner, L. (2003). Political and Economic Liberalisation in Zambia 1991-2001. Stockholm: Elanders Gotab. 
Rakner, L. (2002). Trade Unions in Processes of Democratisation. A Study of Party Labour Relations in Zambia. Chr. Michelsen Institute Report (6), available at: http://hdl.handle.net/10202/378.

Rakner, L. (1992). Trade Unions in Processes of Democratization: A Study of Party Labour Relations in Zambia. Chr. Michelsen Institue. Department of Social Science and Development.

Rakner, L., \& Svasand, L. (2004). From Dominant to Competitive Party System: The Zambian Experience 1991-2001. Party Politics, 10 (1), 49-68.

Reyntjens, F. (1993). The Proof of the Pudding is in the Eating: the June 1993 Elections in Burundi. The Journal of Modern African Studies (31), 563-583.

Roessler, P. (2005). Donor-Induced Democratization and the Privatization of State Violence in Kenya and Rwanda. Comparative Politics, 37 (2), 207-227.

Rose, R., Mishler, W., \& Haerpfer, C. (1998). Democracy and Its Alternatives: Understanding Post Communist Socieities. Baltimore: Johns Hopkins University Press.

Ross, M. (2001). Does Oil Hinder Democracy? World Politics , 53 (April), 325-361.

Ross, M. (2006). Is Democracy Good for the Poor? American Journal of Political Science , 50 (4), 860 874.

Ross, M. (Forthcoming). The Curse of Oil Wealth: Dataset.

Rudra, N., \& Haggard, S. (2005). Globalization, Democracy and Effective Welfare Spending in the Developing World. Comparative Political Studies, 38 (9), 1015-1049.

Sachikonye, L. (1990). The 1990 Zimbabwe Elections: A Post-Mortem. Review of African Political Economy (48), 92-99.

Saine, A. (2002). Post-Coup Politics in the Gambia. Journal of Democracy , 13 (4), 167-172.

Sandbrook, R. (2000). Closing the Circle: Democratization and Development in Africa. New York: St. Martin's Press. 
Sandbrook, R. (1996). Transitions without Consolidation in six African cases. Third World Quarterly, $17(1), 69-87$.

Schedler, A. (2002). Elections without Democracy: The Menu of Manipulation. Journal of Democracy, $13(2), 36-50$.

Sen, A. (1999). Democracy as a Universal Value. Journal of Democracy, 10 (3), 3-7.

Shandra, J., Nobles, J., London, B., \& Williamson, J. (2004). Dependency, Democracy and Infant Mortality: A Quantitative, Cross-National Analysis of Less Developed Countries. Social Science and Medicine , 59, 321-333.

Shettima, K. A. (1993). Structural Adjustment and the Student Movement in Nigeria. Review of African Political Economy (56), 83-91.

Sisk, T., \& Reynolds, A. (1999). Elections and Conflict Management in Africa. Washington D.C.: Endowment of the United States Institute of Peace.

Smoke, P. (2003). Decentralisation in Africa: Goals, Dimensions, Myths, and Challenges. Public Administration and Development (23), 7-16.

Southall, R. (1994). The 1993 Lesotho Election. Review of African Political Economy , 21 (59), 110-118. Stapenhurst, R. (2008). The Legislature and the Budget. In R. Stapenhurst, R. Pelizzo, D. Olson, \& L. von Trapp, Legislative Oversight and Budgeting: A World Perspective (pp. 51-65). Washington D.C. : World Bank.

Stasavage, D. (2005). Democracy and Education Spending in Africa. American Journal of Political Science , 49 (2), 343-358.

Stith, C. (2005). A Survey of American Media Coverage of African Democracies: 1994 -2004. The African Publications Archives Research Center (pp. 1-14). Johannesburg: African Presidential Roundtable .

Taylor, I. (2009). China's New Role in Africa. Boulder: Lynne Reinner Publishers. 
Tommasi, M., \& Weinschelbaum, F. (2007). Centralization Vs. Decentralization: A Principle-Agent Analysis. Journal of Public Economic Theory, 9 (2), 369-389.

Tordoff, W., \& Young, R. (1994). Decentralisation and Public Sector Reform in Zambia. Journal of Southern African Studies, 20 (2), 285-299.

Tripp, A. M. (2010). Museveni's Uganda: Paradoxes of Power in a Hybrid Regime. Boulder CO: Lynne Rienner Publishers.

Tull, D. (2006). China's Engagement in Africa: Scope, Significance and Consequences. The Journal of Modern African Studies , 44 (3), 459-479.

Uvin, P. (1993). 'Do as I say, not as I do': The Limits of Political Conditionality. The European Journal of Development Research , 5 (1), 63-84.

Uvin, P. (1999). Ethnicity and Power in Burundi and Rwanda: Different Paths to Mass Violence. Comparative Politics, 31 (3), 253-271.

van de Walle, N. (2002). Elections without Democracy: Africa's Range of Regimes. Journal of Democracy , 13 (2), 66-80.

van de Walle, N. (2003). Presidentialism and Clientelism in Africa's Emerging Party Systems. The Journal of Modern African Studies , 41 (2), 297-321.

Vener, J. (2000). Prompting Democratic Transitions from Abroad: International Donors and Multipartyism in Tanzania. Democratization, 7 (4), 133-163.

Vener, J. (2000). Prompting Democratic Transitions from Abroad: International Donors and Multipartyism in Tanzania. Democratization, 7 (4), 133-163.

Venter, D. (2003). Democracy and Multiparty Politics in Africa: Recent Elections in Zambia, Zimbabwe, and Lesotho. Eastern Africa Social Science Research Review, 19 (1), 1-39.

VonDoepp, P. (2005). The Problem of Judicial Control in Africa's Neopatrimonial Democracies: Malawi and Zambia. Political Science Quarterly, 120 (2), 275-301. 
Widner, J., \& Mundt, A. (1998). Researching Social Capital in Africa. Africa: Journal of the International African Institute , 68 (1), 1-24.

Wiseman, J. (1998). The Gambia: From Coup to Elections. Journal of Democracy, 9 (2), 64-75.

Witfield, L. (2009). 'Change for a Better Ghana': Party Competition, Institutionalization and Alternation in Ghana's 2008 Elections. African Affairs , 108 (433), 621-641.

Wright, J. (2009). How Foreign Aid Can Foster Democratization in Authoritarian Regimes. American Journal of Political Science, 53 (3), 552-571.

Young, C. (1976). The Politics of Cultural Pluralism. Madison: University of Wisconsin Press.

Zambia, R. o. (2006). (FNDP) Republic of Zambia's Fifth National Development Plan.

http://www.undp.org.zm/joomla/attachments/033_zambia_fndp.pdf?8e2474a80d13c9785 $641 \mathrm{fc} 2923161380=$ obtvvjhb. 